\title{
EVALUATION OF NUTRIENT RETENTION AND SEDIMENT DEPOSITION IN TWO URBAN STORMWATER RETENTION PONDS
}

\author{
by \\ Ryan Chad Ian Cheung \\ Honours Bachelor of Science in Environmental Science and Human Biology \\ University of Toronto, 2015 \\ A thesis \\ presented to \\ Ryerson University \\ in partial fulfillment of the \\ requirements for the degree of \\ Master of Applied Science \\ in the program of \\ Environmental Applied Science and Management
}

Toronto, Ontario, Canada, 2017

(C) Ryan Chad Ian Cheung, 2017 


\section{Author's Declaration}

I hereby declare that I am the sole author of this thesis. This is a true copy of the thesis, including any required final revisions, as accepted by my examiners.

I authorize Ryerson University to lend this thesis to other institutions or individuals for the purpose of scholarly research.

I further authorize Ryerson University to reproduce this thesis by photocopying or by other means, in total or in part, at the request of other institutions or individuals for the purpose of scholarly research.

I understand that my thesis may be made electronically available to the public. 
Abstract

EVALUATION OF NUTRIENT RETENTION AND SEDIMENT DEPOSITION IN TWO URBAN STORMWATER RETENTION PONDS

\author{
Ryan Chad Ian Cheung \\ Master of Applied Science, 2017 \\ Environmental Applied Science and Management \\ Ryerson University
}

Stormwater ponds have been implemented in many municipalities to control urban runoff and retain pollutants, such as nutrients and suspended solids. Two stormwater ponds in Toronto, Ontario were evaluated for their ability to retain nutrients and suspended solids and were also used to investigate mechanisms by which stormwater ponds remove nutrient pollutants, including the importance of deposition and internal loading. Over the entire study period, Hydro Pond East (HEP) retained $1415 \mathrm{mg}$ of total suspended solids (TSS) and MAT retained $1127 \mathrm{mg}$ of TSS. Both Hydro East Pond (HEP) and Mattamy Rouge (MAT) were net exporters of phosphorus $(\mathrm{P})$ over the entire season, with $6.35 \mathrm{~mol}$ or $0.20 \mathrm{~kg}$ and $53.9 \mathrm{~mol}$ or $1.67 \mathrm{~kg}$ exported, respectively. HEP had net retention of $2672 \mathrm{~mol}$ or $37.4 \mathrm{~kg}$ of nitrogen (N) but MAT exported $264 \mathrm{~mol}$ or $3.7 \mathrm{~kg}$ of nitrogen over the entire study. This study has demonstrated that stormwater ponds have the ability to provide retention of nutrients and TSS, but their function may be enhanced as they may become exporters. However, the amount of nutrients exported was extremely low and may have been driven by the anomalously dry 2016 year in Toronto. Further research should be done on these same ponds to observe how they may perform under an anomalously wet year (e.g. 2017). There is a need for a future model to synthesize the data from literature on stormwater ponds to better understand their function to better help local water managers determine if these ponds are needed and how they may need to enhance their function. 


\section{Contributions of Authors}

The following list provides the names and responsibilities of the people who have contributed to the manuscript which is the basis of this thesis:

Ryan C. I. Cheung (Candidate): primary author of the manuscript and thesis, performed data collection and analyses

Dr. Vadim Bostan (Supervisor): provided the design and identification of the research undertaking, provided guidance on the method of analysis, reviewed and edited manuscipt Dr. Andrew Laursen (Supervisor): provided the design and identification of the research undertaking, provided guidance on the method of analysis, reviewed and edited manuscipt Aslam Hanief: assisted with data collection and analyses

Ramesh Lilwah: assisted with data collection 


\section{Acknowledgements}

I would like to express my sincerest gratefulness and appreciation to my co-supervisors, Dr. Vadim Bostan and Dr. Andrew Laursen, who have provided me with boundless support and guidance these past two years. The both of you have enriched me with a wealth of knowledge in your respected areas and have inspired me to pursue my research.

I am thankful to have worked with such a great research team and spent hours with in the field and in the laboratory. I am indebted to Aslam Hanief, who has been such a great mentor, laboratory companion, and friend. Without your countless help and advice, I do not think my thesis would have materialized. Ramesh Lilwah, I will never forget our time spent together on our long field days and in the laboratory, thank you for all the support you have given me throughout the past few years. To the laboratory technical staff, Karen Puddephatt, Liberty Victorio-Walz, and Miriam de Jong, thank you for allowing me to use all the analytical equipment I needed. I would also like to thank my laboratory volunteers, Verita Thirumal and Carmen Tran, for spending many hours helping out in the laboratory for my thesis.

This thesis would not have been possible without the City of Toronto, Toronto Water division's support and permission to conduct my research on their stormwater ponds.

Lastly, I would like to thank my friends and family for their support and encouragement over the years of university. My deepest gratitude goes to my parents and my grandparents for all their love, strength, and moral support as I pursued my educational career. Their confidence in me allowed me to persevere through these years. I owe everything I have achieved to them. Thank you. 


\section{Dedication}

I would like to dedicate my thesis to my Mom, Dad, and Grandparents, who have always been there for me with their love, endless support, and encouragement. 


\section{Table of Contents}

Author's Declaration ......................................................................................................................... ii

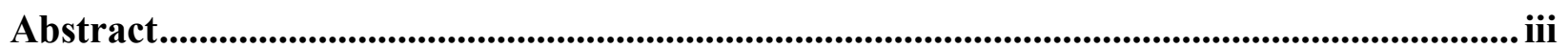

Contributions of Authors ..................................................................................................... iv

Acknowledgements ............................................................................................................................. V

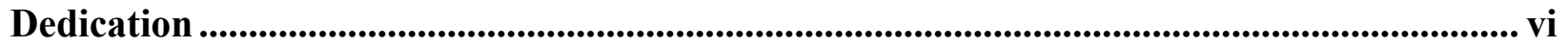

List of Tables ................................................................................................................ vii

List of Figures..........................................................................................................

List of Appendices.................................................................................................................... $x$

List of Abbreviations ................................................................................................................... xii

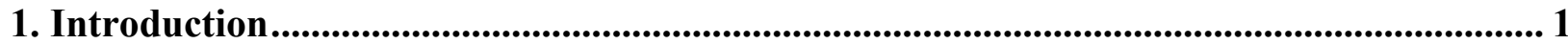

1.1 Overview.............................................................................................................................................1

1.2 Hydrologic Effects of Urbanization ...............................................................................................2

1.3 Historical Development of Stormwater Ponds...................................................................................

1.4 Stormwater Ponds: Detention vs. Retention Ponds..............................................................................

1.5 Water Quality Parameters....................................................................................................................6

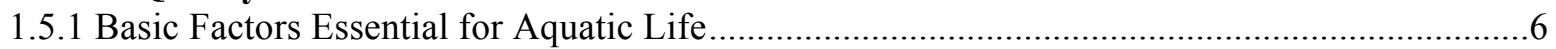

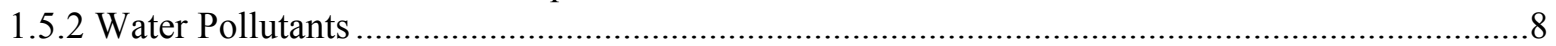

1.6 Stormwater Pond Performance for Suspended Solids and Nutrient Removal............................14

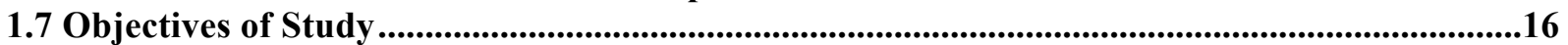

2. Evaluation of Nutrient Retention and Sediment Deposition in Two Urban Stormwater

Retention Ponds ....................................................................................................................................... 17

2.1 Introduction ..............................................................................................................................

2.2 Materials and Methods ..................................................................................................................21

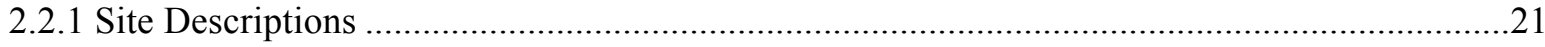

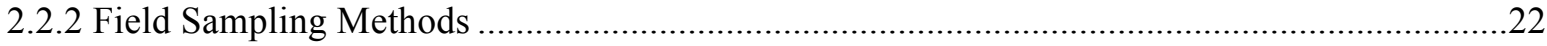

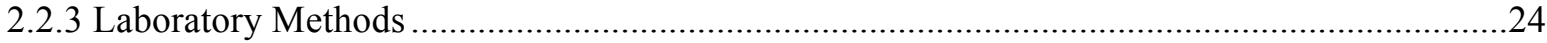

2.2.4 Statistical Analyses ………………………………………………………………………..... 27

2.3 Results and Discussion ..................................................................................................................27

2.3.1 Temperature and DO Concentrations.................................................................................27

2.3.2 Nutrient Concentrations ...................................................................................................29

2.3.2 Percent Retention of Nutrients \& Total Suspended Solids .....................................................34

2.3.3 Sediment Traps............................................................................................................

2.3.4 Nutrient Budget Model .............................................................................................. 42

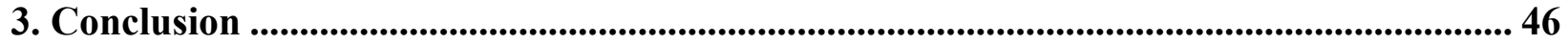

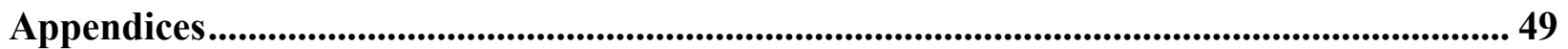

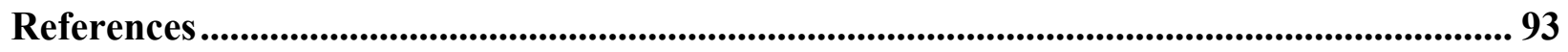




\section{List of Tables}

Table 1.1 Summary of selected water quality guidelines provided in Ontario's PWQO. (MOEE 1994)

Table 2.1 Characteristics of Hydro East and Mattamy Rouge stormwater ponds..................... 22

Table 2.2 Field monitoring and sampling schedule at Hydro East and Mattamy Rouge ponds... 22

Table 2.3 Summary of data comparison between study and previous studies on stormwater ponds. Values in parenthesis are concentration ranges observed. ................................ 30

Table 2.4 Analysis of covariance results for nutrient concentrations, comparing ponds with

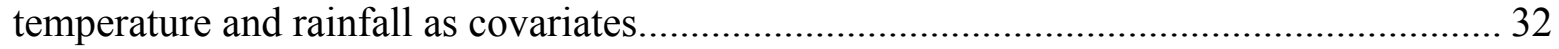

Table 2.5 Loading, export, and retention of TP, TN, and TSS in HEP and MAT..................... 40 


\section{List of Figures}

Fig. 1.1 The hydrologic cycle (Modified from Wetzel and Likens 1991)................................ 3

Fig. 1.2 Runoff hydrograph for pre- and post-development areas (Marsalek et al. 1992)............ 4

Fig. 1.3 Historical development of stormwater ponds (Reproduced from McCuen et al. 1983).... 5

Fig. 1.4 Vertical distribution of oxygen concentrations and temperature $(\theta)$ of an oligotrophic and a eutrophic lake during the four main seasons (Reproduced from Wetzel 2001)................ 8

Fig. 2.1 Map displaying the locations and proximity of Hydro East Pond and Mattamy Rouge

Pond in Toronto, Ontario, Canada. (ESRI base map, TRCA land use shapefile) ............... 21

Fig. 2.2 Map of the sampling points at Hydro East Pond and Mattamy Rouge Pond................ 23

Fig. 2.3 Temperature and Dissolved Oxygen (DO) concentrations measured at depths of $10 \mathrm{~cm}$ intervals from the pond surface to the pond bottom on June 15, 2016. a) HEP b) MAT.... 28

Fig. 2.4 Concentrations of nutrient constituents from composite samples in HEP and MAT and total precipitation during the two weeks prior to sampling date: a) total phosphorus, $b$ ) dissolved reactive phosphorus, c) ammonium, d) nitrate.

Fig. 2.5 Percent retention of nutrient constituents and TSS in HEP and MAT: a) total phosphorus, b) dissolved reactive phosphorus, c) ammonium, d) nitrate, e) total suspended solids.

Fig. 2.6 Sediment deposition rates $\left(\mathrm{mm} \mathrm{day}^{-1}\right)$ from sediment traps in HEP and MAT. 41

Fig. 2.7 Percent organic phosphorus in sediment collected from sediment traps in HEP and MAT. 42

Fig. 2.8 Nutrient budgets for HEP and MAT over the entire sampling season in 2016. 43 


\section{List of Appendices}

Appendix A: Map of Location and Proximity of Hydro East and Mattamy Rouge Ponds

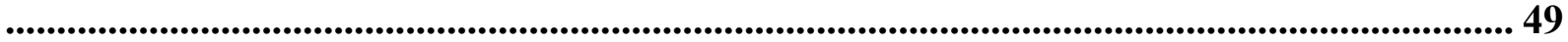

Appendix B: Site Drawing of Hydro East Pond....................................................................... 50

Appendix C: Site Drawing of Mattamy Rouge Pond ............................................................ 51

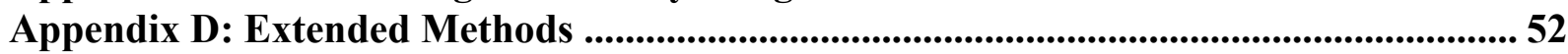

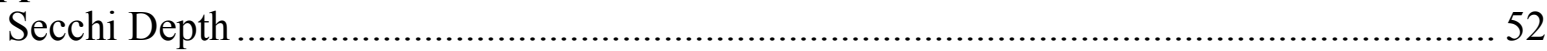

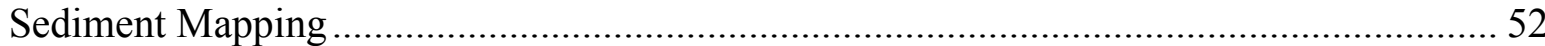

Analysis of Organic Matter in Sediment Samples ........................................................ 54

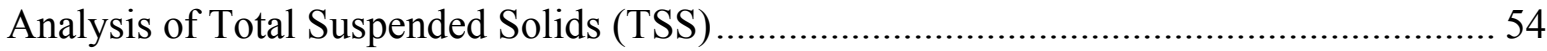

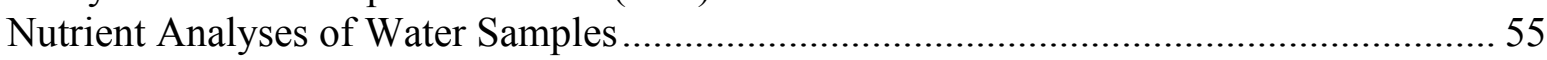

Extraction of Pore Water from Sediment Samples and Nutrient Analyses ....................... 57

Nutrient Analyses of Sediment Samples......................................................................... 58

Calculation for Concentrations of Nutrient Constituents in Sediment Samples.................. 60

Calculation for Conversion of Sediment Concentrations from $\mathrm{mg} \mathrm{kg}^{-1}$ to $\mathrm{mol} \mathrm{L}^{-1}$............ 60

Appendix E: Secchi Depth Measurements ...............................................................6 61

Appendix F: Depth of Water Column and Depth from Surface to Bottom of Sediment

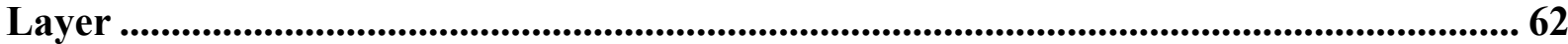

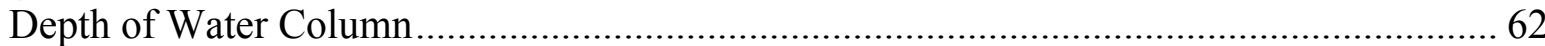

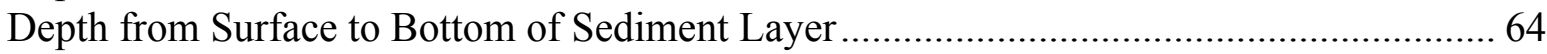

Appendix G: Temperature and Dissolved Oxygen (DO) Concentrations ......................... 65

Appendix H: Volume of Sediment Collected from Sediment Traps ................................. 66

Appendix I: Percent Organic Matter in Bottom Sediment................................................ 67

Appendix J: Percent Organic Matter in Sediment Collected from Sediment Traps ....... 68

Appendix K: Concentrations of TSS in Water Samples .................................................. 71

Appendix L: Mean Concentrations of TP in Water Samples ................................................ 72

Appendix M: Mean Concentrations of DRP in Water Samples..................................... 73

Appendix N: Mean Concentrations of Ammonium in Water Samples ............................ 74

Appendix O: Mean Concentrations of Nitrate in Water Samples ....................................... 75

Appendix P: Mean Concentrations of TIN in Water Samples .......................................... 76

Appendix Q: Retention of TSS and Nutrient Constituents in HEP and MAT ................. 77

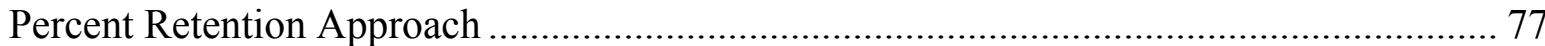

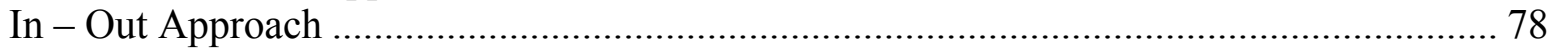

Appendix R: Mean Concentrations of TP from Bottom Sediment and Sediment Collected from Sediment Traps ........................................................................................................................ 79

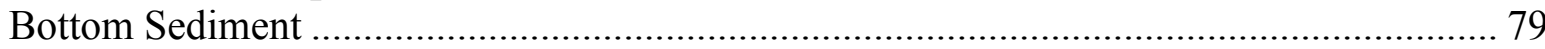

Sediment Collected from Sediment Traps ...................................................................... 79

Appendix S: Percentage of IP and OP in Bottom Sediment ............................................... 80

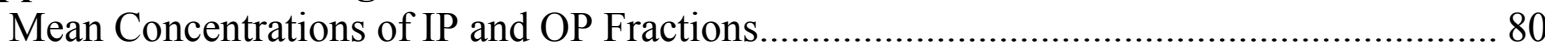

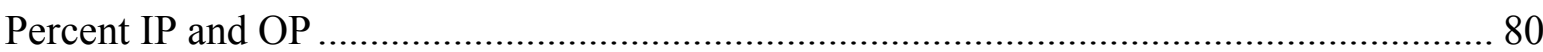

Appendix T: Percentage of IP and OP in Sediment Collected from Sediment Traps..... 81

Mean Concentrations of IP and OP Fractions............................................................ 81

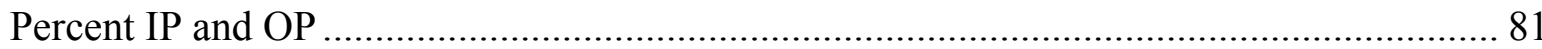


Appendix U: Mean Concentrations and Percentage of BAP in Bottom Sediment and in Sediment Collected from Sediment Traps.............................................................................. 82

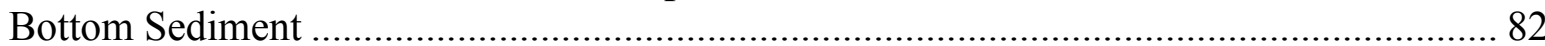

Sediment Collected from Sediment Traps ..................................................................... 82 Appendix V: Mean Concentrations of TN in Bottom Sediment and in Sediment Collected

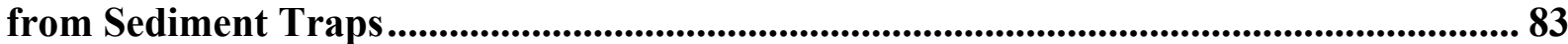

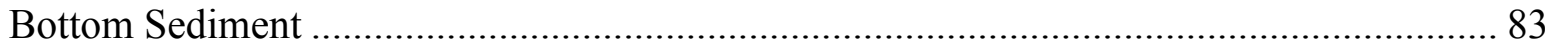

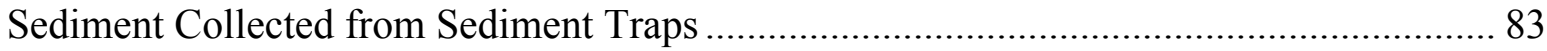

Appendix W: Nutrient Loading and Retention Calculations in HEP and MAT ............. 84

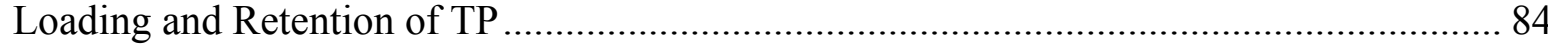

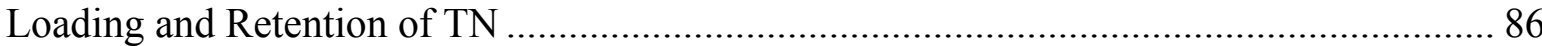

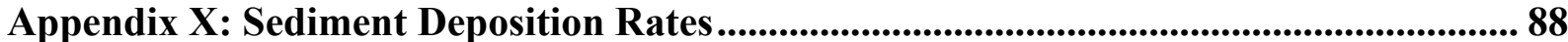

Appendix Y: Weather Data (Daily Total Precipitation and Average Temperature) ....... 89 


\section{List of Abbreviations}

\begin{tabular}{ll} 
DO & Dissolved Oxygen \\
DRP & Dissolved Reactive Phosphorus \\
HEP & Hydro East Pond \\
MAT & Mattamy Rouge Pond \\
N & Nitrogen \\
NURP & National Urban Runoff Program \\
OMOE & Ontario Ministry of the Environment \\
OMOEE & Ontario Ministry of the Environment \& Energy \\
P & Phosphorus \\
PAHs & Polycyclic Aromatic Hydrocarbons \\
PWQO & Provincial Water Quality Objectives \\
TSGS & United States Geological Survey \\
TIN & Total Inorganic Nitrogen \\
TN & Total Nitrogen \\
TP & Total Phosphorus \\
\hline TRE & Toronto and Region Conservation \\
\hline Thited States Environmental Protection Agency
\end{tabular}




\section{Introduction}

\subsection{Overview}

As the population around the world continues to increase, there is a rapid trend toward urbanization. It has been estimated that $54 \%$ of the world population currently resides in urban areas and this is projected to increase to $66 \%$ by 2050 (United Nations 2014). Much of the land surface has been converted for human use resulting in a variety of environmental impacts related to food production, freshwater and forest resources, climate and air quality, and infectious diseases (Foley et al. 2005). One of the major consequences of urbanization is it changes hydrological pathways. Under natural ground cover conditions in rural areas, 70 to $90 \%$ of rainfall infiltrates into the ground or is evapotranspired (Arnold and Gibbons 1996; Paul and Meyer 2001). However, due to the conversion of natural land into hardened, impervious surfaces (such as rooftops and streets) during urbanization, it has been estimated that up to $80 \%$ of precipitation may end up as direct surface runoff in high density residential areas (Arnold and Gibbons 1996; Paul and Meyer 2001).

Stormwater ponds have been implemented in many municipalities since the 1980s (Debo and Reese 1995) as a method to mitigate the potential for flooding and to remove pollutants, such as suspended solids, particulate nutrients, heavy metals, and hydrocarbons, from runoff in urbanized areas (McCuen et al. 1983; Marsalek et al. 1992; Marsalek and Marsalek 1997). However, there has been a lack of studies in the literature on the nutrient removal performance of stormwater ponds. This presents a major problem as high nutrient levels in receiving waters will allow for an increase in primary production and may lead to a eutrophic aquatic system 
(Wetzel 2001). It is imperative to have performance data of stormwater ponds to know whether they are performing as desired and if not, what can be done to improve it.

Despite the lack of studies, all studies showed some removal of nutrients and agreed that removal was due to the adsorption to particulate matter, which settled to the bottom of the pond, and by biological uptake (Wu et al.1996; Comings et al. 2000; Mallin et al. 2002; Winston et al. 2013). However, all of the studies reviewed have only analyzed nutrients in the water column and none have analyzed the process of sedimentation in removing nutrients from the water column. The role of sediments can have great influence on the phosphorus and nitrogen cycling (Wetzel 2001; Golterman 2004) in stormwater ponds and it is important to include it as part of all limnologic studies.

The purpose of this study was to evaluate the function and ecosystem services provided by two wet retention ponds in an urban area, constructing a near-annual budget of nutrient inputs, outputs, and sedimentation. The results from this study will allow for the comparison and addition to the relatively few data available on stormwater retention ponds to advance the understanding of how these systems function in nutrient and sediment removal, and how environmental conditions and design/application may affect their performance in delivering these services.

\subsection{Hydrologic Effects of Urbanization}

The hydrological cycle describes the cyclical movement of water between the atmosphere, land, and oceans. The three main processes of the cycle are precipitation, evaporation, and surface and groundwater runoff (Fig. 1.1). 


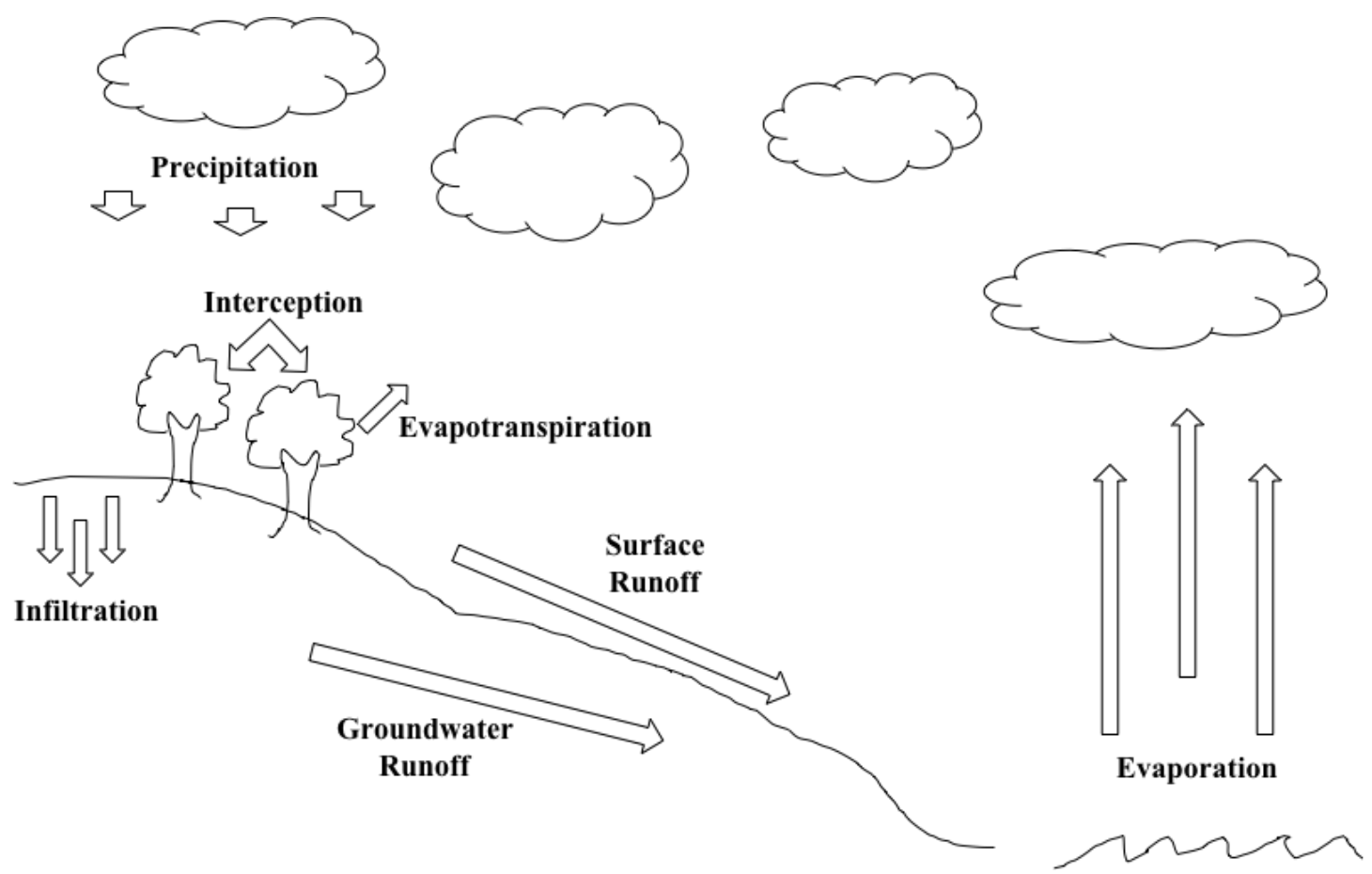

Fig. 1.1 The hydrologic cycle (Modified from Wetzel and Likens 1991).

Water from precipitation may be intercepted by plants, infiltrate into the ground or flow over and under the land surface. Under natural ground cover conditions, 70 to $90 \%$ of rainfall is infiltrated into the ground or evapotranspired (Davis and McCuen 2005). However, urbanization converts natural land into hardened, impervious surfaces (such as rooftops and streets) which result in major changes to the hydrological pathways. It has been estimated that up to $80 \%$ of precipitation may end up as direct surface runoff in high density residential areas (Davis and McCuen 2005). This causes higher and more rapid peak runoff flow rates (Fig. 1.2) and, as a result, increases the potential for flooding (McCuen et al. 1983; Lazaro 1990; Marsalek et al. 1992). 


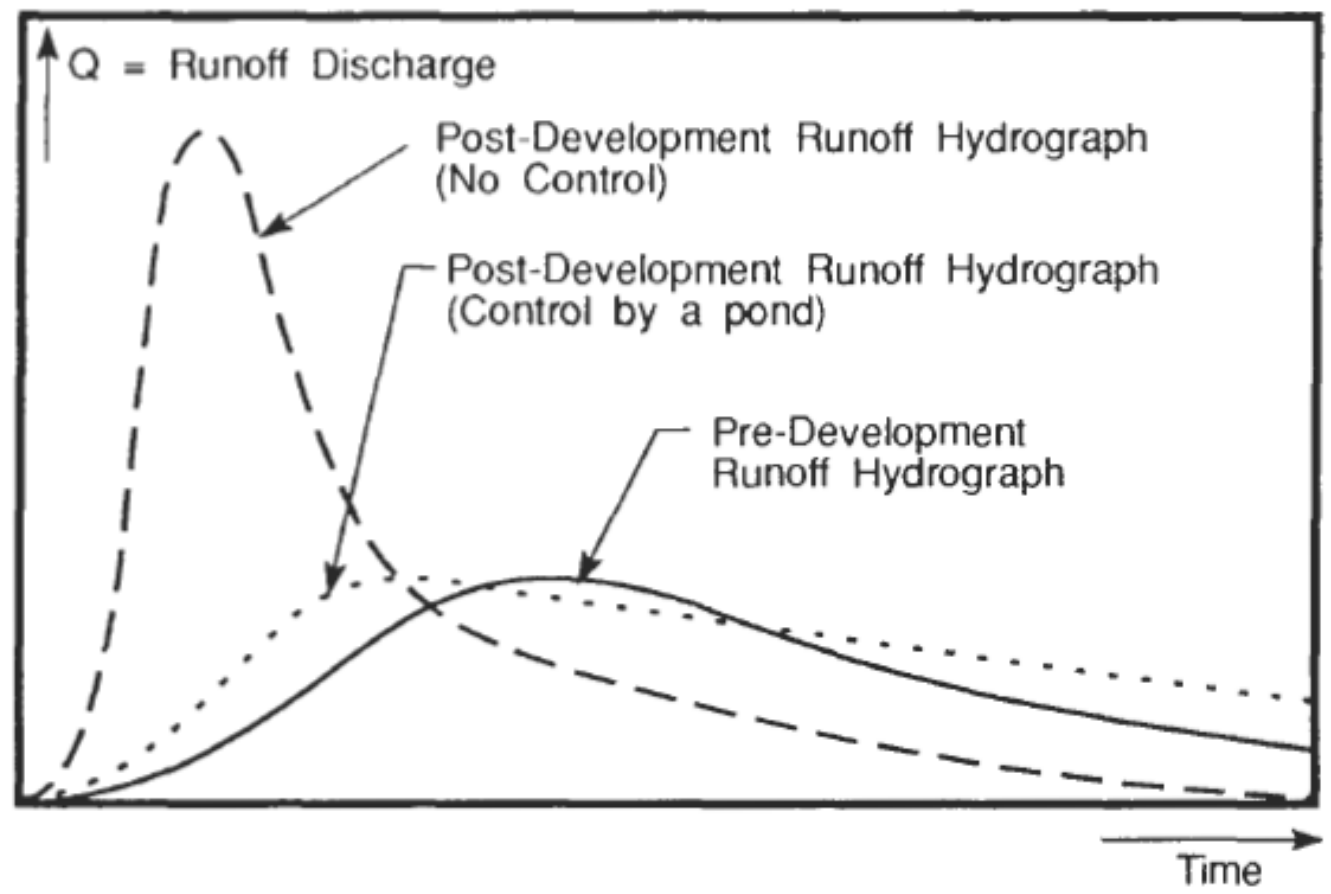

Fig. 1.2 Runoff hydrograph for pre- and post-development areas (Marsalek et al. 1992).

\subsection{Historical Development of Stormwater Ponds}

In response to the growing concern over localized flooding due to the development of urban areas, municipalities in the 1970s recognized the importance and need for on-site and regional stormwater detention and retention basins (Debo and Reese 1995). Initially, these detention and retention basins were viewed to be more economical and more efficient than traditional stormwater conveyance systems at managing stormwater quantity (McCuen et al. 1983; Debo and Reese 1995) (Fig. 1.3). Stormwater ponds can control the quantity of runoff by reducing and delaying peak flows and releasing runoff at rates close to predevelopment peak flow (Marsalek et al. 1992) (Fig. 1.2). Municipalities soon also recognized their ability to provide a community with improved aesthetics and recreational amenities (McCuen et al. 1983; OMOE 2003). During the 1980s the National Urban Runoff Program (NURP) and various other researchers reported that not only do the higher volumes of runoff increase the risk of 
flooding, but they also become a vehicle for various pollutants to be transported into nearby receiving waters (USEPA 1983; Novotny et al. 1985). These reports led to the development of regulations to reduce and control pollutants in urban stormwater runoff in the 1990s (Debo and Reese 1995; Burns et al. 2011).

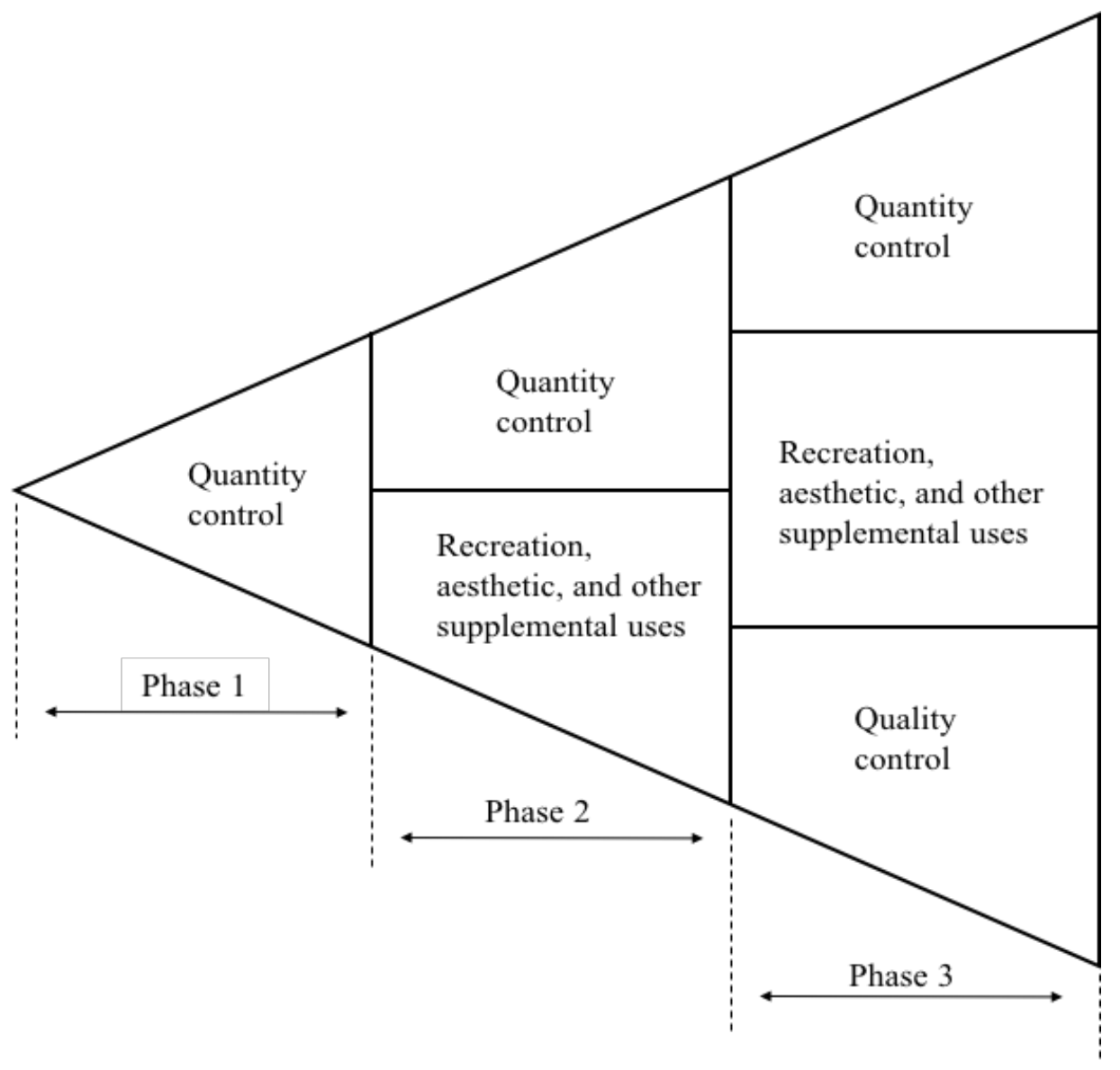

Fig. 1.3 Historical development of stormwater ponds (Reproduced from McCuen et al. 1983).

\subsection{Stormwater Ponds: Detention vs. Retention Ponds}

Retention ponds, also known as wet ponds, can be thought of as small, shallow man-made lakes which contain a permanent pool of water (Debo and Reese 1995). Detention ponds, also known as dry ponds, do not contain a permanent pool of water and are dry except for a period of time after a storm (Stanley 1996). Both retention and detention ponds collect runoff from 
storms as temporary storage facilities and slowly release it into receiving bodies of water

(McCuen et al. 1983). Retention ponds are the most common stormwater management facility used in Ontario and have proven to be the most effective practice in Eastern United States as well (Debo and Reese 1995; OMOE 2003). For the purposes of this study, "stormwater ponds" refer to "retention ponds", or "wet ponds".

\subsection{Water Quality Parameters}

In 1994, the Ontario Ministry of Environment and Energy released the Provincial Water Quality Objectives (PWQO) to ensure that the water quality in Ontario is acceptable for aquatic life and recreation uses. The PWQO provides a long list of guidelines for various chemicals and parameters (Table 1.1).

Table 1.1 Summary of selected water quality guidelines provided in Ontario's PWQO (MOEE 1994).

\begin{tabular}{|lc|lc|}
\hline \multicolumn{1}{|c|}{ Parameter } & \multicolumn{1}{c|}{ Value } & \multicolumn{1}{c|}{ Parameter } & Value \\
\hline $\mathrm{pH}$ & $5.0-9.0$ & E. coli & $<100 / 100 \mathrm{~mL}$ \\
Ammonia (un-ionized) & $<0.02 \mathrm{mg} / \mathrm{L}$ & Dissolved Oxygen & $>5.0 \mathrm{mg} / \mathrm{L}$ \\
Nitrate & $<10 \mathrm{mg} / \mathrm{L}$ & Total Phosphorus & $<0.01 \mathrm{mg} / \mathrm{L}$ \\
\hline
\end{tabular}

\subsubsection{Basic Factors Essential for Aquatic Life}

In order to maintain a healthy aquatic ecosystem, there are three main important parameters: dissolved oxygen, $\mathrm{pH}$, and temperature (Wetzel 2001; Davis and McCuen 2005).

\subsubsection{Dissolved Oxygen (DO) and Temperature}

Dissolved oxygen is the most vital factor in aquatic systems as it is required by all aerobic aquatic organisms. However, there is a limit as to how much oxygen can be dissolved in water. The solubility of oxygen is a function of temperature and increases with decreased temperature 
(Benson and Krause 1980; Mortimer 1981). Dependent on the temperature and salinity, it has been found that water can hold a maximum of 8 to $14 \mathrm{mg} \mathrm{L}^{-1}$ of oxygen (Benson and Krause 1980; Mortimer 1981). Studies have shown that fish become stressed when exposed to DO levels under $5 \mathrm{mg} \mathrm{L}^{-1}$ (Reynolds and Thompson 1974; Kramer 1987; Matthews and Berg 1997).

For oxygen to reach an equilibrium between the atmosphere and water, there must be circulation in the water column of a lake (Wetzel 2001). Wetzel (2001) illustrates the vertical distribution of oxygen and temperature of an oligotrophic (low nutrient inputs with low organic production) and eutrophic (high nutrient loading with high organic production) lake during the four main seasons (Fig. 1.4). During the spring and fall seasons, the lakes are completely saturated with oxygen as there is complete mixing within the lake resulting from no thermal stratification. During the summer season, a thermal stratification develops in both lakes, where the upper epilimnion layer has higher temperatures from exposure to the sun than the lower hypolimnion layer. However, contrasting vertical oxygen profiles are observed between oligotrophic and eutrophic lakes. The amount of deposition of organic matter from the epilimnion into the hypolimnion influences the intensity of oxidative processes within the lower layer (Wetzel 2001). As there is low productivity and organic production in oligotrophic lakes, the oxygen concentration distribution within the lake is dependent on temperature, where oxygen concentrations increase as temperature decreases with depth. In contrast, due to high organic production, and subsequently deposition, in eutrophic lakes, the hypolimnion is anoxic as oxygen is depleted rapidly from oxidation processes. 


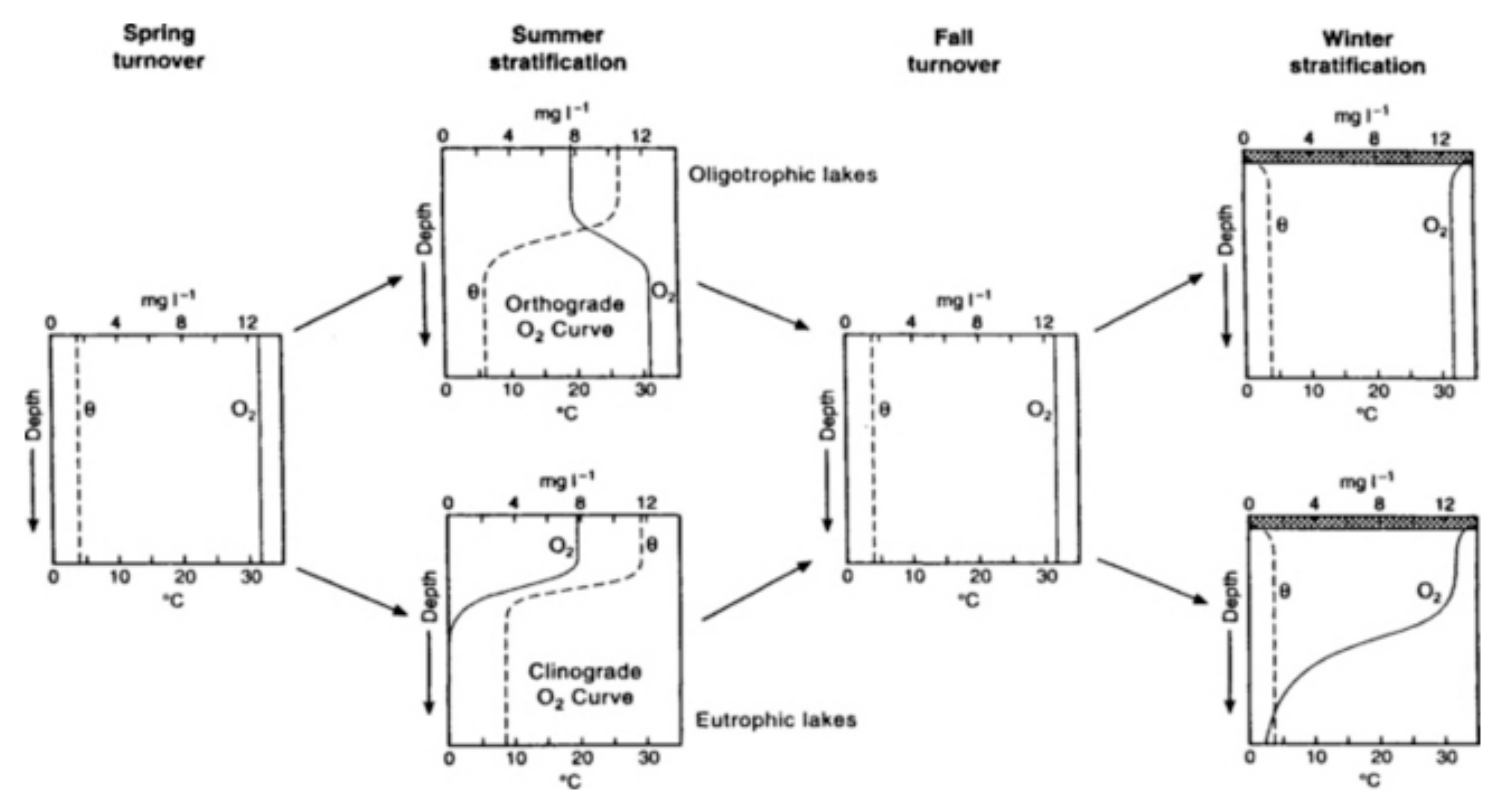

Fig. 1.4 Vertical distribution of oxygen concentrations and temperature $(\theta)$ of an oligotrophic and a eutrophic lake during the four main seasons (Reproduced from Wetzel 2001).

\subsubsection{2 $\mathrm{pH}$}

The optimal $\mathrm{pH}$ for most aquatic organisms lies between 6 and 8 . The $\mathrm{pH}$ of water can be influenced by various biological processes. Photosynthetic activity in the trophogenic zone, the upper portion of lake where enough light penetrates through for photosynthesis, consumes carbon dioxide $\left(\mathrm{CO}_{2}\right)$ and, as a result, increases $\mathrm{pH}$ (Wetzel 2001). Respiratory generation of $\mathrm{CO}_{2}$, heterotrophic degradation of organic matter, microbial methane fermentation, nitrification of ammonia, and sulfide oxidation throughout the water column and sediments can decrease $\mathrm{pH}$ in a lake (Wetzel 2001).

\subsubsection{Water Pollutants}

Sources of pollution in stormwater runoff can result from wet and dry atmospheric deposition, litter and dirt from streets, vegetation and organic residues, overflow from sanitary sewers, lawn and agricultural fertilizers, animal droppings, and materials from other activities 
(Novotny et al. 1985; Whipple et al. 1987; Makepeace et al. 1995). Some of the major pollutants in stormwater runoff include: suspended solids, nutrients, heavy metals, polycyclic aromatic hydrocarbons (PAHs), and pesticides (USEPA 1983; Makepeace et al. 1995; Mayer et al. 1996; Characklis and Wiesner 1997; Lee et al. 1997; Waschbusch et al. 1999; Davis et al. 2001; Weston et al. 2009).

\subsubsection{Suspended Solids}

Suspended solids are the most common pollutant found in urban stormwater runoff (USEPA, 1999; Davis and McCuen 2005). These solids are composed of fine particulate matter of clay, silt, vegetation, and bacteria (Davis and McCuen 2005) which are picked up during runoff flow and held in the water column of a water body by turbulence (Bilotta and Brazier 2008). Suspended solids can also be produced within the pond by growth of algae and bacteria, and may be a mechanism of nutrient (and other pollutant) removal from water through biological uptake. The accumulation of suspended solids can induce various physical, chemical, and biological changes in a water body. High levels of suspended solids can increase turbidity and subsequently decrease the amount of light penetration through the water column required by photosynthetic organisms, trigger temperature changes, and cause infilling of the reservoir which may result in a loss of habitat for fish and bottom-dwelling organisms (Davis and McCuen 2005; Bilotta and Brazier 2008). Suspended solids can also act as a medium for the transport, storage, and release of contaminants, such as heavy metals, PAHs, pesticides, and nutrients (Dawson and Macklin 1998; Russell et al. 1998; Kronvang et al. 2003; Golterman 2004). Suspended solids containing high organic matter may also deplete dissolved oxygen concentrations within the water column from in situ decomposition (Wetzel 2001; Bilotta and Brazier 2008). 


\subsubsection{Nutrients - Phosphorus}

Phosphorus is the least abundant nutritional component in most fresh water systems, and is commonly the limiting nutrient for biological productivity (Schindler 1974). However, urbanization has allowed phosphorus compounds to enter receiving water bodies through runoff, creating eutrophic conditions. Some major sources of phosphorus in runoff include excess fertilizers, cleaning detergents, decay of vegetation, animal and wastes (Waschbusch et al. 1999; Wetzel 2001; Davis and McCuen 2005).

Orthophosphate $\left(\mathrm{PO}_{4}^{-3}\right)$ is the most basic inorganic form of phosphorus found in water. Over $90 \%$ of phosphorus in fresh water are organic phosphates and cellular compounds in organisms which are adsorbed to inorganic and dead material (Wetzel 2001). When analyzing total phosphorus content in water, it consists of phosphorus in two compartments: particulate and dissolved (Juday et al. 1927). Particulate phosphorus can be found in both inorganic and organic forms. Particulate inorganic phosphorus can be in forms of mineral phases adsorbed to abiotic or biotic particles and intercellular storage compounds as orthophosphate, pyrophosphate and polyphosphate (Yoshimura et al. 2007). Particulate organic phosphorus includes phosphorus found in living and detritus organic molecules. Dissolved phosphorus can be found in forms of orthophosphate, polyphosphates, organic colloids, and low-molecularweight phosphate esters. It has been demonstrated by Vollenweider (1968) that lake productivity generally increases with increasing amounts of total phosphorus. Lakes are considered eutrophic when total phosphorus concentrations are between 30-100 $\mu \mathrm{g} \mathrm{L}^{-1}$ (Vollenweider 1968).

A major component of the phosphorus cycle in natural waters is the exchange of phosphorus between sediments and the overlying water. The main mechanisms by which 
phosphorus can be deposited into the sediment: settling of imported material, adsorption or precipitation with inorganic compounds, settling of allochtonous and autochthonous organic matter, uptake by algal or microbial communities and settling to sediment as detritus (Boström et al. 1988). Although there is commonly a net movement of phosphorus into sediments, several physical, chemical, and biological conditions dictate whether the sediments become a source or sink for phosphorus. It has been shown in past studies (Einsele 1936, 1938; Mortimer 1942) that under oxic condition, lake sediments retain phosphorus by precipitating iron (III) oxyhydroxides, which have the ability to adsorb phosphorus. Anoxic conditions will release phosphorus due to the reductive dissolution of iron (III) oxyhydroxides and subsequent dissolution of previously bound phosphorus. However, there has been discussion that the release of phosphorus from sediments is not only dependent on dissolved oxygen levels but a balance between the sedimentation of organic matter, phosphorus, iron, and sulfide production by diagenetic processes within in the sediment (Golterman 2001; Gächter and Müller 2003). For example, some microorganisms may catalyze the oxidation of iron (II) under oxic or anoxic conditions and also the reduction of iron (III) in anoxic environments (Kappler and Straub 2005). If microorganisms present in the sediment can catalyze the oxidation iron (II) to iron (III), this may allow for more precipitation of iron (III) oxyhydroxides to absorb phosphorus

\subsubsection{Nutrients - Nitrogen}

Nitrogen can be present in water in a number of different forms: dissolved molecular $\mathrm{N}_{2}$, organic compounds from amino acids, amines, and proteins, recalcitrant humic compounds of low nitrogen content, ammonia $\left(\mathrm{NH}_{3}\right)$, nitrite $\left(\mathrm{NO}_{2}{ }^{-}\right)$, and nitrate $\left(\mathrm{NO}_{3}{ }^{-}\right)$(Wetzel 2001). Sources of nitrogen compounds in stormwater ponds include: atmospheric deposition, nitrogen fixation in the water and sediments, and from runoff containing nitrogen from fertilizers, animal wastes, 
and plant decay (Wetzel 2001; Davis and McCuen 2005). Similar to the trends found regarding the positive relationship between phosphorus and lake productivity, Vollenweider (1968) also showed a positive correlation between high productivity of algal populations and average concentrations of inorganic and organic nitrogen. Lakes are considered eutrophic when inorganic and organic nitrogen concentrations are between $0.5-1.5 \mathrm{mg} \mathrm{L}^{-1}$ and $0.7-1.2 \mathrm{mg} \mathrm{L}^{-1}$, respectively (Vollenweider 1968). Although Schindler (1974) later showed that phosphorus is the main driver of eutrophication, subsequent studies have shown that nitrogen can be limiting in some systems (Goldman 1981; Howarth and Cole 1985; Wurtsbaugh 1988) and in some cases, can also enhance the effect of any phosphorus addition (Elser and Kimmel 1985). A study by Elser et al. (2007) has shown that there is an increasing prevalence nitrogen and phosphorus limited systems and that the simultaneous addition of nitrogen and phosphorus can create a positive synergistic response of higher production levels.

Ammonia can be generated by biological reduction of nitrate, and as a primary end-product of the decomposition of organic matter by heterotrophic bacteria (Wetzel 2001). Ammonia occurs primarily as ammonium $\left(\mathrm{NH}_{4}{ }^{+}\right)$in water. In aerobic waters, ammonium concentrations are usually low as they can be readily assimilated by plants and commonly oxidized to nitrate via a two-step process $\left(\mathrm{NH}_{4}{ }^{+} \rightarrow \mathrm{NO}_{2}{ }^{-} \rightarrow \mathrm{NO}_{3}{ }^{-}\right)$, known as nitrification, by aerobic chemoautotrophic bacteria (Sharma and Ahlert 1977; Wetzel 2001). However, nitrate is a major pollutant in water bodies as excess nitrate can allow for additional growth of algae. Subsequently, this will result in an increase in decaying algae and a decrease in DO from oxygen utilization by decomposition processes (Carpenter et al. 1998). In eutrophic lakes, bacterial nitrification ceases and the adsorptive capacity of $\mathrm{NH}_{4}^{+}$in sediments is reduced due to anaerobic conditions (Wetzel 2001). This results in a release of $\mathrm{NH}_{4}{ }^{+}$from sediments and 
subsequent increase in $\mathrm{NH}_{4}{ }^{+}$in the overlying waters. Additionally, anaerobic conditions allow for some facultative anaerobic bacteria to utilize nitrite and nitrate as terminal electron acceptors to convert nitrate into $\mathrm{N}_{2}$ and $\mathrm{N}_{2} \mathrm{O}$, in a process known as denitrification (Austin 1988; Stumm and Morgan 1996; Wetzel, 2001).

\subsubsection{Heavy Metals}

Heavy metals commonly found in stormwater runoff include cooper, lead, zinc, arsenic, cadmium, and chromium (Makepeace et al. 1995; Mayer et al. 1996; Lee et al. 1997; Brown and Peake 2006). These metals are toxic to aquatic organisms and are persistent in the environment, as they cannot be chemically transformed or destroyed (Borchardt and Sperling 1997; Davis et al. 2001; Brown and Peake 2006; Søberg et al. 2016). Metals are often bound to particles in runoff when entering a stormwater pond (Davis et al. 2001; Karlsson et al. 2010) and are susceptible to being released into the dissolved phase in trace amounts, depending on the $\mathrm{pH}$ (Tai 1991) and dissolved organic carbon in the water column (Hamilton et al. 1984).

\subsubsection{Polycyclic Aromatic Hydrocarbons (PAHs)}

PAHs are compounds made up of two or more aromatic rings. They are formed during thermal decomposition of organic molecules (Haritash and Kaushik 2009). Common sources of PAHs in the environment include motor vehicle emissions, asphalt leaching, particles from tire abrasion, lubricating oils, and burning of fossil fuel, coal tar, wood, and garbage (Ngabe et al. 2000; Brown and Peake 2006; Haritash and Kaushik 2009). The greater molecular weight PAHs have (i.e. higher number of aromatic rings), the lower their solubilities in water and the slower their rates of biodegradation (Davis and McCuen 2005; Haritash and Kaushik 2009). Due to their low solubility in water, PAHs are commonly found adsorbed to sediment, 
accumulating in stormwater ponds (Durand et al. 2004; El-Mufleh et al. 2014). Their

persistence in the environment is of great concern as they can bioaccumulate in organisms and are also carcinogenic (Haritash and Kaushik 2009).

\subsubsection{Pesticides}

Pesticides, including insecticides, herbicides, and fungicides, have been detected in many urban streams (Daniels et al. 2000; Paul and Meyer 2001; Amweg et al. 2006; Weston et al. 2009). It has been estimated that $70-97 \%$ of homes in the United States use a total of more than $136,000 \mathrm{~kg}$ of pesticides (LeVeen and Willey 1983; USGS 1999). Pesticides in urban runoff are a major problem as pesticides applied before a rain event are easily washed away (Davis and McCuen 2005). For example, various studies have used the amphipod Hyalella azteca as a test organism for pesticide toxicity tests from urban runoff and have shown that residential runoff is a source of pyrethriod insecticides containing high enough concentrations to impact aquatic organisms (Amweg et al. 2006; Weston et al. 2009).

\subsection{Stormwater Pond Performance for Suspended Solids and Nutrient Removal}

Although many pollutants have been mentioned above, the scope of this study will focus on the suspended solids and nutrient removal ability stormwater ponds have. While stormwater ponds have been in place for decades (McCuen et al. 1983; Debo and Reese 1995), only a few studies in the literature (e.g. Mayer et al. 1996; Wu et al.1996; Borden et al. 1998; Comings et al. 2000; Mallin et al. 2002; Winston et al. 2013) have examined their performance for nutrient removal. The results from these studies have shown very little consistency amongst each other. For example, some studies have yielded a range of annual removal efficiencies, the percent difference of pollutant mass entering and leaving pond, of total phosphorus from $19 \%$ to $57 \%$ 
(Comings et al. 2000; Mallin et al. 2002; Winston et al. 2013). Winston et al. (2013) found that the annual removal efficiency of total nitrogen varied between the two ponds that were studied, with one pond having a removal efficiency of $36 \%$ and $59 \%$ in the other. Studies by Mayer et al. (1996) and Mallin et al. (2002) have even observed a net export of accumulated TP and TN from their stormwater retention ponds. The removal of total suspended solids by stormwater ponds have also showed a range of results in previous studies (Wu et al. 1996; Winston et al. 2013) with one study showing $41 \%$ removal efficiency and $92 \%$ removal efficiency in another. Despite the variation found in stormwater ponds reported by past research, most studies showed that stormwater ponds were able to provide some level of nutrients and suspended solids removal.

The inconsistencies shown in past research may be a result of various factors, including: retention time, the physical characteristics of the ponds, catchment type, the biota within the ponds, and weather conditions. The retention time of ponds is an important factor as a higher retention time may allow for physical, chemical, and biological processes to provide treatment of the water entering the ponds, through sedimentation and biological uptake, and may allow for a lower mass of pollutants entering the receiving body of water (Davis and McCuen 2005). Pond shape and depth can also influence the performance of stormwater ponds to retain pollutants. Ponds with higher length-to-width ratios and storage capacities allow for long retention times and thus, better retention (Sønderup et al. 2015). For example, when comparing pond depths between the studies by Mayer et al. (1996) and Wu et al. (1996), the Tapscott Pond in Mayer's study had an average depth of $0.8 \mathrm{~m}$ and Lakeside Pond in Wu's study had an average depth of $2.4 \mathrm{~m}$. In terms of performance, Tapscott Pond was found to be a net exporter of phosphorus and nitrogen, whereas Lakeside Pond retained both phosphorus and nitrogen. 
However, it is important to look at the catchment types as well when comparing ponds from different studies. Sønderup et al. (2015) showed that urban, rural, and developing catchments had lower pollutant concentrations compared to industrial and mixed catchment areas. When revisiting the example above, Tapscott Pond mainly drains an agricultural area and Lakeside Pond is located within a residential area. The difference in catchment area type may explain why Tapscott Pond performed poorly, but if designed properly to suit its conditions, one would expect it could perform well. As stormwater ponds are designed to retain runoff, rainfall and inflow of TSS, phosphorus, and nitrogen are positively related (Mallin et al. 2002; Sønderup et al. 2015).

Although studies in the past have looked at individual factors which may affect a pond's performance, as described above, none have examined the actual mechanisms that drive retention within the pond. It is proposed that stormwater ponds function to remove pollutants mainly by sedimentation and biological uptake. Many have studied whether there was retention of nutrients and TSS in the water column by examining the difference between inlet and outlet concentrations. However, no study in the literature has analyzed the process of sedimentation in removing nutrients from the water column in stormwater ponds.

\subsection{Objectives of Study}

The objectives of this study are to: 1) evaluate and compare the nutrient removal efficiency of two similar stormwater ponds, simultaneously, in the City of Toronto 2) examine the mechanisms by which stormwater ponds remove nutrient pollutants, including the importance of deposition and internal loading to help improve the understanding of why some ponds function well and others more poorly. 


\title{
2. Evaluation of Nutrient Retention and Sediment Deposition in Two Urban Stormwater Retention Ponds
}

\author{
R. C. I. Cheung ${ }^{1}$, A. Hanief ${ }^{1}$, R. Lilwah ${ }^{1}$, V. Bostan ${ }^{2}$, A. Laursen ${ }^{2}$ \\ ${ }^{1}$ Environmental Applied Science and Management Program, Ryerson University, 350 Victoria \\ Street, Toronto, ON M5B 2K3 \\ ${ }^{2}$ Department of Chemistry and Biology, Ryerson University, 350 Victoria Street, Toronto, ON \\ M5B2K3
}

\subsection{Introduction}

Municipalities in the 1970s began to recognize the need for localized management of stormwater to mitigate the effects of urbanization and increased impervious surfaces, and began integrating retention and detention ponds into stormwater management infrastructure (Debo and Reese 1995). Initially, these detention and retention basins were viewed to be more economical and more efficient than traditional stormwater conveyance systems at managing stormwater quantity (McCuen et al. 1983; Debo and Reese 1995), reducing and delaying peak flows by releasing runoff at rates close to predevelopment peak flow (Marsalek et al. 1992). Increased stormwater runoff associated with urbanization can lead to flooding, erosion, and deterioration to water quality in receiving bodies of water (Leopold 1968; Mattraw et al. 1978; Wanielista et al. 1982). Municipalities soon recognized that retention and detention ponds might, in addition to reducing peak flow volumes, also retain pollutants in stormwater runoff when designed properly. Further, they could also provide a community with improved aesthetics and recreational amenities (McCuen et al. 1983; Ferguson 1991). With climate change, particularly an increased frequency and intensity of storm events in some regions, storm water ponds may have growing importance in mitigating localized flooding in urban 
areas (Trenberth 2011), as well as in protecting surface water quality. However, the value of ponds in providing this latter ecosystem service is difficult to assess, as there are relatively few data on the ability of ponds to retain nutrient and other pollutants. The effective use of these ponds in reducing the impact of urban runoff on water quality, both under current and future climate scenarios, depends on better understanding of their function and capacity for nutrient retention. In this study, we consider the function of retention ponds, those containing permanent pools of water, as opposed to detention ponds which are dry except for a period of time after a storm (Ferguson 1991; Stanley 1996).

Sources of pollution in stormwater runoff can result from wet and dry atmospheric deposition, litter and dirt from streets, vegetation and organic residues, overflow from sanitary sewers, lawn and agricultural fertilizers, animal droppings, and materials from other activities (Novotny et al. 1985; Whipple et al. 1987; Makepeace et al. 1995). Some of the major pollutants in stormwater runoff include suspended solids, nutrients, heavy metals, polycyclic aromatic hydrocarbons (PAHs), and pesticides (USEPA 1983; Makepeace et al. 1995; Mayer et al. 1996; Characklis and Wiesner 1997; Lee et al. 1997; Waschbusch et al. 1999; Davis et al. 2001; Durand et al. 2004; Weston et al. 2009). Nutrients and suspended solids are a particular concern as they are major contributors to eutrophication (Carpenter et al. 1998). Phosphorus is generally the limiting nutrient in many freshwater systems and are the primary cause of eutrophication (Edmondson 1970; Maloney et al. 1972; Schindler 1974; Boyce et al. 1987). Urbanization has allowed nutrient compounds to enter receiving water bodies through runoff, creating eutrophic conditions. Suspended solids are composed of fine particulate matter of clay, silt, vegetation, and bacteria (Davis and McCuen 2005) which are picked up during runoff flow and held in the water column of a water body by turbulence (Bilotta and Brazier 2008). 
Suspended solids containing high organic matter may deplete dissolved oxygen concentrations within the water column during in situ decomposition (Wetzel 2001; Bilotta and Brazier 2008). To mitigate these negative effects, stormwater ponds have been built in urban areas to retain pollutants in runoff. This retention occurs by the adsorption of the pollutant to particulate matter, settling to the bottom of the pond, or by biological uptake of the pollutant, particularly nutrient pollutants (Wu et al.1996; Comings et al. 2000; Mallin et al. 2002; Winston et al. 2013). Pollutants that are taken up by algae, bacteria, and aquatic plants may also be deposited in sediments when the organisms senesce. If these materials become buried, retention of nutrients and other pollutants may be long-term, rather than merely seasonal. Mineralization of some organic nitrogen deposited by either mechanism may lead to coupled nitrification and denitrification, representing a more permanent removal of nitrogen by the retention ponds.

One of the major factors which affects the performance of stormwater ponds is the age of the pond (OMOE 2003; Drake and Guo 2008; Sønderup et al. 2015). As stormwater ponds are designed to retain solids from runoff, it is expected that sediment accumulation at the bottom of the pond will increase over time. However, this will result in a decrease in storage volume (Yousef et al. 1994; Graham and Lei 2000) and can greatly compromise the ability of stormwater ponds to perform their pollutant removal functions (Weiss et al. 2007; Egemose et al. 2015; Sønderup et al. 2015). Thus, it is important that stormwater ponds are properly maintained and sediment is periodically removed to ensure that they perform their function effectively. Various jurisdictions manage sediment removal and disposal from retention ponds as a part of infrastructure maintenance. For example, Ontario regulates sediment removal and disposal under the Water Resources Act and Environmental Protection Act (Graham and Lei 2000). The Stormwater Management Planning and Design Manual published by the Ontario 
Ministry of Environment (2003) provides recommendations for frequency of dredging as a function of pond type (e.g. retention vs. detention), storage volume, and percent impervious.

Although stormwater ponds have been widely used since the 1980 s, there have been relatively few studies in the primary literature on the performance of stormwater ponds in terms of their ability to retain nutrient pollutants (e.g. Wu et al.1996; Borden et al. 1998; Comings et al. 2000; Mallin et al. 2002; Winston et al. 2013). This ability likely depends on age of the pond and its maintenance, as nutrient retention is connected with deposition of particles. Of the studies present in the literature, many suggest limited value of stormwater ponds for nutrient retention. For example, several studies have shown annual average removal efficiencies of TP below 50\% (Wu et al.1996; Borden et al. 1998; Comings et al. 2000; Winston et al. 2013), and two studies, by Mayer et al. (1996) and Mallin et al. (2002), observed a net export of accumulated TP and TN over the entire season from the stormwater retention ponds.

The purpose of this study was to evaluate the function and ecosystem services provided by two wet retention ponds in an urban area, constructing a near-annual budget of nutrient inputs, outputs, and sedimentation. The results from this study will allow for the comparison and addition to the relatively few data available on stormwater retention ponds to advance the understanding of how these systems function in nutrient and sediment removal, and how environmental conditions and design/application may affect their performance in delivering these services. 


\subsection{Materials and Methods}

\subsubsection{Site Descriptions}

Hydro East Pond (HEP) and Mattamy Rouge (MAT) are stormwater ponds located in Scarborough, ON, designed for control of stormwater quantity and quality discharging into the Rouge River (Fig. 2.1). Located within residential areas, HEP was built in 2001 and MAT in 2004 (Table 2.1). HEP serves a catchment area of 63.7 ha and has a storage capacity of 5958 $\mathrm{m}^{3}$ and a permanent storage volume of $2392 \mathrm{~m}^{3}$. MAT serves a smaller catchment basin of 48.4 ha and has a larger storage capacity of $26000 \mathrm{~m}^{3}$, with a permanent storage volume of $8000 \mathrm{~m}^{3}$.
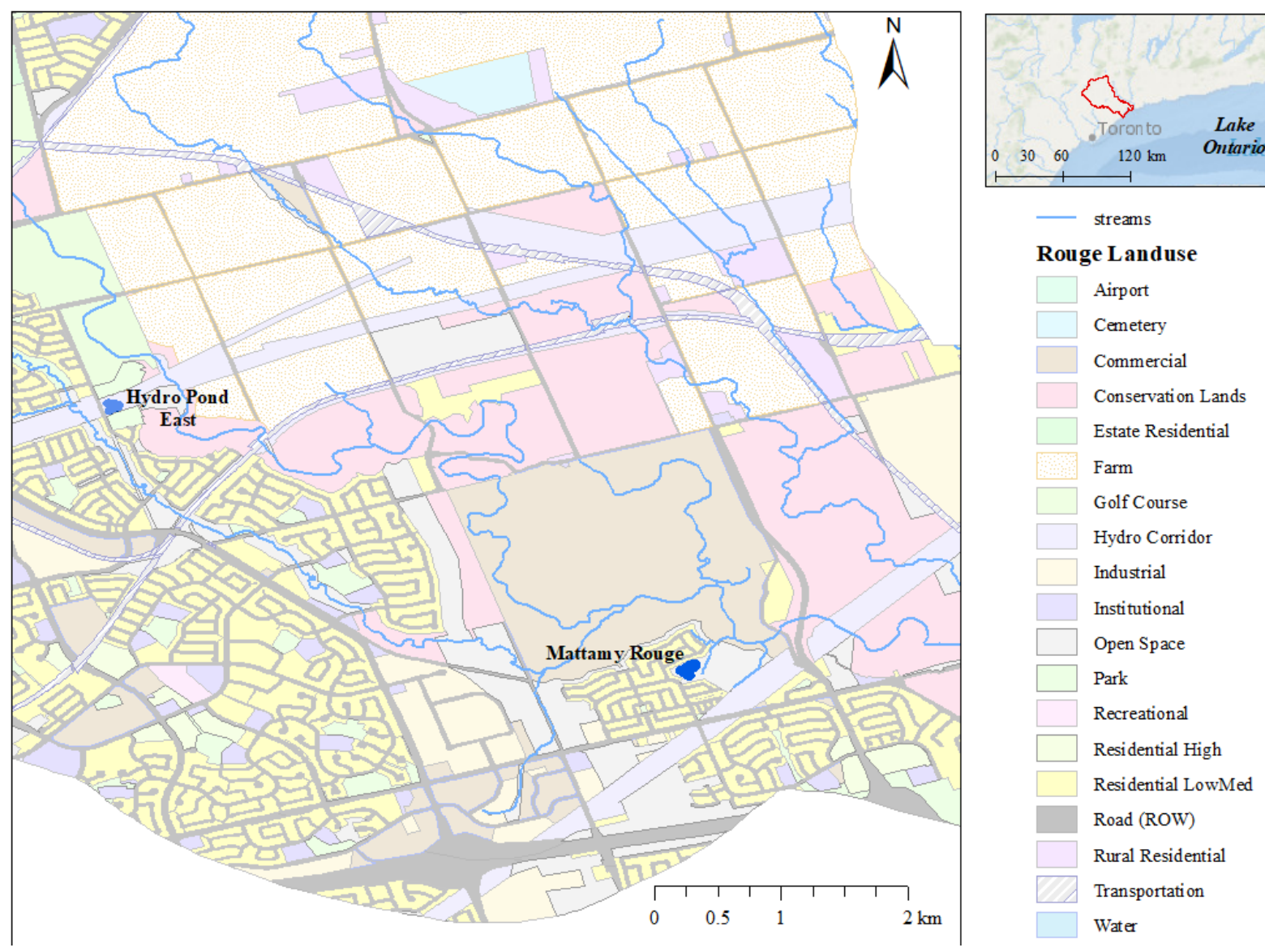

- streams

Rouge Landuse

Airport

Cemetery

Commercial

Conservation Lands

Estate Residential

Farm

Golf Course

Hydro Corridor

Industrial

Institutional

Open Space

Park

Recreational

Residential High

Residential LowMed

Road (ROW)

Rural Residential

Transportation

Water

Fig. 2.1 Map displaying the locations and proximity of Hydro East Pond and Mattamy Rouge Pond in Toronto, Ontario, Canada. (ESRI base map, TRCA land use shapefile) 
Table 2.1 Characteristics of Hydro East and Mattamy Rouge stormwater ponds.

\begin{tabular}{|l|l|l|}
\hline Characteristics & Hydro East Pond & Mattamy Rouge Pond \\
\hline Built (year) & 2001 & 2004 \\
\hline Purpose & Quantity and quality & Quantity and quality \\
\hline Land use & Residential & Residential \\
\hline Catchment area (ha) & 63.7 & 48.4 \\
\hline Storage capacity $\left(\mathrm{m}^{3}\right)$ & 5958 & 26000 \\
\hline Permanent storage $\left(\mathrm{m}^{3}\right)$ & 2392 & 8000 \\
\hline Permanent water level $(\mathrm{cm})$ & 160.25 & 110.44 \\
\hline Surface area $\left(\mathrm{m}^{2}\right)$ & 5443.75 & 9644.75 \\
\hline
\end{tabular}

\subsubsection{Field Sampling Methods}

\subsubsection{Water and Sediment Sampling}

Water samples $(>500 \mathrm{~mL})$ were collected as grab samples at $\sim 30 \mathrm{~cm}$ depth, near the inlet and outlet of each pond (Fig. 2.2) to permit determination of retention within each pond.

Samples were collected at approximately 2-3 week intervals between April and June 2016, and longer intervals (4-6 weeks) later in the season (Table 2.2).

Table 2.2 Field monitoring and sampling schedule at Hydro East and Mattamy Rouge ponds.

\begin{tabular}{|l|c|c|c|c|c|c|c|c|c|c|c|c|c|c|}
\hline & $\begin{array}{c}\text { Apr. } \\
8\end{array}$ & $\begin{array}{c}\text { Apr. } \\
20\end{array}$ & $\begin{array}{c}\text { May } \\
5\end{array}$ & $\begin{array}{c}\text { May } \\
12\end{array}$ & $\begin{array}{c}\text { May } \\
31\end{array}$ & $\begin{array}{c}\text { Jun. } \\
1\end{array}$ & $\begin{array}{c}\text { Jun. } \\
7\end{array}$ & $\begin{array}{c}\text { Jun. } \\
15\end{array}$ & $\begin{array}{c}\text { Jul. } \\
8\end{array}$ & $\begin{array}{c}\text { Jul. } \\
27\end{array}$ & $\begin{array}{c}\text { Aug. } \\
19\end{array}$ & $\begin{array}{c}\text { Sept. } \\
16\end{array}$ & $\begin{array}{c}\text { Nov. } \\
5\end{array}$ & $\begin{array}{c}\text { Dec. } \\
12\end{array}$ \\
\hline $\begin{array}{l}\text { Nutrients } \\
\text { (w \& s })\end{array}$ & $\mathrm{X}$ & $\mathrm{X}$ & $\mathrm{X}$ & $\mathrm{X}$ & $\mathrm{X}$ & $\mathrm{X}$ & $\mathrm{X}$ & $\mathrm{X}$ & $\mathrm{X}$ & $\mathrm{X}$ & $\mathrm{X}$ & $\mathrm{X}$ & $\mathrm{X}$ & $\mathrm{X}$ \\
\hline $\begin{array}{l}\text { Sediment } \\
\text { Traps }\end{array}$ & & & & & & & & & $\mathrm{X}$ & $\mathrm{X}$ & $\mathrm{X}$ & $\mathrm{X}$ & $\mathrm{X}$ & \\
\hline
\end{tabular}

A composite sample (1 L) was also collected, which consisted of a mixture of water of equal volumes collected from the inlet, outlet, and three additional points (Fig. 2.2, points A, B, and C) of the pond. Water samples were collected for the analysis of total phosphorus (TP), dissolved reactive phosphorus (DRP), ammonium $\left(\mathrm{NH}_{4}{ }^{+}\right)$, and nitrate $\left(\mathrm{NO}_{3}{ }^{-}\right)$. Water clarity was measured using a Secchi disk at three locations (Fig. 2.2 - A, B, and C) within each pond, on each date. 

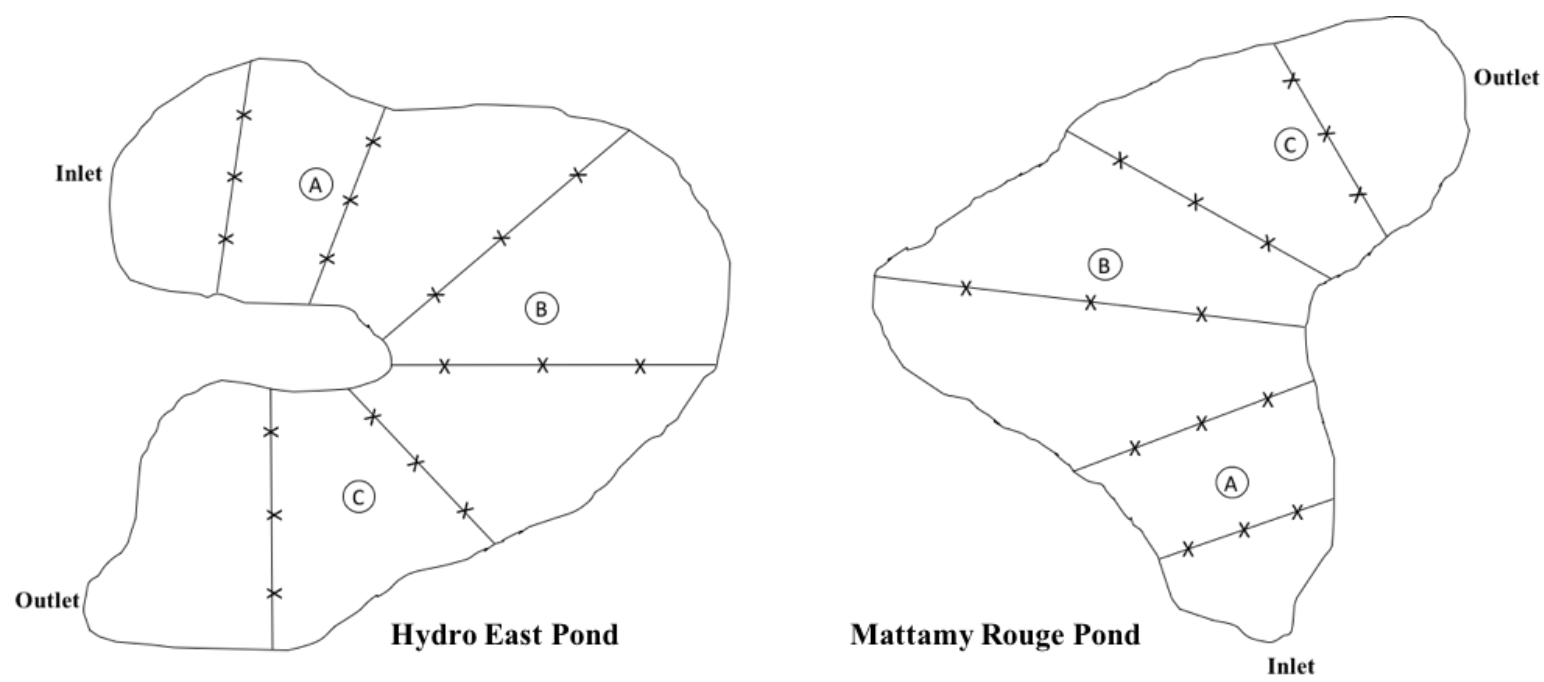

Fig. 2.2 Map of the sampling points at Hydro East Pond and Mattamy Rouge Pond.

A clear acrylic tube $(3 \mathrm{~cm} \times 2.16 \mathrm{~m})$ fitted with a valve on the top was used to collect bottom sediment samples near the middle of the pond. The coring tube was lowered gently into the sediment with the valve open. The valve was then closed to maintain suction. The coring tube was removed and the valve slowly opened to evacuate all but the top $10 \mathrm{~cm}$ of sediment. This top fraction of the sediment core was collected and composited with two other such samples from each pond on each date. Sediment cores were collected to measure pore water and particulate concentrations of TP and TN.

\subsubsection{Measurement of Sedimentation Rate}

Sediment traps were used to study deposition of particulate matter. Following the recommendations of Bloesch and Burns (1980), sediment traps were constructed with funnels (30-cm diameter) and 50-mL test tubes attached to the bottom to collect sediment that was being deposited. A mesh screen (nylon, $1 \mathrm{~cm} \mathrm{x} 1 \mathrm{~cm}$ ) was attached to cover the openings of the funnels to exclude large debris. Three sediment traps were installed at points A, B, and C (Fig. 2.2) in each pond during mid to late summer (Table 2.2). 


\subsubsection{Measurement of Temperature and Dissolved Oxygen}

Temperature and dissolved oxygen (DO) concentrations were measured at points A, B, and $\mathrm{C}$ in each pond using a handheld field meter (HI 9828, Hanna Instruments, Woonsocket, $\mathrm{RI})$. Temperature and DO profiles were created by taking measurements in $10 \mathrm{~cm}$ depth intervals from the pond surface to the pond bottom.

\subsubsection{Meteorological Data}

Local precipitation and daily mean temperature data were obtained from a weather station located at University of Toronto, Scarborough.

\subsubsection{Laboratory Methods}

\subsubsection{Sample Processing and Storage}

Water samples were filtered through pre-ashed $\left(550^{\circ} \mathrm{C}\right.$ for 4 hours $)$ and pre-weighed Whatman GF/F filters $(0.7 \mu \mathrm{m})$ and subsequently filtered through a $0.22-\mu \mathrm{m}$ pore size filter (PolyPropylene Membrane Filter, Membrane Solutions). Unfiltered water samples were used to determine total phosphorus concentrations. Filtered water samples were used for the determination of dissolved reactive phosphorus, ammonium, nitrate, and total nitrogen concentrations. Filters from the inlet and outlet water samples were dried $\left(105^{\circ} \mathrm{C}\right.$ for 12 hours $)$,

reweighed, and used to calculate total suspended solids (TSS; $\left.\mathrm{mg} \mathrm{L}^{-1}\right)$. Sediment samples (50 g) were centrifuged at $5000 \mathrm{rpm}$ for 15 minutes and the supernatant was decanted to obtain a pore water sample. Processed water, pore water, and sediment samples were frozen at $-20^{\circ} \mathrm{C}$ until analysis. 


\subsubsection{Organic Matter in Sediment Samples}

Organic matter in sediment samples was determined by the ignition method (Howard and Howard 1990). A sample ( 0.5 g) of dried sediment $\left(105^{\circ} \mathrm{C}\right.$ for 12 hours $)$ was sieved ( $2 \mathrm{~mm}$ mesh), and weighed into ceramic crucibles (pre-weighed, pre-ashed). The samples were then placed into a muffle furnace and were ignited at $550^{\circ} \mathrm{C}$ for 2 hours, cooled in a drying oven $\left(105^{\circ} \mathrm{C}\right)$, and re-weighed. Percent organic matter was determined by difference between the preignited and post-ignited mass.

\subsubsection{Analysis of Nutrient Composition in Water and Sediment Samples}

The nutrient concentrations in water samples were analyzed using colorimetric methods (American Public Health Association 2012), based upon modifications of the cadmium reduction technique for nitrate (Wood et al. 1967), the ascorbic acid method for phosphate (Murphy and Riley 1962), and the phenate method for ammonium (Solórzano 1969). Total phosphorus and inorganic phosphorus in sediment were extracted using $1 \mathrm{M}$ hydrochloric acid (Aspila et al. 1976). Organic phosphorus concentrations in sediment were determined from the difference between phosphorus extracted with $50 \mathrm{~mL}$ of $1 \mathrm{M}$ hydrochloric acid in $0.5 \mathrm{~g}$ of dried, unignited (inorganic phosphorus fraction) and ignited (total phosphorus fraction, $550^{\circ} \mathrm{C}$ for 2 hours) sediment samples. Extractions were done at room temperature for $16 \mathrm{~h}$, in centrifuge tubes, agitated using a bench top shaker. After extraction, aliquots of each sample were transferred into $15-\mathrm{mL}$ centrifuge tubes and centrifuged at $5500 \mathrm{rpm}$ for 15 minutes. The supernatant of each sample was used to determine total and inorganic phosphorus concentrations by the ascorbic acid method. 


\subsubsection{Nutrient Retention}

Nutrient removal/retention efficiency can be defined as the amount of a pollutant retained to the amount of pollutant which entered the pond (Davis and McCuen 2005). As it is difficult to measure the amount of pollutant retained, the amount of pollutant in the outflow can be used through mass balance principles, where the percent removal/retention efficiency (RE) can be mathematically defined as:

$$
R E=\left(1-\frac{C_{\text {out }}}{C_{\text {in }}}\right) \times 100
$$

where, $\mathrm{C}_{\text {out }}$ is the pollutant concentration found in the outflow and $\mathrm{C}_{\text {in }}$ is the amount of pollutant in the inflow (Davis and McCuen 2005). A positive value indicates the percentage of pollutant which has been retained within the stormwater pond and a negative value represents the percentage of excess pollutant which has been discharged (Davis and McCuen 2005).

\subsubsection{Estimation of Flow and Nutrient Loading}

The loading of phosphorus and nitrogen into ponds was calculated based on the concentrations of nutrients at the inlet to each pond $\left(\mathrm{mmol} \mathrm{m}^{-3}\right)$, and an estimate of water volume entering the pond $\left(\mathrm{m}^{3} \mathrm{~d}^{-1}\right)$. Water volume at the inlet was calculated using the Rational Method for estimation of storm water flow (Toronto Water, 2009), assuming that all run-off within a stormwater pond's catchment entered the pond during the interval between sample collections. Flow was estimated as:

$$
\mathrm{Q}=2.78 \times \mathrm{A} \times \mathrm{C} \times \mathrm{I}
$$

where $\mathrm{Q}$ is flow $\left(\mathrm{L} \mathrm{s}^{-1}\right)$, A is area of drainage (ha), C is a run-off coefficient for land use, and I is intensity of rainfall $\left(\mathrm{mm} \mathrm{h}^{-1}\right)$. For single-family homes, the predominant land-use type within each storm water pond's catchment, the City of Toronto uses a runoff coefficient of 0.65 , which 
was applied here. Total rainfall was summed over a period of 15 days prior to each sampling date, and divided by 360 hours to estimate hourly precipitation over that interval. The volume of water leaving the pond was assumed equal to the volume entering the pond on each sampling date, and was multiplied by nutrient concentrations at the outflow to estimate export of nitrogen and phosphorus.

\subsubsection{Estimation of Pond Surface Area, Volume, and Hydraulic Retention Time}

The ruler tool in Google Earth Pro was used to measure the surface area of MAT and HEP ponds as polygons. The surface area was multiplied by depth on each date to calculate volume. For each date, minimum, maximum, and quartile depths were determined from among the sampling points (18 in HEP and 15 in MAT). Volume was calculated assuming $5 \%$ of the pond's surface was represented by the minimum depth value, $5 \%$ by the maximum depth value, and $30 \%$ by each of the quartile values. Volume and water inflow were used to calculate hydraulic retention time, and net daily average retention for each sampling interval.

\subsubsection{Statistical Analyses}

Water quality data were statistically analyzed to compare the difference between the two ponds based on composite concentrations, treating rainfall and temperature as continuous variables in ANCOVA models. Statistical analyses were performed on SAS 94.

\subsection{Results and Discussion}

\subsubsection{Temperature and DO Concentrations}

Temperature and DO concentration profile measurements were conducted at both HEP and MAT over the entire sampling season. Stratification was first observed in both ponds on June 15, 2016 (Fig. 2.3) and persisted throughout the summer season until late autumn. 


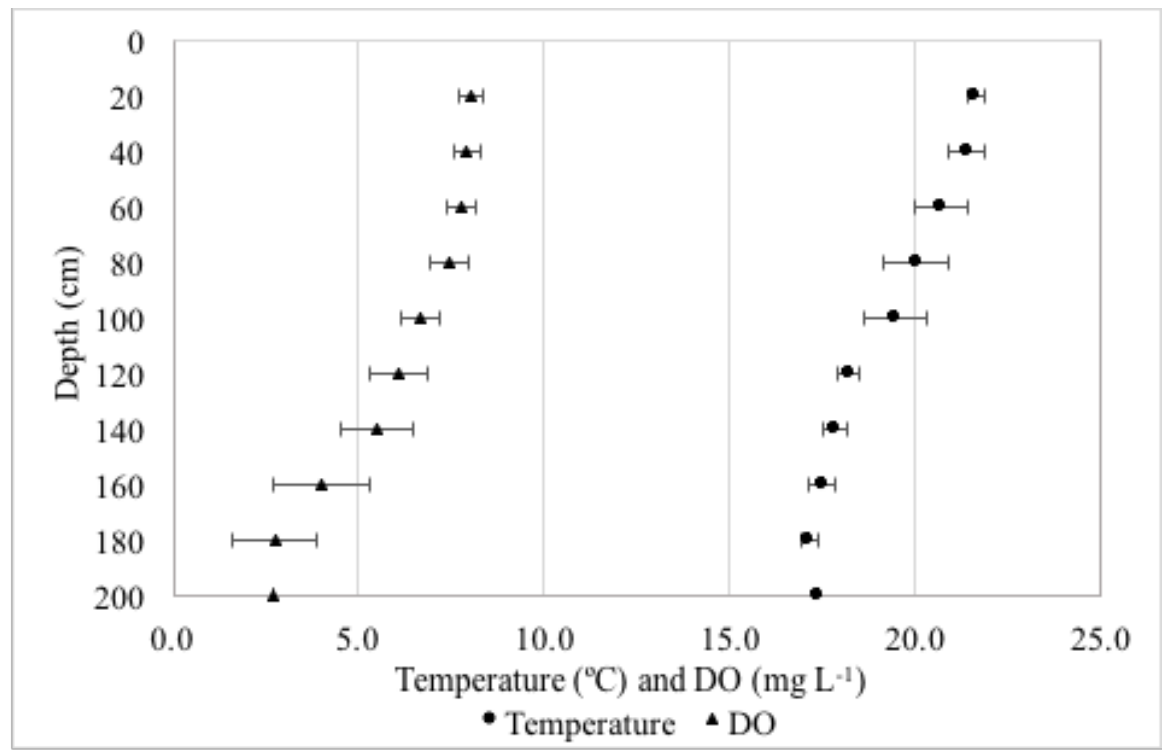

a)

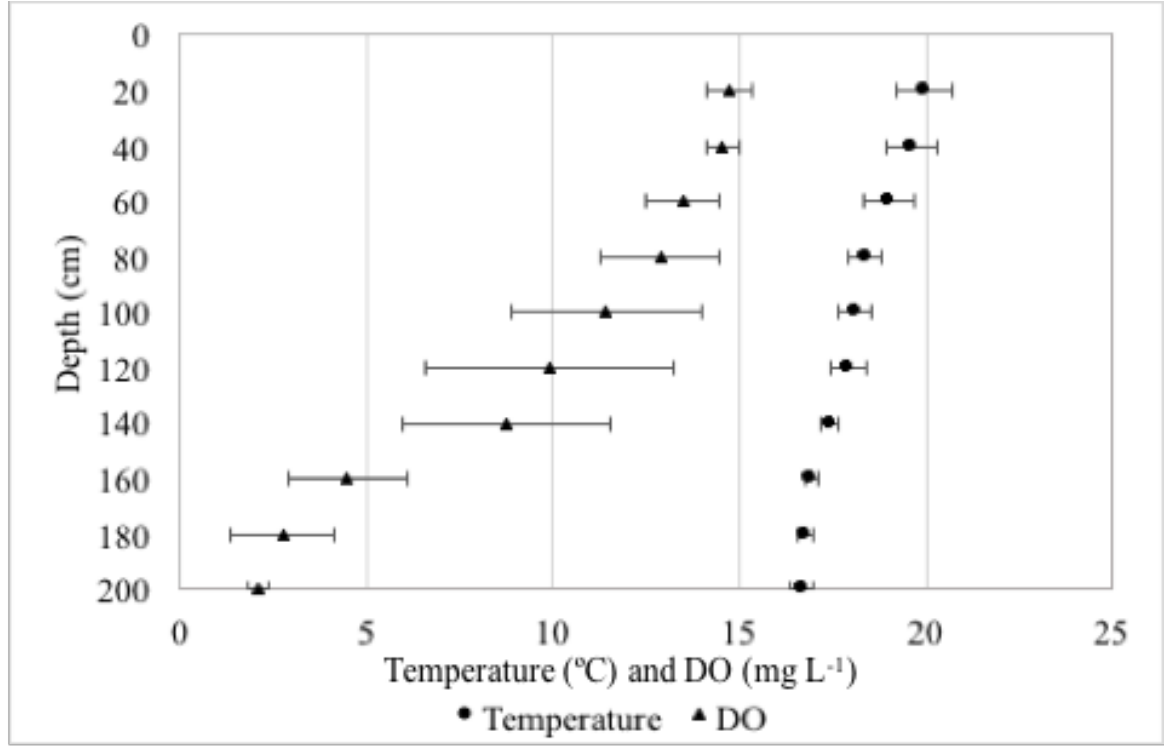

b)

Fig. 2.3 Temperature and Dissolved Oxygen (DO) concentrations measured at depths of $10 \mathrm{~cm}$ intervals from the pond surface to the pond bottom on June 15, 2016. a) HEP b) MAT. 


\subsubsection{Nutrient Concentrations}

A total of twelve sampling days occurred between April and December of 2016 (Table 2.2). The average concentrations of $\mathrm{DRP}, \mathrm{TP}$, and $\mathrm{NH}_{4}{ }^{+}$over the entire sampling period were similar between HEP and MAT. However, average concentrations of $\mathrm{NO}_{3}{ }^{-}$in HEP were significantly different between ponds, controlling for temperature and rainfall as covariates (ANCOVA, $\mathrm{p}=0.0105 ; \mathrm{p}=0.6400$, respectively). HEP is located directly beside a residential roadway which may explain why concentrations of $\mathrm{NO}_{3}{ }^{-}$are higher than in MAT. A previous study by Kojima et al. (2011) found that road dust accounted for more than half of the nitrate found in surface runoff. With the exception of nitrate, nutrient constituents measured were comparable with previous studies on stormwater retention ponds (Table 2.3). The 2016 season in Toronto was generally dry and the low frequency of flushing may have played a role in the higher nitrate concentrations. The values obtained from the study by Mayer et al. (1996) are of particular interest, as the study was also done within the Greater Toronto Area. Nitrate values reported by Mayer et al. (1996) were also higher than those reported in studies elsewhere, however they were much lower than in the current study. Further investigation should be done to determine the sources and concentrations of $\mathrm{NO}_{3}{ }^{-}$in stormwater runoff within the Greater Toronto Area. 
Table 2.3 Summary of data comparison between study and previous studies on stormwater ponds. Values in parenthesis are concentration ranges observed.

\begin{tabular}{|c|c|c|c|c|c|}
\hline \multirow[b]{2}{*}{ Study } & \multirow[b]{2}{*}{ Ponds } & \multicolumn{4}{|c|}{ Mean Concentrations Over the Sampling Season $(\mu \mathrm{M})$} \\
\hline & & DRP & $\mathrm{TP}$ & $\mathrm{NH}_{4}^{+}$ & $\mathrm{NO}_{3}$ \\
\hline \multirow{2}{*}{ Current Study } & HEP & $1.18(0.38-2.43)$ & $3.58(0.51-7.49)$ & $6.65(0.80-16.72)$ & $99.9(33.31-251.09)$ \\
\hline & MAT & $1.44(0.22-4.08)$ & $4.10(1.07-9.88)$ & $3.70(1.19-11.87)$ & $40.6(10.27-197.50)$ \\
\hline \multirow{4}{*}{ Mayer et al. (1996) ${ }^{[1]}$} & Heritage & 2.86 & 5.34 & 13.15 & 16.43 \\
\hline & S. Smith & 1.87 & 4.16 & 9.38 & 18.66 \\
\hline & Tapscott & 0.48 & 2.41 & 5.57 & 15.25 \\
\hline & Unionville & 0.98 & 3.11 & 13.03 & 7.51 \\
\hline \multirow{3}{*}{ Wu et al. $(1996)^{[2]}$} & LS Pond & - & 4.84 & - & - \\
\hline & WF Pond & - & 4.84 & - & - \\
\hline & RB pond & - & 5.81 & - & - \\
\hline \multirow{2}{*}{$\begin{array}{l}\text { Borden et al. } \\
(1998)^{[3]}\end{array}$} & Davis & 5.20 & 9.27 & 5.38 & 4.40 \\
\hline & Piedmont & 0.97 & 4.28 & - & 2.86 \\
\hline \multirow{2}{*}{$\begin{array}{l}\text { Comings et al. } \\
(2000)^{[4]}\end{array}$} & Pond $\mathrm{C}$ & 0.84 & 2.81 & - & - \\
\hline & Pond A & 0.48 & 2.49 & - & - \\
\hline \multirow{3}{*}{ Mallin et al. $(2002)^{[5]}$} & Ann & 0.87 & 1.74 & 3.66 & - \\
\hline & McCrary & & & & \\
\hline & $\begin{array}{l}\text { Silver } \\
\text { Stream }\end{array}$ & 1.99 & 3.25 & 6.79 & - \\
\hline \multirow{2}{*}{$\begin{array}{l}\text { Winston et al. } \\
(2012)^{[6]}\end{array}$} & DOT & 4.20 & 6.94 & - & 2.26 \\
\hline & Museum & 3.23 & 5.97 & - & 1.45 \\
\hline $\begin{array}{l}\text { Schwartz et al. } \\
\quad(2017)^{[7]}\end{array}$ & $\begin{array}{l}\text { Ashby } \\
\text { Pond }\end{array}$ & 1.29 & 6.13 & 4.16 & 4.35 \\
\hline
\end{tabular}

[1] Ponds were located in the Greater Toronto Area; Heritage and Unionville ponds drained residential areas; Smith pond drained from industrial and commercial lands, and a major highway; Tapscott pond received runoff from agricultural lands; samples collected during February -

November, 1993. [2] Stormwater ponds drained from residential areas; samples collected over a 13-month period (no year specified). [3] Davis pond drained from agricultural land; Piedmont pond drained from an industrial area; samples collected from December 1993 - November 1994. [4] Stormwater ponds drained from residential and commercial areas; samples collected from October 1996 - March 1997. [5] Stormwater ponds drained from residential areas, samples collected from October 1997 - February 2000. [6] DOT pond drained from a roadway; Museum pond drained from a parking lot, maintenance building, and picnic area; samples collected from December 2008 - February 2010. [7] Pond located in Northern Virginia; Stormwater pond drained from commercial and residential areas; samples collected from September 2012 - March 2013. 
When comparing each individual nutrient constituent between HEP and MAT, similar seasonal trends were observed between HEP and MAT (Fig. 2.4). Both ponds experienced a peak in DRP and TP concentrations during mid-summer, with declines over late summer into autumn (Fig. 2.4 a \& b). DRP concentrations were found to increase with increasing temperature and rainfall (ANCOVA, $p=0.0007 ; p=0.0023$, respectively). During the entire summer season, stratification was observed in the ponds and this likely caused a release of ironbound phosphate from the sediment due to the anoxic conditions at the sediment-water interface. Studies of shallow lakes have also shown maximum concentrations of phosphorus during mid-summer due to internal loading (Welch \& Cooke 1995; Ekholm et al. 1997; Jeppesen et al. 1997). It has also been demonstrated in previous studies that high phosphate export in runoff is associated with heavy rainfall events (Miguntanna et al. 2013; Hobbie et al. 2017). $\mathrm{NH}_{4}{ }^{+}$concentrations in HEP and MAT were highest during late spring and early summer when the ponds were mixed (Fig. 2.4c). This was likely due to the external loading from the spring flush of nutrients into the ponds. During early to mid-summer, concentrations of $\mathrm{NH}_{4}{ }^{+}$were low, likely due to a combination of biological uptake and nitrification. $\mathrm{NH}_{4}{ }^{+}$ increased again between mid to late summer and decreased at the start of autumn. This may have reflected internal loading from sediments during late summer. Stratification broke during early-autumn and oxic conditions were observed near the sediment and likely inhibited $\mathrm{NH}_{4}{ }^{+}$ release (Moore et al. 1992; Rysgaard et al. 1994; Beutel 2006) as sediment TN concentrations increased during the latter part of the year. As shown in Fig. 2.4d, the trends of $\mathrm{NO}_{3}{ }^{-}$ concentrations in HEP and MAT are similar over the sampling period, but as mentioned above, the concentrations within each pond were different when controlling for temperature and rainfall as covariates (Table 2.4). Both ponds experienced a spring flush of $\mathrm{NO}_{3}{ }^{-}$during early 
spring and concentrations were the highest during this season. This was likely due to precipitation and snowmelt in the spring season, as rain on snow events in southern Ontario have been found to export up to $24 \%$ of annual $\mathrm{NO}_{3}{ }^{-}$into streams (Crossman et al. 2016). $\mathrm{NO}_{3}{ }^{-}$ concentrations decreased rapidly after the peak in concentrations in spring and remained below $100 \mu \mathrm{M}$ during the summer season. This seasonal trend was similar to observations by Ledford et al. (2017) of a pulse of nitrate into an urban stream following a large rain event in the spring, and subsequently low nitrate concentrations in the summer due to autotrophic uptake. An increase in $\mathrm{NO}_{3}{ }^{-}$concentrations was observed during the early autumn season, with the increase greater in HEP than MAT. Nitrate was also found to have decreased with increased temperature (ANCOVA, $p=0.0105$ ). It is known that increased temperatures and anoxic conditions result in less flux of nitrate from the sediment due to higher denitrification rates, where nitrate and nitrite are reduced to $\mathrm{N}_{2} \mathrm{O}$ and $\mathrm{N}_{2}$ (Christensen and Sorensen 1986, Liikanen et al. 2002).

Table 2.4 Analysis of covariance results for nutrient concentrations, comparing ponds with temperature and rainfall as covariates.

\begin{tabular}{|l|c|c|}
\hline Constituent & $\mathrm{F}_{(1,20)}$ & $\mathrm{p}$ \\
\hline DRP & & \\
$\quad$ Pond & $1.24_{(1 / 0.458)}$ & 0.2787 \\
Temperature & $15.80_{(1 / 0.458)}$ & 0.0007 \\
Rainfall & $12.25_{(1 / 0.458)}$ & 0.0023 \\
$\mathrm{TP}$ & & \\
Pond & $0.20_{(1 / 6.601)}$ & 0.6563 \\
Temperature & $5.04_{(1 / 6.601)}$ & 0.0363 \\
Rainfall & $0.34_{(1 / 6.601)}$ & 0.5663 \\
& & \\
$\mathrm{NH}_{4}{ }^{+}$ & & \\
Pond & $2.45_{(1 / 17.919)}$ & 0.1334 \\
Temperature & $0.03_{(1 / 17.919)}$ & 0.8537 \\
Rainfall & $1.34_{(1 / 17.919)}$ & 0.2606 \\
& & \\
$\mathrm{NO}_{3}{ }^{-}$ & & \\
Pond & $6.67_{(1 / 3073.7)}$ & 0.0178 \\
Temperature & $7.97_{(1 / 3073.7)}$ & 0.0105 \\
Rainfall & $0.23_{(1 / 3073.7)}$ & 0.6400 \\
\hline
\end{tabular}



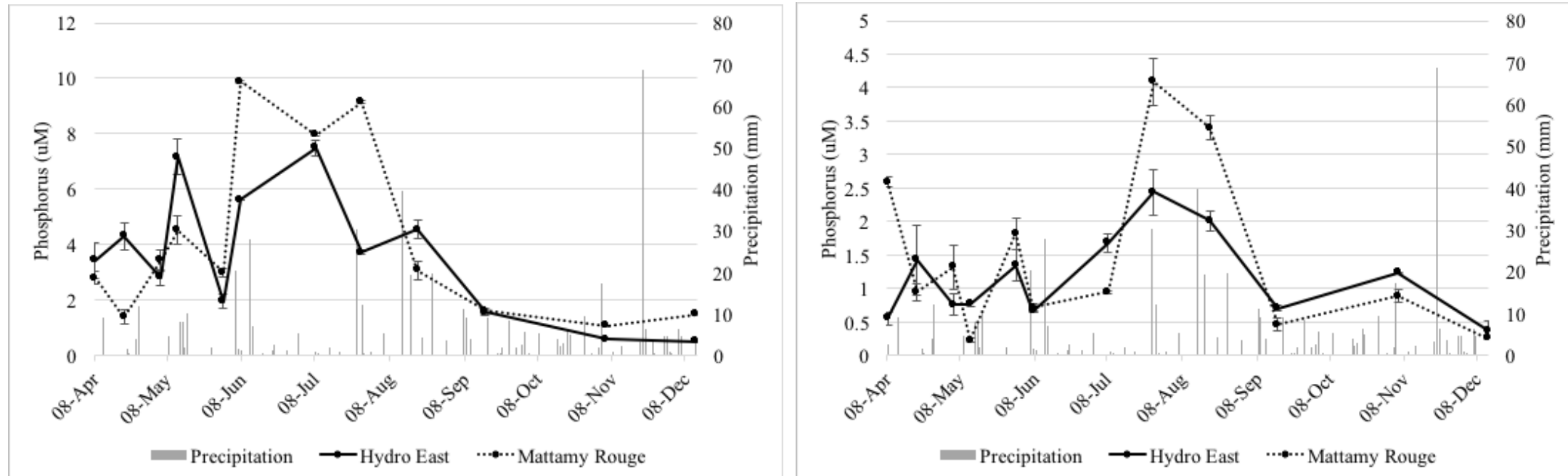

a)

b)
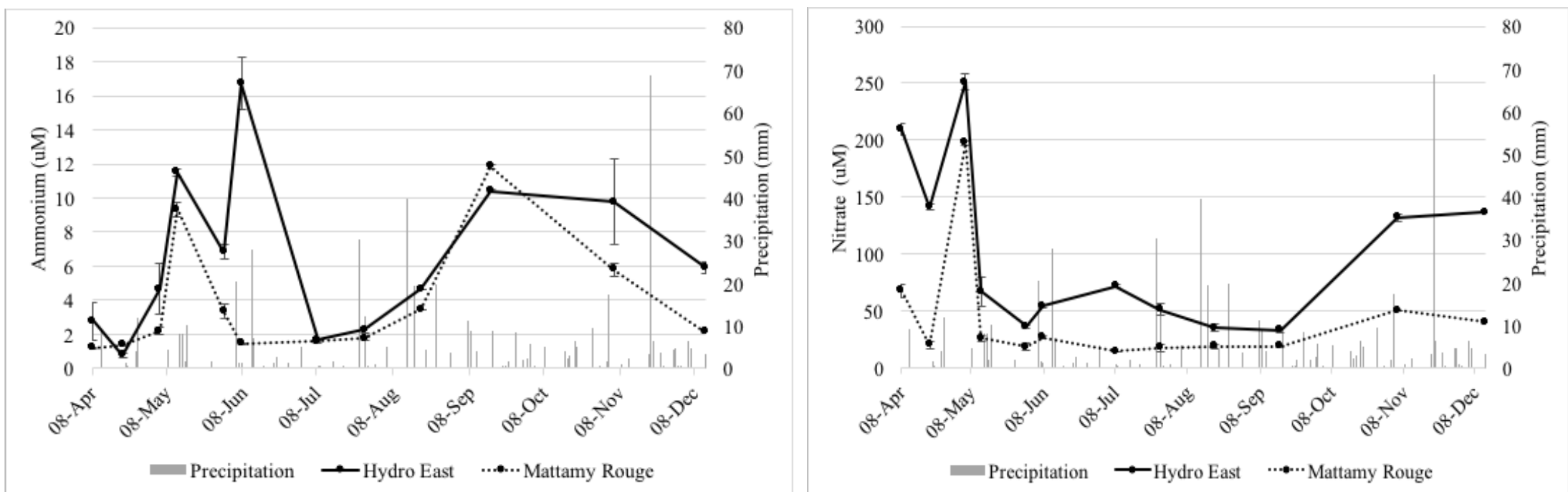

c)

d)

Fig. 2.4 Concentrations of nutrient constituents from composite samples in HEP and MAT and total precipitation during the two weeks prior to sampling date: a) total phosphorus, b) dissolved reactive phosphorus, c) ammonium, d) nitrate. 


\subsubsection{Percent Retention of Nutrients \& Total Suspended Solids}

One of the main purposes of stormwater ponds is to retain pollutants from runoff, mitigating export into receiving waters. Fig. 2.5 illustrates the percent retention of each nutrient constituent on individual sampling days over the entire sampling period. Both HEP and MAT experienced a high percent of TP export during late spring. Compared to previous studies on urban stormwater ponds, HEP and MAT performed poorly in regards to retention of TP as most other ponds studied were able to retain TP to some degree (Mayer et al. 1996; Wu et al. 1996; Borden et al. 1998; Comings et al. 2000; Mallin et al. 2002; Winston et al. 2013;

Schwartz et al. 2017). Percent retention of DRP was highest during mid-summer, suggesting that DRP may have been retained by biological uptake in the two ponds (Fig. 2.5b). Retention of DRP began to decline shortly after mid-summer and interestingly, rebounded in MAT but continued to decrease to negative values (net export) in HEP during the later summer to early winter. It is also notable that during the summer season, both ponds were exporting TP, but retaining DRP, suggesting biological uptake and export of $\mathrm{P}$ from the ponds as particulate matter (algae and bacteria). Both ponds experienced fluctuations in the retention/export of $\mathrm{NH}_{4}{ }^{+}$. Generally, retention of $\mathrm{NH}_{4}{ }^{+}$occurred during the summer months where it was likely controlled by biological uptake. $\mathrm{NO}_{3}{ }^{-}$was the only constituent which was retained in both ponds. The retention of $\mathrm{NO}_{3}{ }^{-}$was likely driven by the process of denitrification, where $\mathrm{NO}_{3}$ is lost as it becomes reduced to $\mathrm{N}_{2}$. High export of TSS was observed at the beginning of the study in both ponds, likely due to the flush of particulate matter from snowmelt. Retention of TSS occurred two weeks following the initial sampling date in early April and no export of TSS was observed in either ponds until mid-August. No retention or export was observed in HEP during September to November, whereas retention occurred in MAT during this time. 

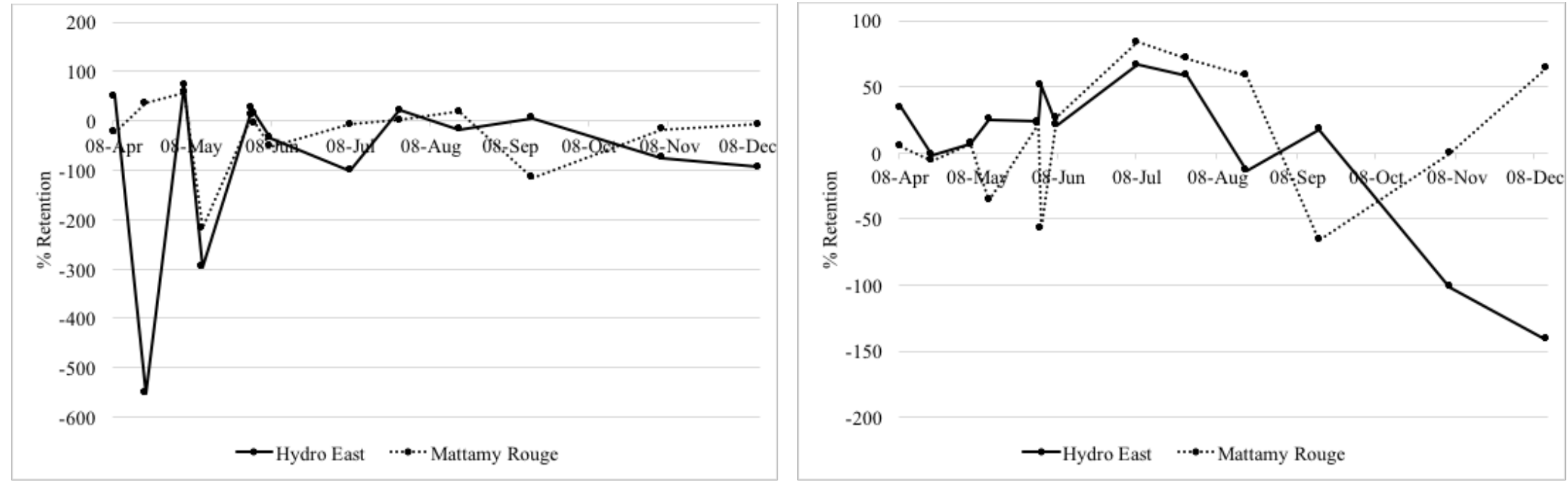

a)

b)

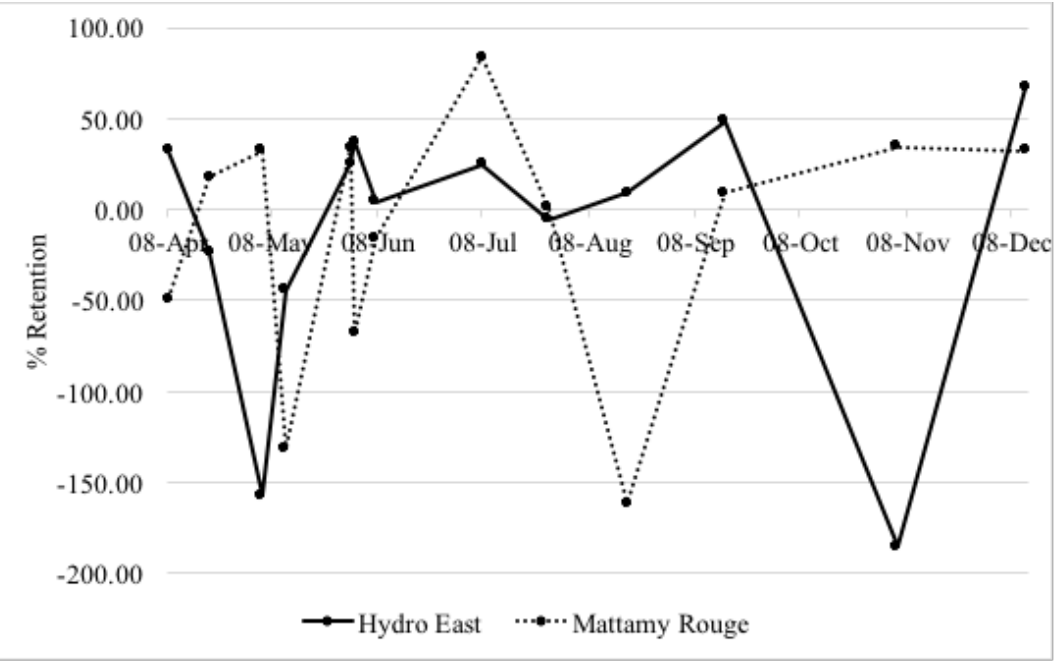

c)

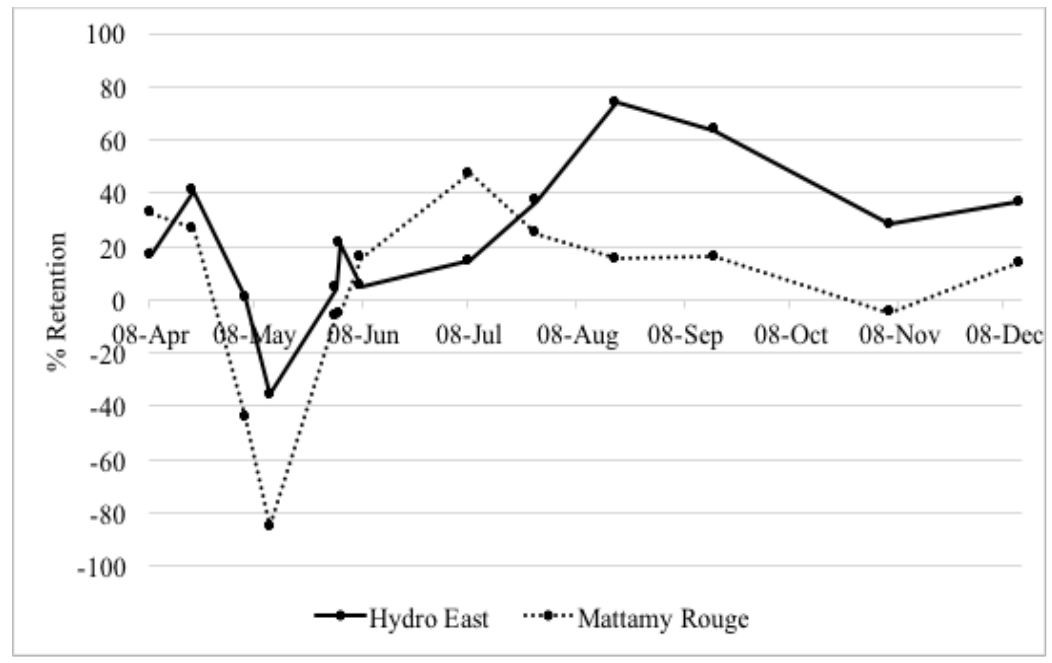

d) 


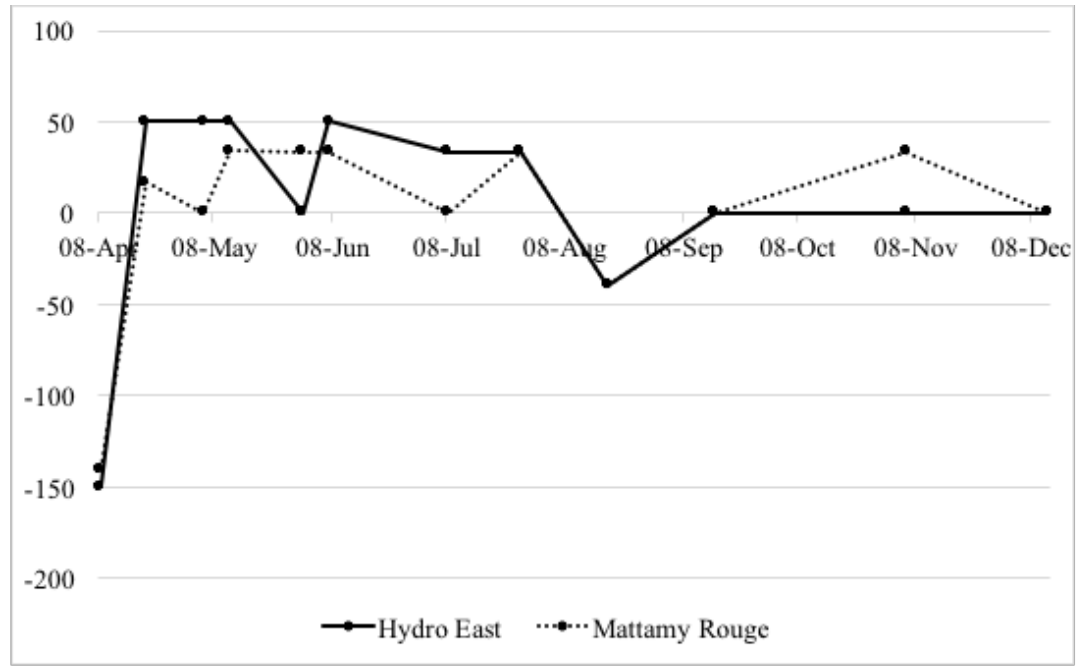

e)

Fig. 2.5 Percent retention of nutrient constituents and TSS in HEP and MAT: a) total phosphorus, b) dissolved reactive phosphorus, c) ammonium, d) nitrate, e) total suspended solids. 
The term 'retention' has been commonly expressed in literature as a percentage change over time. However, the original usage of 'retention' by Vollenweider (1975) was defined as the difference between what was imported into the lake and what was exported. For this study, we used the Vollenweider definition of retention, where the retention of different nutrient constituents over time was determined by weighting concentrations by the volume of water flowing into the pond on each sampling date.

HEP had a slightly larger catchment area, and smaller volume than MAT. Consequently, hydraulic retention time in MAT was, on average, slightly more than double in MAT (31.1 d) relative to HEP (13.9 d). Phosphorus and nitrogen loading were temporally variable, with highest loading during early April. Retention of nutrients also varied temporally, both in magnitude and in direction. In HEP, Total P retention was most commonly negative, indicating net export of P. Over the entire study, $6.35 \mathrm{~mol}$ of $\mathrm{P}$, or $0.20 \mathrm{~kg} \mathrm{P}$ were exported from the pond. In contrast to $\mathrm{P}$, HEP had net retention of $\mathrm{N}\left(\mathrm{as} \mathrm{NO}_{3}{ }^{-}+\mathrm{NH}_{4}{ }^{+}\right)$. A total of $2672 \mathrm{~mol} \mathrm{~N}$, or $37.4 \mathrm{~kg}$ were retained by the pond. Placing this in context, HEP exported $3.09 \mathrm{~g} \mathrm{P} \mathrm{ha}^{-1}$, and trapped $587 \mathrm{~g} \mathrm{~N} \mathrm{ha}^{-1}$ of catchment area. MAT was a net exporter of both phosphorus and nitrogen. Total P export over the duration of the study totaled $54.0 \mathrm{~mol} \mathrm{P}$ (or $1.67 \mathrm{~kg}$ ) and 264 mol N (or $3.7 \mathrm{~kg}$ ). Placed in context, this amounted to a net loss of $34.6 \mathrm{~g} \mathrm{P} \mathrm{ha}^{-1}$ and $76.3 \mathrm{~g} \mathrm{~N}$ $\mathrm{ha}^{-1}$ of catchment area.

Sediment traps were installed in each pond for four of the study's sampling intervals in late summer to autumn. The material captured in sediment traps was quantified, and digested to determine the amount of TP and N deposited in particulate material. These quantities were used to calculate the average flux of $\mathrm{P}$ and $\mathrm{N}$ to sediments $\left(\mathrm{mmol} \mathrm{m}^{-2} \mathrm{~d}^{-1}\right)$, and from these values, the flux of $\mathrm{N}$ and $\mathrm{P}$ to sediments for the entire pond $\left(\mathrm{mol} \mathrm{d}^{-1}\right)$. Material collected in sediment traps 
was highly enriched in N during the first three intervals (Jul. 27 - Sept. 16) for both ponds, with $\mathrm{N}$ :P ranging from 20 to 103 . In each pond, the material tended to be relatively rich in $\mathrm{P}$ during the final interval (Sept. 16 - Nov. 5) with N:P of 4.2 in MAT and 8.6 in HPE.

The differences between flux of $\mathrm{P}$ and $\mathrm{N}$ (from the water column to sediments as particulate matter) and overall retention were calculated to determine internal loading of nutrients, most likely loading from sediments (Table 2.5). Where retention and flux were equivalent, all retention would be explained by flux of particulate $\mathrm{N}$ or $\mathrm{P}$ to sediments. Where flux exceeds retention, the difference is attributed to internal loading. Where flux is less than retention (negative values for loading), a mechanism other than deposition contributes to net retention (e.g., denitrification in the case of $\mathrm{N}$ retention). Internal loading of $\mathrm{P}$ was generally positive for both ponds, and of similar magnitude to $\mathrm{P}$ flux to sediments, suggesting that most of the P deposited to sediments is remineralized and released into the water column, with an average of $22 \%$ of TP buried in HEP, and $26 \%$ buried in MAT sediments during the period of July 14 - Nov 5. Internal nitrogen loading was negative for three of four intervals in HEP. The magnitude of this loss suggests approximately $59 \%$ of nitrogen deposited to sediments as particular matter is subsequently lost, most likely via denitrification. In contrast, internal loading of $\mathrm{N}$ was always positive in MAT, and of the same magnitude as flux of particulate $\mathrm{N}$ to sediments, suggesting that $97 \%$ of nitrogen reaching sediments in particulate form was remineralized and released to the water column as ammonium and nitrate (or nitrite).

TSS loading in both ponds was low and consistent during the majority of the study period (Table 2.5). HEP and MAT experienced a pulse of TSS into the ponds during the mid-summer months (Jul. 27 - Aug. 19). Over the entire study, a total of $1416 \mathrm{mg}$ of TSS was retained in HEP and $1127 \mathrm{mg}$ in MAT. When placing this into the context of catchment areas, HEP 
retained $22.23 \mathrm{mg} \mathrm{TSS} \mathrm{ha}^{-1}$ and MAT retained 23.29 $\mathrm{mg} \mathrm{TSS} \mathrm{ha}^{-1}$. Although both ponds retained TSS over the entire season, it was interesting that they were net exporters of TSS on a daily basis. The daily average export of TSS was higher in MAT, with $101.58 \mathrm{mg} \mathrm{TSS} \mathrm{ha}^{-1} \mathrm{~d}^{-1}$ exported, compared to $66.18 \mathrm{mg}$ TSS ha- $\mathrm{d}^{-1}$ exported in HEP. This finding is not surprising as particles take time to settle and due to the shallow depth of stormwater ponds, generally less than $2 \mathrm{~m}$ deep, bottom sediment can be easily disturbed and resuspended due to strong winds and high inflow, resulting in low or negative retention (He \& Marsalek 2014). Interestingly, there was no significant relationship found between retention of TSS and rainfall entering the ponds (ANCOVA, $\mathrm{f}=3.91, \mathrm{p}=0.0794)$ and this was likely due to the low number of rainfall events during our period of study. 
Table 2.5 Loading, export, and retention of TP, TN, and TSS in HEP and MAT.

\begin{tabular}{|c|c|c|c|c|c|c|c|c|c|c|c|c|c|c|}
\hline & \multicolumn{6}{|c|}{$\mathrm{mol}(\mathrm{P}$ or $\mathrm{N}) \mathrm{d}^{-1} ; \mathrm{mg}(\mathrm{TSS}) \mathrm{d}^{-1}$} & & \multicolumn{7}{|c|}{ Retention $(\mathrm{P}$ or $\mathrm{N}) \mathrm{mol} \mathrm{d}^{-1} ; \mathrm{mg}(\mathrm{TSS}) \mathrm{d}^{-1}$} \\
\hline & \multicolumn{3}{|c|}{ Loading } & \multicolumn{3}{|c|}{ Export } & Hydraulic & \multicolumn{3}{|c|}{ Net retention } & \multicolumn{2}{|c|}{$\begin{array}{c}\text { Flux to } \\
\text { sediments }\end{array}$} & \multicolumn{2}{|c|}{ Internal loading } \\
\hline Hydro East Pond - Total P & $\mathrm{P}$ & $\mathrm{N}$ & TSS & $\mathrm{P}$ & $\mathrm{N}$ & TSS & & $\mathrm{P}$ & $\mathrm{N}$ & TSS & $P$ & $\mathrm{~N}$ & $P$ & $\mathrm{~N}$ \\
\hline April 08 & $1 \overline{0.9}$ & $\overline{498}$ & $\overline{47}$ & $5 . \overline{5} 0$ & 412 & $\overline{117}$ & 3.8 & $5 . \overline{4} 2$ & $8 \overline{6} .0$ & $\overline{-70}$ & & & & \\
\hline April 20 & 0.08 & 49.4 & 49 & 0.51 & 29.9 & 25 & 16.6 & -0.43 & 19.4 & 25 & & & & \\
\hline May 5 & 0.81 & 57.1 & 50 & 0.23 & 59.1 & 25 & 16.7 & -0.59 & -2.04 & 25 & & & & \\
\hline May 12 & 0.25 & 31.5 & 31 & 0.99 & 43.4 & 16 & 13.1 & -0.74 & -11.9 & 16 & & & & \\
\hline May 31 & 0.55 & 15.6 & 17 & 0.41 & 14.4 & 17 & 20.5 & 0.14 & 1.14 & 0 & & & & \\
\hline June 7 & 2.17 & 62.9 & 66 & 2.91 & 59.7 & 33 & 11.3 & -0.74 & 3.14 & 33 & & & & \\
\hline July 8 & 0.44 & 17.8 & 27 & 0.89 & 15.2 & 18 & 42.1 & -0.44 & 2.64 & 9 & & & & \\
\hline July 27 & 5.57 & 64.6 & 136 & 4.36 & 41.6 & 90 & 8.5 & 1.21 & 22.9 & 45 & 0.31 & 6.28 & -0.90 & -16.6 \\
\hline August 19 & 3.27 & 179 & 296 & 3.85 & 50.5 & 413 & 4.1 & -0.58 & 128 & -117 & 0.60 & 61.0 & 1.18 & -67.0 \\
\hline September 16 & 0.89 & 56.4 & 33 & 0.84 & 21.0 & 33 & 10.4 & 0.05 & 35.4 & 0 & 0.64 & 65.8 & 0.59 & 30.4 \\
\hline November 05 & 0.29 & 144 & 47 & 0.51 & 111 & 47 & 7.6 & -0.22 & 32.2 & 0 & 0.55 & 4.73 & 0.77 & -27.5 \\
\hline December 12 & 0.37 & 125 & 30 & 0.71 & 77.4 & 30 & 11.8 & -0.34 & 47.3 & 0 & & & & \\
\hline \multicolumn{7}{|c|}{ Whole study Total P retention $(\mathrm{mol})=\mathbf{- 6 . 3 5}$} & \multicolumn{8}{|c|}{ Whole study Total $\mathrm{N}$ retention $\left(\mathrm{NH}_{4}^{+}+\mathrm{NO}_{3}{ }^{-}\right)(\mathrm{mol})=\mathbf{2 6 7 2}$} \\
\hline & \multicolumn{3}{|c|}{ Loading } & \multicolumn{3}{|c|}{ Export } & $\begin{array}{l}\text { Hydraulic } \\
\text { Retention } \\
\text { time (d) }\end{array}$ & \multicolumn{3}{|c|}{ Net retention } & \multicolumn{2}{|c|}{$\begin{array}{l}\text { Flux to } \\
\text { sediments }\end{array}$} & \multicolumn{2}{|c|}{ Internal loading } \\
\hline Mattamy Pond - Total P & $\underline{\mathrm{P}}$ & $\underline{\mathrm{N}}$ & $\underline{\mathrm{TSS}}$ & $\underline{\mathrm{P}}$ & $\underline{\mathrm{N}}$ & $\underline{\mathrm{TSS}}$ & & $\underline{\mathrm{P}}$ & $\underline{\mathrm{N}}$ & $\underline{\mathrm{TSS}}$ & $\underline{\mathrm{P}}$ & $\underline{\mathrm{N}}$ & $\underline{\mathrm{P}}$ & $\underline{\mathrm{N}}$ \\
\hline April 08 & $6 . \overline{4} 9$ & $\overline{142}$ & $\overline{59}$ & $7 . \overline{9} 9$ & $9 \overline{9.5}$ & $\overline{142}$ & 6.6 & $-1 . \overline{50}$ & $4 \overline{2.1}$ & $\overline{-83}$ & & & & \\
\hline April 20 & 0.21 & 11.6 & 30 & 0.14 & 8.65 & 25 & 34.2 & 0.07 & 2.94 & 5 & & & & \\
\hline May 5 & 1.40 & 71.2 & 25 & 0.59 & 99.8 & 25 & 33.4 & 0.81 & -28.6 & 0 & & & & \\
\hline May 12 & 0.48 & 11.6 & 24 & 1.53 & 23.0 & 16 & 27.7 & -1.05 & -11.4 & 8 & & & & \\
\hline May 31 & 0.86 & 4.64 & 39 & 0.76 & 4.35 & 26 & 49.5 & 0.10 & 0.29 & 13 & & & & \\
\hline June 7 & 2.89 & 10.4 & 50 & 4.38 & 9.55 & 33 & 27.5 & -1.49 & 0.87 & 17 & & & & \\
\hline July 8 & 1.07 & 8.95 & 20 & 1.15 & 4.38 & 20 & 94.9 & -0.08 & 4.57 & 0 & & & & \\
\hline July 27 & 4.72 & 13.7 & 103 & 4.68 & 10.7 & 69 & 19.4 & 0.05 & 2.96 & 34 & 0.51 & 45.6 & 0.46 & 42.6 \\
\hline August 19 & 7.06 & 26.1 & 225 & 5.79 & 26.3 & 314 & 8.9 & 1.27 & -0.13 & -89 & 1.09 & 89.0 & -0.19 & 89.1 \\
\hline September 16 & 0.30 & 15.4 & 25 & 0.65 & 13.3 & 25 & 26.0 & -0.35 & 2.12 & 0 & 0.98 & 64.1 & 1.33 & 62.0 \\
\hline November 05 & 0.45 & 44.7 & 54 & 0.54 & 44.6 & 36 & 17.6 & -0.08 & 0.11 & 18 & 0.75 & 3.14 & 0.83 & 3.03 \\
\hline December 12 & 0.60 & 23.2 & 23 & 0.64 & 19.6 & 23 & 27.3 & -0.04 & 3.60 & 0 & & & & \\
\hline $\begin{array}{l}\text { Whole study Total P retenti } \\
\text { Whole study Total TSS rete }\end{array}$ & $\begin{array}{l}(\mathrm{mol}) \\
\text { on }(\mathrm{m}\end{array}$ & $=\begin{array}{l}-5 \\
=\end{array}$ & $\begin{array}{l}9 \\
127\end{array}$ & & & & & & rete & $(\mathrm{Nl}$ & $\mathrm{NO}_{3}$ & ol) $=$ & -264 & \\
\hline
\end{tabular}




\subsubsection{Sediment Traps}

The sedimentation rates were similar between ponds over most of the study, although higher rates were seen in MAT between July 14 and July 27 (Fig. 2.6). The annual average sedimentation rate $\left(\mathrm{mm} \mathrm{y}^{-1}\right)$ in HEP was $51.1 \pm 6.0$ and $65.7 \pm 12.3$ in MAT. Although there have not been any studies on sediment deposition rates in stormwater ponds, studies by Marsalek \& Marsalek (1997) and Yousef et al. (1994) measured sediment accumulation rates in stormwater ponds which are comparable to deposition rates (Szmytkiewicz \& Zalewska 2014). Marsalek \& Marsalek (1997) estimated the rate of accumulation in a stormwater pond in Kingston, Ontario to be $20 \mathrm{~mm} \mathrm{y}^{-1}$ and Yousef et al. (1994) measured sediment accumulation rates in nine different ponds in Florida and the rates ranged from 10.3 to $42.0 \mathrm{~mm} \mathrm{y}^{-1}$.

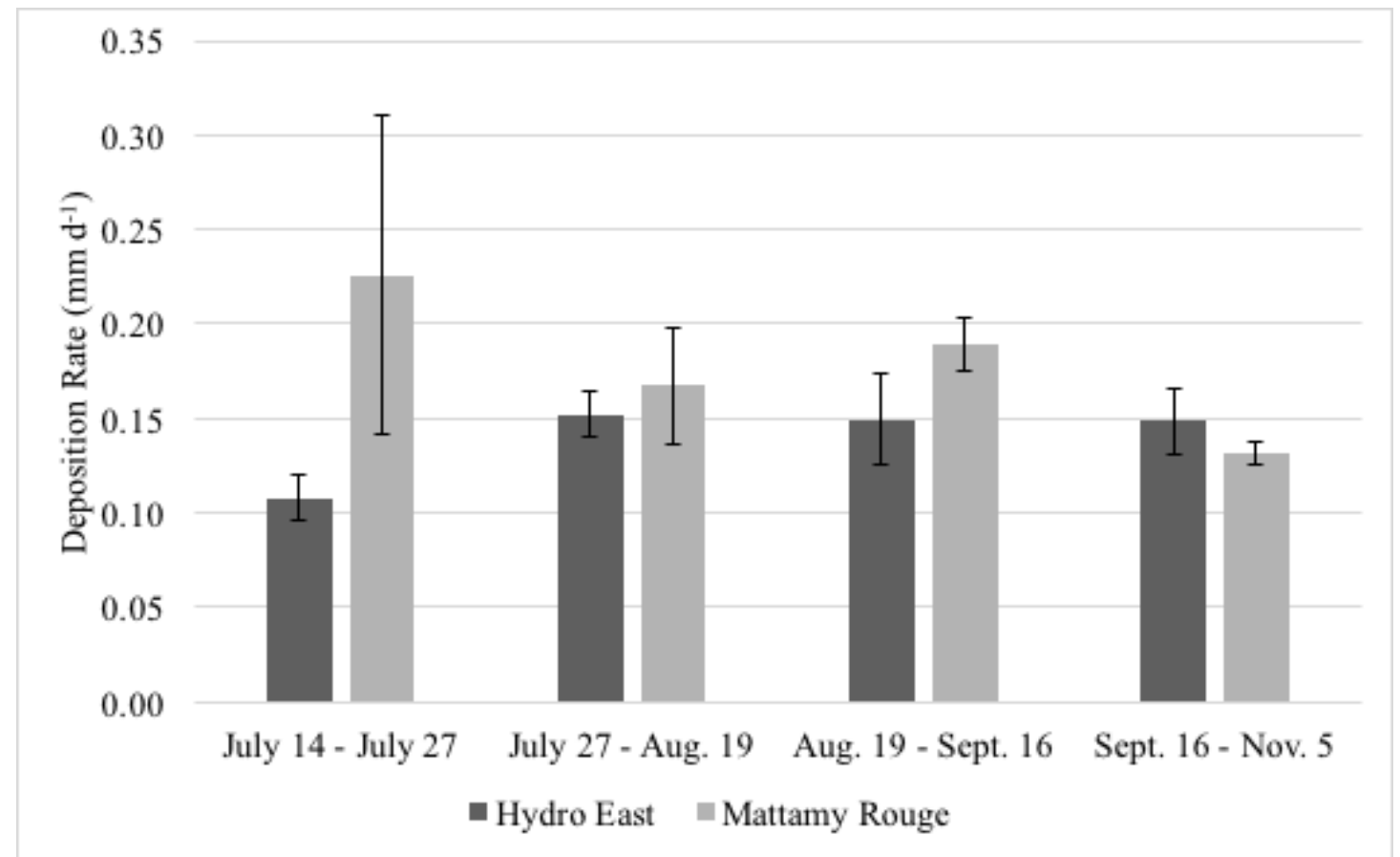

Fig. 2.6 Sediment deposition rates $\left(\mathrm{mm} \mathrm{day}^{-1}\right)$ from sediment traps in HEP and MAT.

As for the material composition, the majority $(>80 \%)$ of the material being deposited in HEP and MAT was inorganic. This was reflective of the material composition of bottom 
sediment in both ponds, as the bottom sediment was $92 \%$ and $93 \%$ inorganic in HEP and MAT, respectively. Overall, a higher percentage of organic phosphorus was being deposited in MAT than in HEP (Fig. 2.7). An increase in deposition of organic phosphorus was observed beginning late summer into autumn, which likely reflects the settling of dead biomass. A recent study by Song et al. (2017) observed that the high rate of accumulation of organic phosphorus in sediment from primary production due to external phosphorus loading could lead to internal P release through decomposition or other biological processes in urban stormwater ponds.

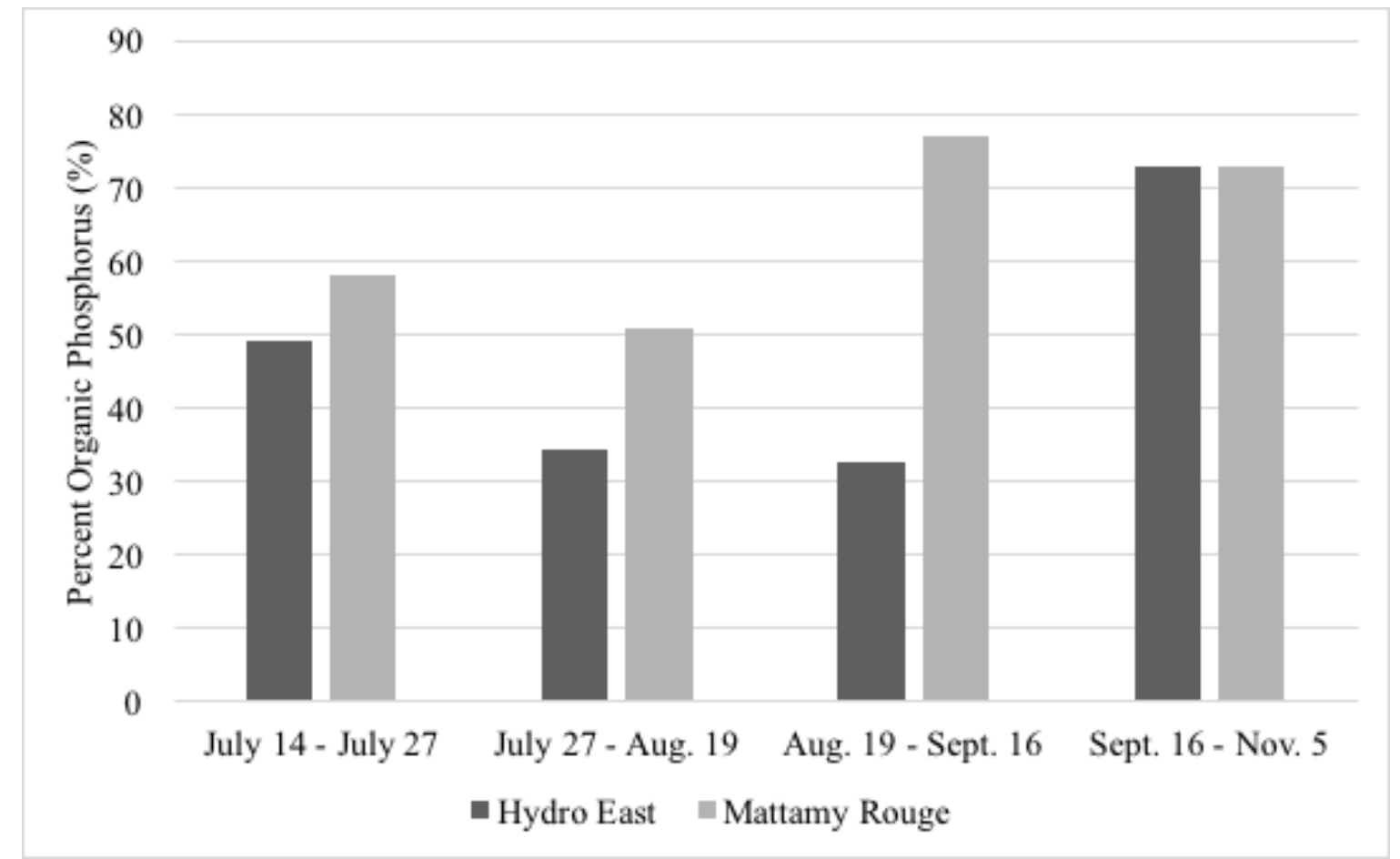

Fig. 2.7 Percent organic phosphorus in sediment collected from sediment traps in HEP and MAT.

\subsubsection{Nutrient Budget Model}

Higher phosphorus loading was observed in MAT compared to HEP and the reverse was seen for nitrogen loading (Fig. 2.8). Internal loading of TP was observed in both ponds due to the remineralization of $\mathrm{P}$ deposited in sediment and release into the water column. Although there was a higher loading of inorganic nitrogen in HEP compared to MAT, HEP retained 
higher amounts of inorganic nitrogen and exported less than MAT over the sampling season.

This retention was likely due to loss of inorganic nitrogen via denitrification. In contrast, there was internal loading of inorganic nitrogen in MAT from remineralization and release to the water column from sediment.

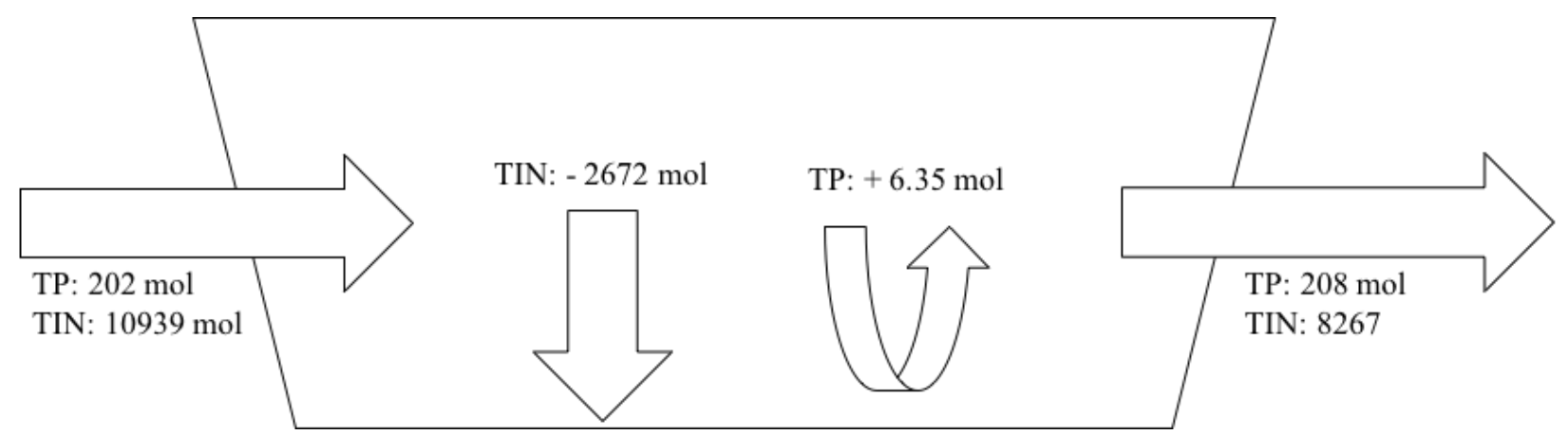

a) Nutrient budget for HEP.

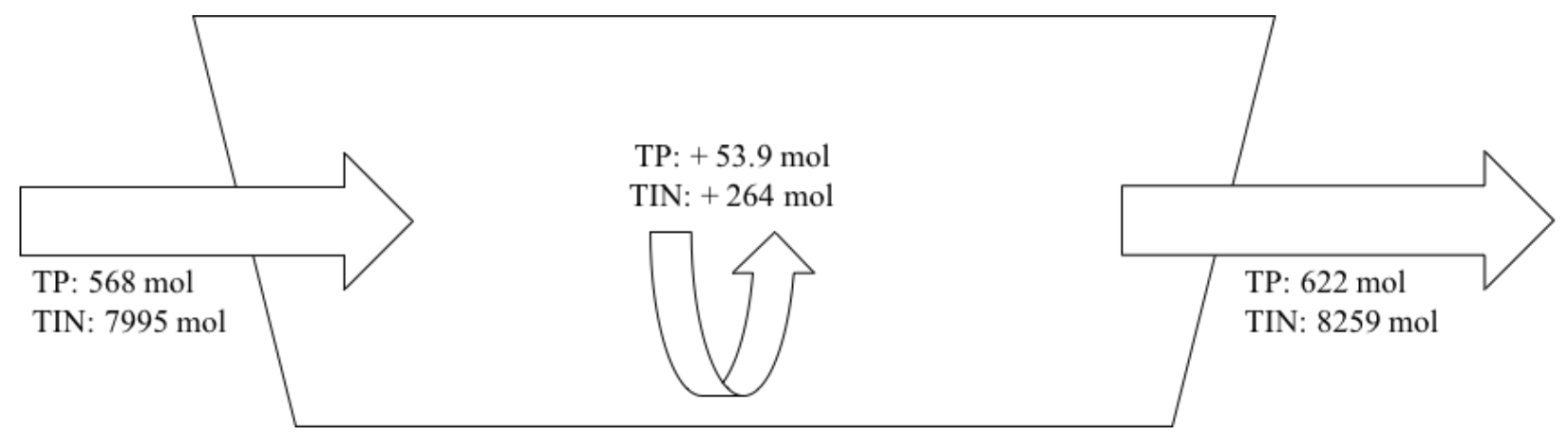

b) Nutrient budget for MAT.

Fig. 2.8 Nutrient budgets for HEP and MAT over the entire sampling season in 2016. The total amount loading and washout of TP and TIN was used to calculate retention/internal loading. Arrows pointing down with negative values represent retention and curved up arrows with positive values represent internal loading of each nutrient constituent.

Stormwater ponds have been widely constructed in North American cities to reduce and delay peak flows from urban runoff and have also been recognized for their potential ability to retain pollutants, such as nutrients and TSS. The results from this study have demonstrated that these retention ponds are able to provide retention of TSS but can be exporters of phosphorus and nitrogen. This is in contrast to previous studies in the literature, which have reported retention efficiencies of phosphorus between $12 \%$ and $57 \%$ and retention efficiencies of 
nitrogen between 6\% and 84\% (Mayer et al. 1996; Wu et al. 1996; Borden et al. 1998; Comings et al. 2000; Mallin et al. 2002; Winston et al. 2013). However, it important to highlight that 2016 in Toronto, Ontario, was an abnormally dry and hot year and stratification was observed in HEP and MAT in early summer. Due to the dry year, concentrations of phosphorus and nitrogen loading were generally found to be low in HEP and MAT. When looking into percent retention, low concentrations can give the illusion that ponds perform poorly. For example, if there is a loading of $0.1 \mathrm{~mol}$ of phosphorus, a $10 \%$ retention of 0.01 mol may appear low. But when putting it into context, the initial loading was already low and further reduction may be difficult due to recalcitrant material. A common misconception is that stormwater ponds do not experience thermal stratification as they are well mixed due to their shallow depth and short residence time (Persson 2000; Zoppou 2001). But stratification was observed in HEP and MAT, consistent with findings from other ponds studied in Ontario, Canada (McEnroe et al. 2013; Song et al. 2013) and when stratification does occur, it may lead to a release of iron-bound phosphate and ammonium from the sediment. Much more work is needed to investigate how biogeochemical cycles function and may be altered in stormwater ponds.

Overall, this study and previous studies have shown that stormwater ponds have the ability to provide retention of pollutants from urban runoff. However, during particularly dry years, these ponds may become net exporters of nutrients. The results from this study have shown that the function of these ponds should be enhanced to provide further treatment before the water flows into receiving bodies of water. One potential solution may be to increase the depth of these ponds. But as discussed above, these ponds already experience thermal stratification with their shallow depth and an increase in depth may further add to this problem. However, instead 
of building ponds with greater depths, sediment in ponds should be periodically removed to maintain their effective depth and also to prevent potential internal loading from the release of phosphorus from sediment into the water column. 


\section{Conclusion}

Two stormwater ponds in Toronto, Ontario, Canada were evaluated for their nutrient and TSS retention ability over a period of eight months. The following conclusions were drawn from this study:

1) Nutrient concentrations between the studied ponds were found to be similar, with the exception of $\mathrm{NO}_{3}{ }^{-}$, as concentrations of $\mathrm{NO}_{3}{ }^{-}$were higher in HEP than in MAT. Despite the difference, $\mathrm{NO}_{3}{ }^{-}$concentrations in both ponds were higher than those reported in other studies in the literature. The dry year and low flushing may have played a role in high $\mathrm{NO}_{3}{ }^{-}$concentrations.

2) Over the entire sampling period, the seasonal trends for $\mathrm{TP}, \mathrm{DRP}, \mathrm{NH}_{4}{ }^{+}$, and $\mathrm{NO}_{3}{ }^{-}$were similar between HEP and MAT. TP and DRP concentrations were highest during midsummer and may have been caused by the release of iron-bound phosphate from the sediment due to anoxic conditions resulting from stratification. Concentrations of $\mathrm{NH}_{4}{ }^{+}$ were highest during late spring, likely due to external loading from the spring flush, and were lowest during early to mid-summer, likely due to a combination of biological uptake and nitrification. Similar to $\mathrm{NH}_{4}{ }^{+}$, concentrations of $\mathrm{NO}_{3}{ }^{-}$were highest during early spring, likely due to the spring flush. However, concentrations of $\mathrm{NO}_{3}{ }^{-}$decreased rapidly as it was probable that higher denitrification rates occurred with increased temperatures.

3) Retention of nutrients varied temporally, both in magnitude and in direction. Both HEP and MAT were net exporters of phosphorus over the entire season, with $-6.35 \mathrm{~mol}$ and 53.9 mol exported, respectively. However, HEP had net retention of $2672 \mathrm{~mol}$ of nitrogen, while MAT exported 264 mol of nitrogen over the entire study. 
4) Internal loading of phosphorus was generally positive for both ponds, suggesting that most of the phosphorus deposited to sediments was remineralized and released into the water column. In HEP, $56 \%$ of the nitrogen was deposited to sediments as particulate matter and lost, most likely through denitrification. In contrast, 97\% of nitrogen deposited to sediment in MAT was remineralized and released to the water column as ammonium and nitrate (and nitrite).

5) A total of $1416 \mathrm{mg}$ and $1127 \mathrm{mg}$ of TSS was retained in HEP and MAT, respectively.

6) The annual average sedimentation rate $\left(\mathrm{mm} \mathrm{y}^{-1}\right)$ in HEP was $51.1 \pm 6.0$ and $65.7 \pm 12.3$ in MAT.

7) The majority of material being deposited in HEP and MAT, was inorganic in nature.

This study has demonstrated that stormwater ponds have the ability to provide retention of nutrients and TSS, but their function may be enhanced. Pond depth may be one factor in improving pond function. However, as shown in this study, stratification already occurs in these shallow ponds and increasing the depth physically may not be the real solution. Instead, sediment in ponds should be periodically removed to maintain their effective depth and also to prevent potential internal loading from the release of phosphorus from sediment into the water column. More studies should focus on the relationship between sediment accumulation and effective pond volume on nutrient retention. The results from this study also showed that during an anomalously dry year, these ponds may become net exporters of nutrients. Further research should be done to examine and compare how these ponds would function during an anomalously wet year (e.g. 2017) to determine how much of the results found from this study was driven by the lack of rainfall. As stormwater ponds have been widely built in many municipalities as water management infrastructures, there is a need for a model synthesizing 
the data from literature on stormwater ponds to better understand their function. For example, a model could be created to predict retention as a function of local climate, catchment characteristics, and pond hydrologic/morphologic characteristics. As the building of stormwater ponds comes at a cost of alternative land uses, such a model could help local water managers determine if these ponds are worth building and if any special designs or features are needed to ensure that the ponds will function as expected 


\section{Appendices}

\section{Appendix A: Map of Location and Proximity of Hydro East and Mattamy Rouge Ponds}

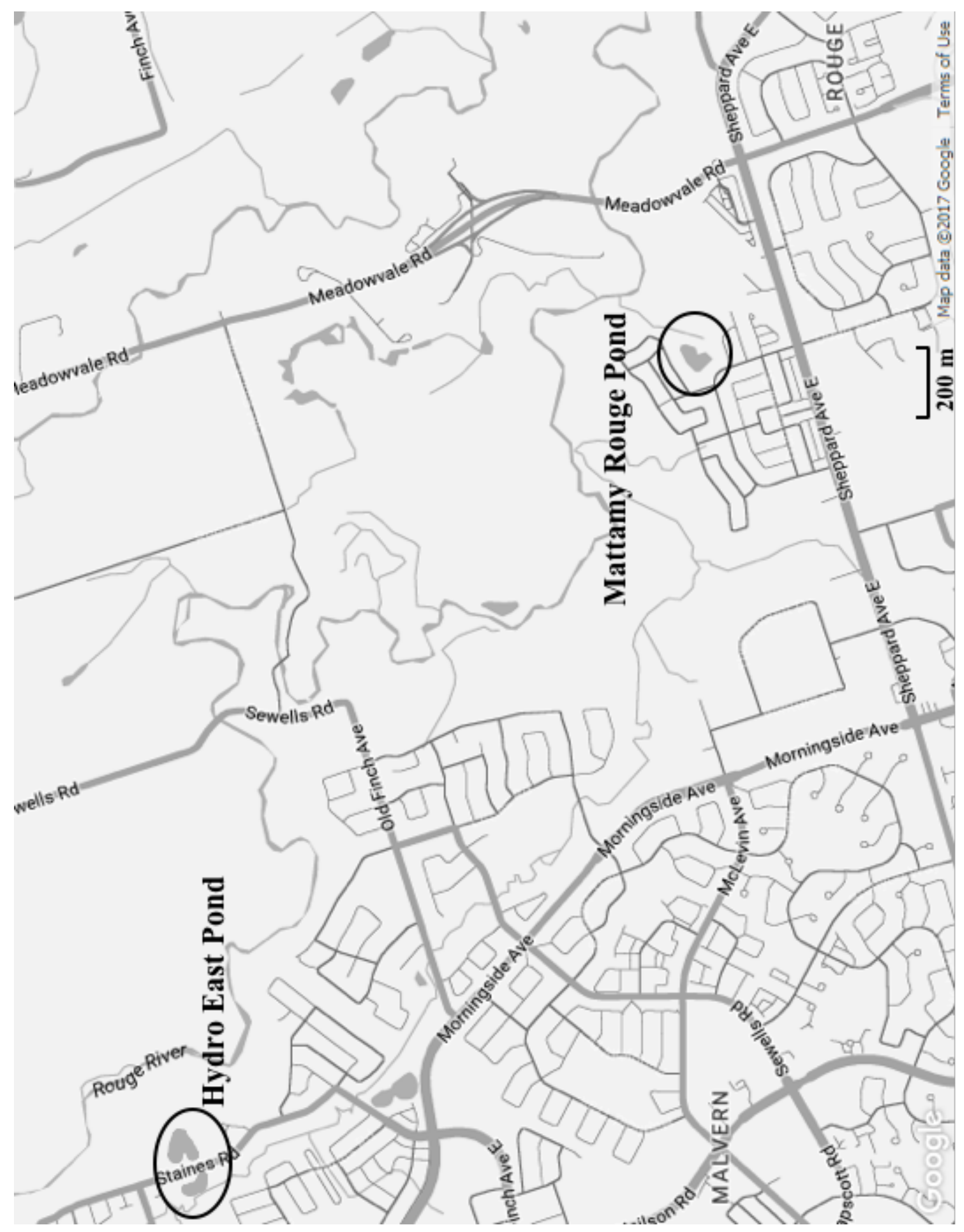




\section{Appendix B: Site Drawing of Hydro East Pond}

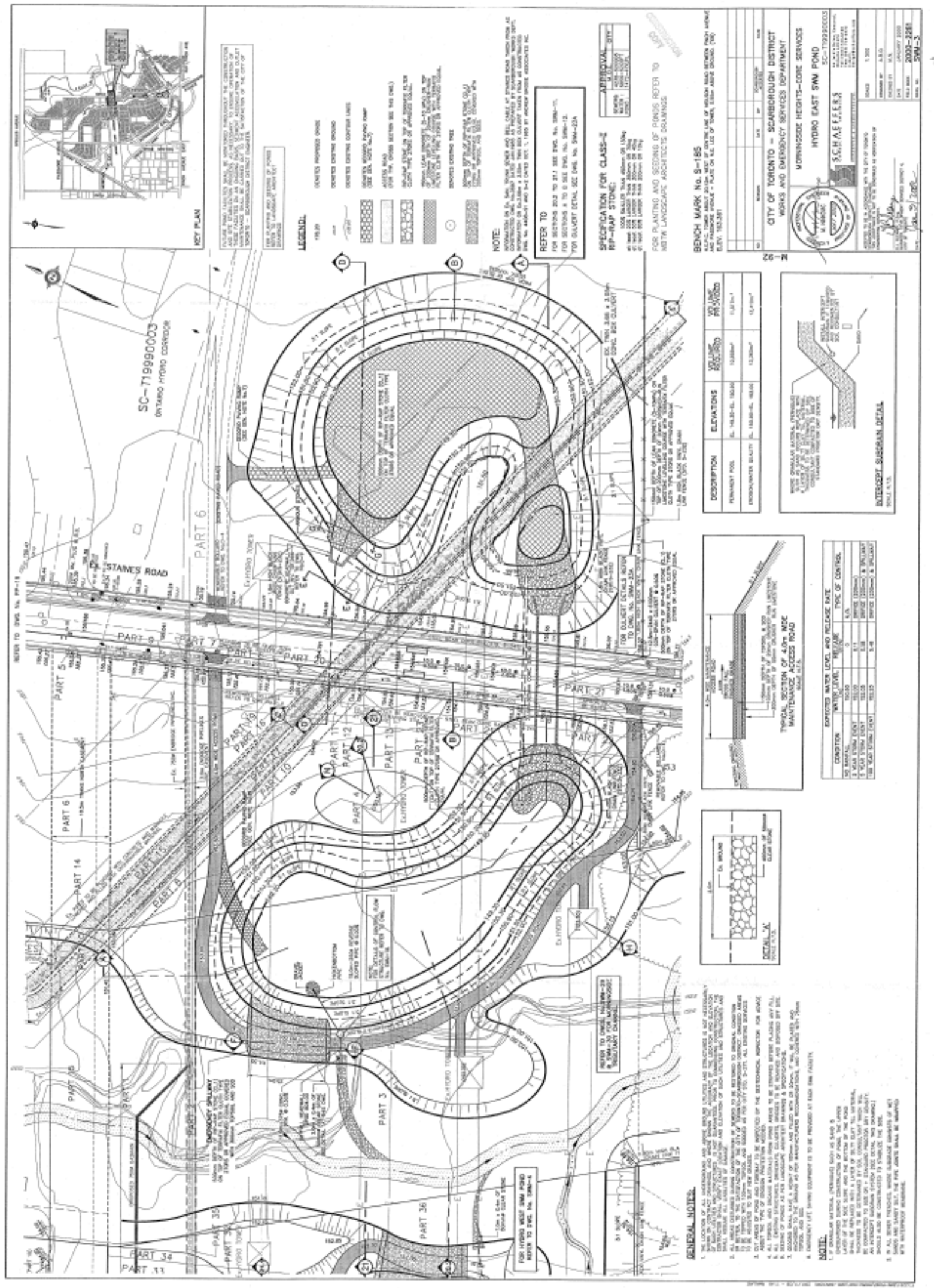




\section{Appendix C: Site Drawing of Mattamy Rouge Pond}

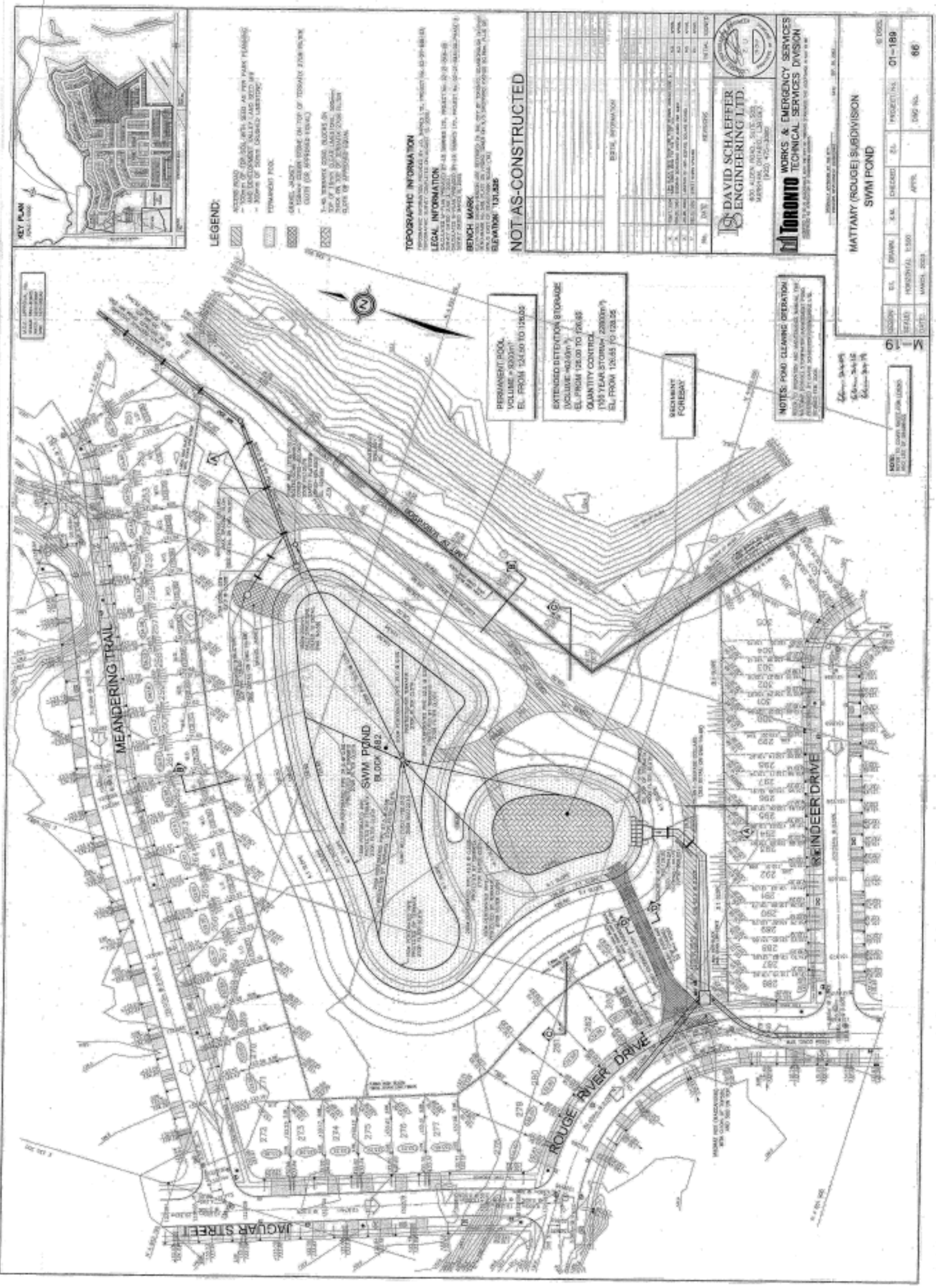




\section{Appendix D: Extended Methods}

\section{Secchi Depth}

A Secchi disk was used to measure the water clarity of the pond. A Secchi disk is a flat, weighted disk with alternating black and white quadrants. The following technique used was developed by Angelo Secchi in 1866 (Preisendorfer 1986).

1. The Secchi disk was lowered slowly into the water column until all four quadrants were no longer visible. This depth was recorded.

2. The disk was then slowly raised until all quadrants just become visible again. This depth was also recorded and averaged with the first recorded depth to obtain the Secchi depth.

3. Secchi depth measurements were made at three locations (A, B, and C) in each pond (Fig. 2.2).

\section{Sediment Mapping}

First Approach

1. Depths of the water column to sediment were measured at various points along transects depicted in Fig. 2.2.

2. A measuring tape attached to a weighted disk was lowered to the bottom of the pond. With the disk lying flat on the sediment surface, the depth of the water column was measured at each point (18 points total in HEP, 16 points total in MAT).

3. The distance was measured from a fixed point on shore (above the water line) to the water surface on each date, and this value was added to the depth of the water column to determine depth to the sediments at each location relative to a fixed point on shore (Fig. 2.2). This 
measurement allowed for observations regarding any loss or gain of sediment throughout the pond over the sampling period.

4. Linear regression was used to determine rate of sediment accumulation for each sampling location over the duration of the study, and the average rate of accumulation throughout the pond was determined based on mean of all site-specific regression coefficients.

\section{Second Approach}

1. Sediment accumulation was also measured by inserting a pole vertically into the sediment until it was no longer possible to push, and reading the total depth.

2. The thickness of sediment was then determined by taking the difference between this observed value and the water column depth at each location.

1. Distance from Fixed Point to Sediment Surface $=$ Fixed Point to Water Surface + Depth of Water Column

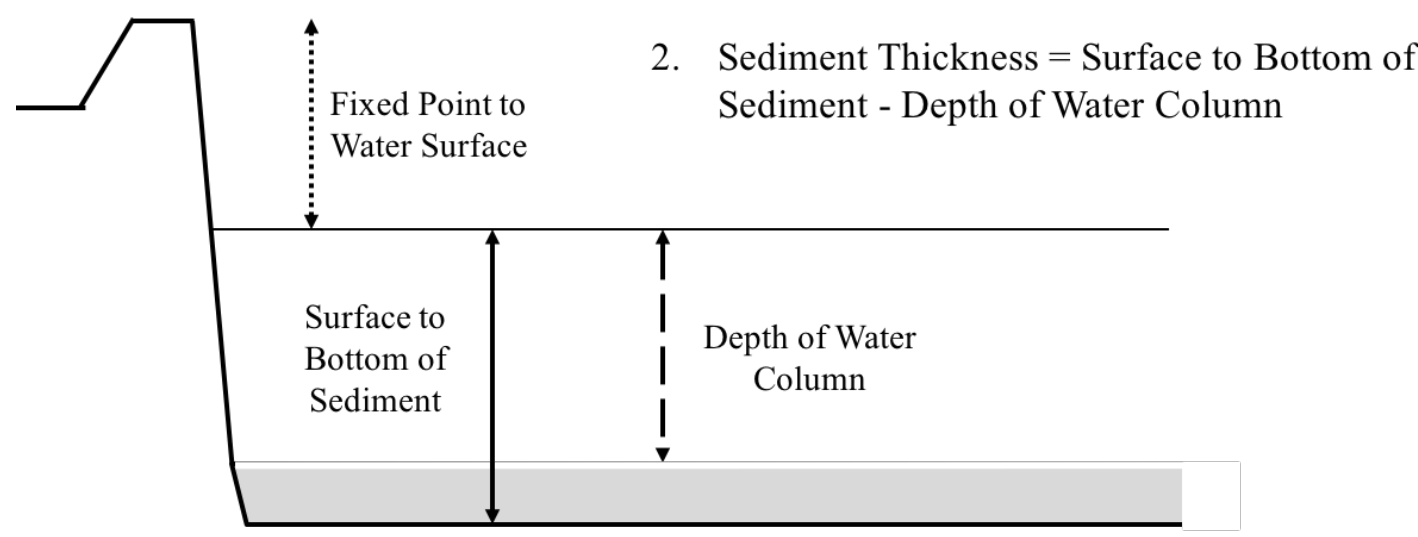

Figure D1 Measurement of water depth and sediment thickness. 


\section{Analysis of Organic Matter in Sediment Samples}

1. Organic matter in sediment samples was determined by the ignition method (Howard and Howard 1990).

2. A sample ( $\sim 0.5 \mathrm{~g})$ of dried sediment $\left(105^{\circ} \mathrm{C}\right.$ for 12 hours $)$ was sieved ( $\left.2 \mathrm{~mm} \mathrm{mesh}\right)$, and weighed into ceramic crucibles (pre-weighed, pre-ashed).

3. The samples were then placed into a muffle furnace and were ignited at $550^{\circ} \mathrm{C}$ for 2 hours, cooled, and re-weighed.

4. The percent organic matter in the sediment was calculated using the following equation:

$$
\% \text { Organic Matter }=\frac{(\text { Pre }- \text { ignition mass })-(\text { Post }- \text { ignition mass })}{(\text { Pre }- \text { ignition weight })} \times 100
$$

\section{Analysis of Total Suspended Solids (TSS)}

1. The weight of pre-ashed $\left(550^{\circ} \mathrm{C}\right.$ for 4 hours $)$ Whatman $\mathrm{GF} / \mathrm{F}$ filters $(0.7 \mu \mathrm{m})$ was measured before each was used for the filtering of water samples, to obtain the original filter paper weights.

2. The filter papers were placed into a filtration apparatus and were first wet with milliQ water.

3. Aliquots of water were filtered through a filtration apparatus.

4. The filters were then dried in an oven for $12-\mathrm{hrs}$ at $105^{\circ} \mathrm{C}$.

5. The dried filter papers were cooled and weighed. The concentration of TSS was calculated using the following equation:

$$
m g \text { Suspended Solids } L^{-1}=\frac{(\text { mass of filter with dried residue }- \text { mass of filter }) \times 100}{m L \text { Sample }}
$$




\section{Nutrient Analyses of Water Samples}

Dissolved Reactive Phosphorus (DRP) - Ascorbic Acid Method

1. DRP concentrations were measured in filtered water samples using the Ascorbic Acid Method (Murphy and Riley 1962).

2. Aliquots of 5-mL of sample water were transferred into a clean, dry test tubes.

3. 1 drop of phenolphthalein indicator solution was added into each test tube.

4. If a red colour developed, $2.5 \mathrm{M} \mathrm{H}_{2} \mathrm{SO}_{4}$ solution was added dropwise to discharged the colour.

5. 0.8-mL of combined reagent (Murphy and Riley 1962) was added into each test tube and were mixed thoroughly.

6. All test tubes containing the mixed sample and reagent were left at room temperature for at least 10 minutes for colour to develop.

7. The absorbance of each sample at $880-\mathrm{nm}$ was then measured on a UV/VIS spectrophotometer (Perkin Elmer Lambda 20).

Total Reactive Phosphorus

1. Total reactive phosphorus concentrations were measured in unfiltered water samples using the Ascorbic Acid Method (Murphy and Riley 1962), as described above.

Total Phosphorus (TP)

1. The water samples were first digested using the Persulfate Digestion Method to oxidize organic material and release phosphorus as orthophosphate (American Public Health Association 2012). 
2. Aliquots of $25-\mathrm{mL}$ of sample water were transferred into borosilicate glass bottles.

3. 1 drop of phenolphthalein indicator solution was added into each bottle.

4. If a red colour developed, $\mathrm{H}_{2} \mathrm{SO}_{4}$ solution (American Public Health Association 2012) was added dropwise to discharge the colour.

5. Then $0.5-\mathrm{mL}$ of $\mathrm{H}_{2} \mathrm{SO}_{4}$ solution and $0.25-\mathrm{g}$ of $\mathrm{K}_{2} \mathrm{~S}_{2} \mathrm{O}_{8}$ were added into each bottle.

6. The samples were then heated in an autoclave at 98 to $137 \mathrm{kPa}$ for 30 minutes.

7. Once cool, 1 drop of phenolphthalein indicator solution was added into each bottle and neutralized to a faint pink colour with $6 \mathrm{M} \mathrm{NaOH}$.

8. The phosphorus concentrations were then determined by the Ascorbic Acid Method (Murphy and Riley 1962), as described above. A separate calibration curve was constructed with standards which had undergone the persulfate digestion procedure.

\section{Ammonium}

1. Ammonium concentrations were measured using a modification of the Phenate Method (Solórzano 1967). During the presence of hypochlorite, ammonia found in the samples reacts with phenate and produces a blue colour. Sodium nitroferricyanide was used as a catalyst for this reaction.

2. Aliquots of 5-mL of sample water were transferred into clean, dry test tubes.

3. The following reagents were added to each test tube in sequence and mixed: $0.2-\mathrm{mL}$ of phenol solution, $0.2-\mathrm{mL}$ of sodium nitroferricyanide, and $0.5-\mathrm{mL}$ of oxidizing solution (Solórzano 1967).

4. Samples with reagents were then capped and allowed to stand for one hour in the dark.

5. The absorbance of each sample at 640-nm was then measured on a UV/VIS spectrophotometer (Perkin Elmer Lambda 20). 
Nitrate

1. Nitrate concentrations were determined using the Cadmium Reduction Method (Wood et al. 1967).

2. Aliquots of $2.5-\mathrm{mL}$ of sample was transferred into clean, dry test tubes and $7.5-\mathrm{mL}$ of ammonium chloride-EDTA solution (Wood et al. 1967) was added into each test tube and mixed.

3. Samples were then passed through a reduction column, packed with copper-cadmium granules, using a peristaltic pump.

4. As the samples were passed through the reduction column, the first 5-mL of each sample were discarded and the next 2-mL was collected into a clean, dry test tube.

5. 0.1-mL of colour reagent was then added into each test tube and mixed.

6. Samples were left at room temperature for at least 15 minutes to allow for colour development.

7. The absorbance of each sample at 543-nm was then measured on a UV/VIS spectrophotometer (Perkin Elmer Lambda 20).

\section{Extraction of Pore Water from Sediment Samples and Nutrient Analyses}

1. To obtain the pore water from sediment, sediment samples were centrifuged at $5000 \mathrm{rpm}$ for 15 minutes and the supernatant was decanted to obtain the pore water sample.

2. Pore water samples were analyzed for DRP, ammonium, and nitrate using the methods described above for analyses of water sample. 


\section{Nutrient Analyses of Sediment Samples}

Total Phosphorus (TP)

1. Total phosphorus concentrations in sediment were determined by ignition and extraction with 1 M hydrochloric acid (Aspila et al. 1976).

2. 0.5 -g of oven-dried, sieved sediment samples were weighed and transferred into ceramic crucibles.

3. The samples were then placed into a muffle furnace and were ignited at $550^{\circ} \mathrm{C}$ for 2 hours.

4. Once samples cooled, they were transferred into $200-\mathrm{mL}$ flasks.

5. 50-mL of $1 \mathrm{M}$ hydrochloric acid was added into each flask.

6. The solutions were shaken for 16 hours on a benchtop shaker at room temperature.

7. Aliquots of each mixture sample were transferred into $15-\mathrm{mL}$ centrifuge tubes and centrifuged at $5500 \mathrm{rpm}$ for 15 minutes.

8. The supernatant of each sample was used to determine total phosphorus concentrations by the Ascorbic Acid Method (Murphy and Riley 1962), as described above.

Organic Phosphorus (OP)

1. Organic phosphorus concentrations in sediment were determined from the difference between phosphorus extracted with $1 \mathrm{M}$ hydrochloric acid in unignited (inorganic phosphorus fraction) and ignited (total phosphorus) sediment samples.

2. The procedure to determine the inorganic phosphorus concentrations in sediment was the same as the one for TP, except dried sediment samples were not ignited at $500^{\circ} \mathrm{C}$. 


\section{Bioavailable Phosphorus (BAP)}

1. Bioavailable phosphorus concentrations in sediment were determined by a $\mathrm{NaOH}$ extraction scheme (Burrus et al. 1990).

2. 0.2-g of oven-dried, sieved sediment samples were weighed and transferred into 50-mL centrifuge tubes.

3. 20-mL of $1 \mathrm{M}$ sodium hydroxide was added into each tube and the mixtures were shaken for 16 hours on a benchtop shaker at room temperature.

4. The samples were then centrifuged at $5000 \mathrm{rpm}$ for 15 minutes.

5. $10-\mathrm{mL}$ of the supernatant from each sample was transferred into $15-\mathrm{mL}$ centrifuge tubes and 4-mL of 3.5 M hydrochloric acid was added into each tube.

6. The solutions were then allowed to stand for 16 hours at room temperature to settle organic particles.

7. After 16 hours, samples were centrifuged at $5500 \mathrm{rpm}$ for 15 minutes.

8. The supernatant of each sample was used to determine bioavailable phosphorus concentrations by the Ascorbic Acid Method (Murphy and Riley 1962), as described above.

\section{Total Nitrogen (TN)}

1. The supernatant extracted for TP analysis of sediment was also used for analysis of TN.

2. Aliquots of 4-mL of sample water were transferred into a clean, dry test 50-mL centrifuge tubes.

3. TN concentrations were measured on a Teledyne Tekmar Apollo 9000 Combustion TOC/TN Analyzer. 


\section{Calculation for Concentrations of Nutrient Constituents in Sediment Samples}

The amount of each phosphorus and nitrogen constituent measured in sediment samples was calculated using the following equation:

$$
\text { Concentration of } P / N\left(\mathrm{mg} \mathrm{kg}^{-1}\right)=\frac{\text { Conc. of } P / N\left(\mathrm{mg} \mathrm{L}^{-1}\right) \times \text { Volume of Extractant }(L)}{\text { Mass of Soil }(\mathrm{kg})}
$$

\section{Calculation for Conversion of Sediment Concentrations from $\mathrm{mg} \mathrm{kg}^{-1}$ to mol $\mathrm{L}^{-1}$}

1. Average sediment thickness of each pond was determined by taking the difference between the average depth to bottom of sediment and the average depth to the top of sediment from all points sampled in the entire season.

2. Total volume of bottom sediment in each pond was determined by multiplying the surface area of the pond by the average sediment thickness of the season.

3. Given the total volume of the pond, the mass of sediment in each pond was determined by the following equation, assuming bulk density of the sediment to be $1.3 \mathrm{~g} \mathrm{~mL}^{-1}$ :

$$
\rho_{b}=\frac{M}{V}
$$

where, $\rho_{b}$ is the bulk density, $\mathrm{M}$ is the mass of sediment, and $\mathrm{V}$ is the total volume of sediment.

4. Given the mass and volume of sediment, concentrations from $\mathrm{mg} \mathrm{P} \mathrm{kg}^{-1}$ sediment was converted into mol $\mathrm{P} \mathrm{L}^{-1}$ sediment. 


\section{Appendix E: Secchi Depth Measurements}

All values expressed as centimeter.

Hydro East Pond

\begin{tabular}{|c|c|c|c|c|c|c|c|c|c|c|c|c|}
\hline Location & 08-Apr & 20-Apr & 05-May & 12-May & 01-Jun & 07-Jun & 15-Jun & 08-Jul & 27-Jul & 19-Aug & 16-Sep & 05-Nov \\
\hline A & 62 & 48.5 & 45 & 29 & 45 & 29 & 39 & - & 36 & 40 & 30 & 29 \\
\hline $\mathrm{B}$ & 63 & 44 & 45 & 29 & 44 & 32 & 30 & - & 39 & 40 & 30 & 34 \\
\hline $\mathrm{C}$ & 64 & 39.5 & 41 & 29 & 42 & 28 & 30 & - & 37 & 39 & 26 & 35 \\
\hline Mean & 63 & 44 & 43.7 & 29 & 43.7 & 29.7 & 33 & - & 37.3 & 39.7 & 28.7 & 32.7 \\
\hline Std. Err. & 0.33 & 1.50 & 0.77 & 0.00 & 0.51 & 0.69 & 1.73 & - & 0.51 & 0.19 & 0.77 & 1.07 \\
\hline
\end{tabular}

Mattamy Rouge Pond

\begin{tabular}{|c|c|c|c|c|c|c|c|c|c|c|c|c|}
\hline Location & 08-Apr & 20-Apr & 05-May & 12-May & 01-Jun & 07-Jun & 15-Jun & 08-Jul & 27-Jul & 19-Aug & 16-Sep & 05-Nov \\
\hline $\mathrm{A}$ & 58 & 76.5 & 94.5 & 83 & 51.5 & 39 & 60 & 28.5 & 44.5 & 31.5 & 39 & 52 \\
\hline $\mathrm{B}$ & 58 & 70.5 & 97.5 & 79.5 & 48.5 & 45 & 59 & 28.5 & 43.4 & 36 & 52 & 53 \\
\hline $\mathrm{C}$ & 58 & 62.5 & 90 & 71.5 & 49.5 & 42 & 60 & 29.5 & 46 & 36 & 58 & 53 \\
\hline Mean & 58 & 69.8 & 94 & 78 & 49.8 & 42 & 59.7 & 28.8 & 44.6 & 34.5 & 49.7 & 52.7 \\
\hline Std. Err. & 0.00 & 2.34 & 1.26 & 1.96 & 0.51 & 1.00 & 0.19 & 0.19 & 0.44 & 0.87 & 3.24 & 0.19 \\
\hline
\end{tabular}




\section{Appendix F: Depth of Water Column and Depth from Surface to Bottom of Sediment Layer}

\section{Depth of Water Column}

Values expressed in metres.

Hydro East Pond

\begin{tabular}{|c|c|c|c|c|c|c|c|c|c|c|c|}
\hline Sample Point & 08-Apr & 20-Apr & 05-May & 12-May & 01-Jun & 07-Jun & 08-Jul & 27-Jul & 19-Aug & 16-Sep & 05-Nov \\
\hline E1 & 1.7 & 1.43 & 1.65 & 1.27 & 1.46 & 1.53 & 1.45 & 1.58 & 1.49 & 1.52 & 1.52 \\
\hline E2 & 1.74 & 1.53 & 1.78 & 1.75 & 1.57 & 1.62 & 1.6 & 1.65 & 1.49 & 1.54 & 1.58 \\
\hline E3 & 0.95 & 1.37 & 1.45 & 1.45 & 1.35 & 1.21 & 1.22 & 1.31 & 1.11 & 1.19 & 1.32 \\
\hline E4 & 1.9 & 1.79 & 1.9 & 1.66 & 1.36 & 1.61 & 1.32 & 1.57 & 1.61 & 1.6 & 1.54 \\
\hline E5 & 1.99 & 2.10 & 1.87 & 1.81 & 1.6 & 1.65 & 1.57 & 1.65 & 1.66 & 1.56 & 1.6 \\
\hline E6 & 1.3 & 1.85 & 1.66 & 1.8 & 1.4 & 1.49 & 1.38 & 1.52 & 1.36 & 1.36 & 1.54 \\
\hline E7 & 2.02 & 1.92 & 1.87 & 1.85 & 1.57 & 1.66 & 1.56 & 1.65 & 1.54 & 1.57 & 1.63 \\
\hline E8 & 2.02 & 1.95 & 1.9 & 1.83 & 1.61 & 1.66 & 1.58 & 1.67 & 1.59 & 1.63 & 1.64 \\
\hline E9 & 1.5 & 1.57 & 1.91 & 1.82 & 1.6 & 1.69 & 1.65 & 1.68 & 1.64 & 1.59 & 1.6 \\
\hline E10 & - & 1.49 & 1.91 & 1.83 & 1.59 & 1.7 & 1.58 & 1.64 & 1.64 & 1.61 & 1.62 \\
\hline E11 & 1.9 & 2.01 & 1.93 & 1.84 & 1.63 & 1.69 & 1.62 & 1.69 & 1.64 & 1.61 & 1.62 \\
\hline E12 & - & 1.30 & 1.55 & 1.69 & 1.35 & 1.57 & 1.29 & 1.58 & 1.51 & 1.45 & 1.4 \\
\hline E13 & - & 1.12 & 1.13 & 1.11 & 0.6 & 0.72 & 0.51 & 0.93 & 1.02 & 0.59 & 0.62 \\
\hline E14 & 1.2 & 1.12 & 1.15 & 1.15 & 0.99 & 0.99 & 0.79 & 1.35 & 0.91 & 0.84 & 0.89 \\
\hline E15 & - & 0.63 & 0.84 & 0.89 & 1.08 & 1.01 & 0.81 & 1.16 & 0.94 & 0.85 & 0.98 \\
\hline E16 & - & 1.22 & 1.19 & 1.13 & 0.88 & 0.99 & 0.74 & 0.99 & 1.03 & 0.82 & 0.98 \\
\hline E17 & 1.54 & 1.48 & 1.38 & 1.34 & 0.96 & 1.14 & 1.09 & 1.17 & 0.94 & 1.02 & 1.1 \\
\hline E18 & - & 1.29 & 1.17 & 1.08 & 0.83 & 0.86 & 0.84 & 0.95 & 0.83 & 0.92 & 0.97 \\
\hline Fixed-Point & 1.24 & 1.35 & 1.45 & 1.49 & 1.7 & 1.61 & 1.69 & 1.6 & 1.68 & 1.7 & - \\
\hline
\end{tabular}


Mattamy Rouge Pond

\begin{tabular}{|c|c|c|c|c|c|c|c|c|c|c|c|}
\hline Sample Point & 08-Apr & 20-Apr & 05-May & 12-May & 31-May & 07-Jun & 08-Jul & 27-Jul & 19-Aug & 16-Sep & 05-Nov \\
\hline M1 & 1.3 & 0.49 & 1.45 & 1.85 & 1.55 & 1.55 & 1.64 & 1.3 & 0.44 & 1.8 & 1.44 \\
\hline M2 & 2.06 & 2.18 & 2.13 & 1.93 & 2.16 & 2.02 & 1.9 & 2.1 & 2.4 & 2.06 & 2.03 \\
\hline M3 & 0.97 & 2.04 & 1.34 & 1.98 & 1.22 & 1.83 & 1.79 & 1.83 & 1.45 & 1.65 & 1.95 \\
\hline M4 & 0.71 & 1.22 & 0.73 & 0.7 & 1.45 & 1.86 & 0.9 & 1.49 & 0.72 & 1.3 & 0.92 \\
\hline M5 & 1.67 & 1.06 & 1.1 & 1.64 & 1.98 & 2 & 1.84 & 1.82 & 1.1 & 1.82 & 1.82 \\
\hline M6 & 0.45 & 1.43 & 2 & 1.95 & 1.69 & 2.05 & 1.85 & 1.85 & 1.55 & 1.85 & 1.94 \\
\hline M7 & 1.81 & 1.95 & 1.83 & 1.82 & 1.81 & 1.85 & 1.82 & 1.71 & 1.66 & 1.76 & 1.59 \\
\hline M8 & 1.99 & 2.06 & 2.12 & 1.57 & 1.69 & 1.72 & 1.67 & 1.45 & 1.32 & 1.72 & 1.6 \\
\hline M9 & 0.66 & 0.61 & 0.69 & 0.6 & 0.5 & 0.57 & 0.48 & 0.45 & 0.58 & 0.57 & 0.48 \\
\hline M10 & 0.45 & 0.51 & 0.35 & 0.5 & 0.36 & 0.48 & 0.39 & 0.52 & 0.42 & 0.42 & 0.37 \\
\hline M11 & 2.28 & 1.75 & 2.18 & 1.95 & 2.05 & 2.16 & 2.1 & 2.12 & 2.12 & 2.03 & 1.93 \\
\hline M12 & 2.24 & 2.23 & 2.25 & 2.24 & 2.15 & 2.14 & 2.07 & 2.6 & 2.5 & 1.98 & 1.94 \\
\hline M13 & 1.71 & 2.08 & 1.76 & 1.46 & 1.63 & 1.73 & 1.51 & 1.68 & 1.75 & 1.64 & 1.69 \\
\hline M14 & 2.47 & 2.08 & 2.36 & 2.03 & 2.01 & 2.07 & 1.93 & 2.26 & 2.46 & 2.02 & 1.82 \\
\hline M15 & 2.09 & 2.33 & 1.97 & 2.04 & 1.95 & 2.11 & 1.89 & 2.1 & 2.9 & 1.8 & 1.87 \\
\hline M16 & 1.95 & 1.93 & 1.78 & 1.77 & 1.62 & 1.63 & 1.85 & 1.77 & 1.78 & 1.81 & 1.47 \\
\hline Fixed-Point & 1.28 & 1.35 & 1.38 & 1.39 & 1.45 & 1.39 & 1.42 & 1.34 & 1.45 & 1.45 & 1.38 \\
\hline
\end{tabular}


Depth from Surface to Bottom of Sediment Layer

All values expressed in metres.

Hydro East Pond

\begin{tabular}{|c|c|c|}
\hline Sample Point & 19-Aug & 05-Nov \\
\hline E1 & 2.06 & 1.91 \\
\hline E2 & 1.66 & 1.83 \\
\hline E3 & 1.40 & 1.68 \\
\hline E4 & 1.87 & 1.97 \\
\hline E5 & 1.82 & 1.87 \\
\hline E6 & 1.83 & 1.85 \\
\hline E7 & 1.79 & 1.84 \\
\hline E8 & 1.82 & 1.89 \\
\hline E9 & 1.91 & 1.91 \\
\hline E10 & 1.87 & 1.88 \\
\hline E11 & 1.84 & 1.91 \\
\hline E12 & 1.89 & 1.60 \\
\hline E13 & 1.26 & 0.76 \\
\hline E14 & 0.94 & 0.94 \\
\hline E15 & 1.02 & 1.17 \\
\hline E16 & 1.45 & 1.42 \\
\hline E17 & 1.41 & 1.52 \\
\hline E18 & 1.19 & 1.24 \\
\hline & & \\
\hline
\end{tabular}

Mattamy Rouge Pond

\begin{tabular}{|c|c|c|c|}
\hline Sample Point & 19-Aug & 16-Sep & 05-Nov \\
\hline M1 & 1.88 & 2.11 & 1.98 \\
\hline M2 & 2.08 & 2.11 & 2.21 \\
\hline M3 & 1.93 & 1.91 & 2.21 \\
\hline M4 & 0.81 & 1.88 & 1.57 \\
\hline M5 & 1.12 & 2.11 & 2.24 \\
\hline M6 & 1.93 & 2.21 & 2.24 \\
\hline M7 & 2.72 & 2.13 & 2.13 \\
\hline M8 & 1.42 & 2.24 & 2.08 \\
\hline M9 & 0.58 & 0.51 & 0.69 \\
\hline M10 & 0.48 & 0.56 & 0.46 \\
\hline M11 & 2.41 & 2.34 & 2.41 \\
\hline M12 & 2.62 & 2.31 & 2.26 \\
\hline M13 & 2.11 & 1.85 & 2.13 \\
\hline M14 & 2.16 & 2.16 & 2.29 \\
\hline M15 & 2.31 & 2.16 & 2.24 \\
\hline M16 & 2.41 & 2.11 & 1.91 \\
\hline
\end{tabular}




\section{Appendix G: Temperature and Dissolved Oxygen (DO) Concentrations}

Temperature and DO profiles on June 15, 2016.

Hydro East Pond

\begin{tabular}{|c|c|c|c|c|c|c|}
\hline \multirow{2}{*}{ Depth } & \multicolumn{2}{|c|}{ Sample Point A } & \multicolumn{2}{c|}{ Sample Point B } & \multicolumn{2}{c|}{ Sample Point C } \\
\cline { 2 - 7 } & $\begin{array}{c}\text { Temperature } \\
\left({ }^{\circ} \mathrm{C}\right)\end{array}$ & $\begin{array}{c}\mathrm{DO} \\
\left(\mathrm{mg} \mathrm{L}^{-1}\right)\end{array}$ & $\begin{array}{c}\text { Temperature } \\
\left({ }^{\circ} \mathrm{C}\right)\end{array}$ & $\begin{array}{c}\mathrm{DO} \\
\left(\mathrm{mg} \mathrm{L}^{-1}\right)\end{array}$ & $\begin{array}{c}\text { Temperature } \\
\left({ }^{\circ} \mathrm{C}\right)\end{array}$ & $\begin{array}{c}\text { DO } \\
\left(\mathrm{mg} \mathrm{L}^{-1}\right)\end{array}$ \\
\hline 20 & 22.04 & 8.68 & 21.51 & 7.66 & 21.33 & 7.79 \\
\hline 40 & 22.04 & 8.6 & 21.73 & 7.7 & 20.43 & 7.41 \\
\hline 60 & 22.06 & 8.53 & 20.47 & 7.42 & 19.55 & 7.37 \\
\hline 80 & 21.79 & 8.47 & 19.37 & 6.92 & 18.98 & 6.92 \\
\hline 100 & 21.15 & 7.64 & 18.79 & 5.84 & 18.41 & 6.46 \\
\hline 120 & 18.69 & 7.56 & 18.24 & 5.54 & 17.72 & 5.12 \\
\hline 140 & 18.45 & 7.25 & 17.76 & 5.22 & 17.36 & 3.98 \\
\hline 160 & 18.15 & 6.56 & 17.29 & 3.26 & 17.03 & 2.23 \\
\hline 180 & 17.58 & 5.02 & 16.99 & 1.47 & 16.87 & 1.71 \\
\hline 200 & 17.4 & 2.72 & - & - & - & - \\
\hline
\end{tabular}

Mattamy Rouge Pond

\begin{tabular}{|c|c|c|c|c|c|c|}
\hline \multirow{2}{*}{ Depth } & \multicolumn{2}{|c|}{ Sample Point A } & \multicolumn{2}{c|}{ Sample Point B } & \multicolumn{2}{c|}{ Sample Point C } \\
\cline { 2 - 7 } & $\begin{array}{c}\text { Temperature } \\
\left({ }^{\circ} \mathrm{C}\right)\end{array}$ & $\begin{array}{c}\mathrm{DO} \\
\left(\mathrm{mg} \mathrm{L}^{-1}\right)\end{array}$ & $\begin{array}{c}\text { Temperature } \\
\left({ }^{\circ} \mathrm{C}\right)\end{array}$ & $\begin{array}{c}\mathrm{DO} \\
\left(\mathrm{mg} \mathrm{L}^{-1}\right)\end{array}$ & $\begin{array}{c}\text { Temperature } \\
\left({ }^{\circ} \mathrm{C}\right)\end{array}$ & $\begin{array}{c}\mathrm{DO} \\
\left(\mathrm{mg} \mathrm{L}^{-1}\right)\end{array}$ \\
\hline 20 & 21.33 & 13.56 & 18.78 & 15.61 & 19.67 & 15 \\
\hline 40 & 20.73 & 13.9 & 18.32 & 14.33 & 19.8 & 15.4 \\
\hline 60 & 19.8 & 13.45 & 17.67 & 11.81 & 19.5 & 15.22 \\
\hline 80 & 18.86 & 13.64 & 17.52 & 9.84 & 18.71 & 15.08 \\
\hline 100 & 18.55 & 13.19 & 17.23 & 6.42 & 18.55 & 14.65 \\
\hline 120 & 18.09 & 12.93 & 17.06 & 3.31 & 18.59 & 13.48 \\
\hline 140 & 17.72 & 12.04 & 17.02 & 3.2 & 17.47 & 10.98 \\
\hline 160 & 16.58 & 4.86 & 16.93 & 1.53 & 17.24 & 7.09 \\
\hline 180 & 16.36 & 2.13 & 16.83 & 0.74 & 17.11 & 5.39 \\
\hline 200 & 16.38 & 1.85 & - & - & 16.95 & 2.36 \\
\hline
\end{tabular}




\section{Appendix H: Volume of Sediment Collected from Sediment Traps}

All values expressed in milliliters.

Hydro East Pond

\begin{tabular}{|c|c|c|c|c|}
\hline Trap Location & July 14 - July 27 & July 27 - Aug. 19 & Aug. 19 - Sept. 16 & Sept. 16 - Nov. 5 \\
\hline A & 125 & 265 & 225 & 580 \\
\hline B & 92 & 305 & 400 & 650 \\
\hline C & 90 & 230 & 325 & 430 \\
\hline
\end{tabular}

Mattamy Rouge Pond

\begin{tabular}{|c|c|c|c|c|}
\hline Trap Location & July 14 - July 27 & July 27 - Aug. 19 & Aug. 19 - Sept. 16 & Sept. 16 - Nov. 5 \\
\hline A & 363.5 & 400 & 450 & 520 \\
\hline B & 190 & 250 & 400 & 500 \\
\hline C & 89 & 230 & 350 & 450 \\
\hline
\end{tabular}




\section{Appendix I: Percent Organic Matter in Bottom Sediment}

\begin{tabular}{|c|c|c|c|c|c|c|c|}
\hline Sample Date \& Location & $\begin{array}{c}\text { Crucible } \\
\text { Weight (g) }\end{array}$ & $\begin{array}{l}\text { Pre-ignition } \\
\text { Weight (g) }\end{array}$ & $\begin{array}{l}\text { Post-ignition } \\
\text { Weight }(\mathrm{g})\end{array}$ & $\begin{array}{c}\text { Post-ignition minus Crucible } \\
\text { Weight }(\mathrm{g})\end{array}$ & $\% \mathrm{OM}$ & $\begin{array}{l}\text { Mean } \\
\% \text { OM }\end{array}$ & $\begin{array}{l}\text { Std. } \\
\text { Err. }\end{array}$ \\
\hline \multirow{3}{*}{ Apr. 8 - HEP } & 18.9915 & 1.0081 & 19.9478 & 0.9563 & 5.14 & \multirow{3}{*}{5.05} & \multirow{3}{*}{0.03} \\
\hline & 17.5979 & 1.001 & 18.5482 & 0.9503 & 5.06 & & \\
\hline & 18.5818 & 1.0013 & 19.5336 & 0.9518 & 4.94 & & \\
\hline \multirow{3}{*}{ Apr. 8 - MAT } & 17.8435 & 1.0031 & 18.7144 & 0.8709 & 13.18 & \multirow{3}{*}{13.96} & \multirow{3}{*}{0.23} \\
\hline & 18.5636 & 1.0037 & 19.4239 & 0.8603 & 14.29 & & \\
\hline & 17.2956 & 1.0058 & 18.1565 & 0.8609 & 14.41 & & \\
\hline \multirow{3}{*}{ May 31 - HEP } & 17.1897 & 1.0041 & 18.1533 & 0.9636 & 4.03 & \multirow{3}{*}{4.06} & \multirow{3}{*}{0.01} \\
\hline & 17.5012 & 1.0019 & 18.4625 & 0.9613 & 4.05 & & \\
\hline & 15.764 & 1.0006 & 16.7236 & 0.9596 & 4.10 & & \\
\hline \multirow{3}{*}{ May 31 - MAT } & 17.9019 & 1.0035 & 18.869 & 0.9671 & 3.63 & \multirow{3}{*}{3.86} & \multirow{3}{*}{0.09} \\
\hline & 19.3541 & 1.0032 & 20.3191 & 0.965 & 3.81 & & \\
\hline & 17.4607 & 1.0014 & 18.4205 & 0.9598 & 4.15 & & \\
\hline \multirow{3}{*}{ July 14 - HEP } & 18.8992 & 0.5336 & 19.3733 & 0.4741 & 11.15 & \multirow{3}{*}{10.80} & \multirow{3}{*}{0.17} \\
\hline & 17.5174 & 0.514 & 17.9789 & 0.4615 & 10.21 & & \\
\hline & 18.492 & 0.5046 & 18.9409 & 0.4489 & 11.04 & & \\
\hline \multirow{3}{*}{ July 14 - MAT } & 17.7656 & 0.4974 & 18.2401 & 0.4745 & 4.60 & \multirow{3}{*}{4.81} & \multirow{3}{*}{0.14} \\
\hline & 18.4752 & 0.4908 & 18.9438 & 0.4686 & 4.52 & & \\
\hline & 17.1119 & 0.5038 & 17.589 & 0.4771 & 5.30 & & \\
\hline \multirow{3}{*}{ Sept. 16 - HEP } & 17.4117 & 0.4995 & 17.8744 & 0.4627 & 7.37 & \multirow{3}{*}{9.30} & \multirow{3}{*}{0.70} \\
\hline & 15.6975 & 0.5055 & 16.1448 & 0.4473 & 11.51 & & \\
\hline & 17.8231 & 0.0587 & 17.8765 & 0.0534 & 9.03 & & \\
\hline \multirow{3}{*}{ Sept. 16 - MAT } & 19.2583 & 0.5034 & 19.7443 & 0.486 & 3.46 & \multirow{3}{*}{3.56} & \multirow{3}{*}{0.06} \\
\hline & 17.3758 & 0.4931 & 17.8504 & 0.4746 & 3.75 & & \\
\hline & 18.0874 & 0.5021 & 18.5721 & 0.4847 & 3.47 & & \\
\hline \multirow{3}{*}{ Nov. 5 - HEP } & 19.3512 & 0.5029 & 19.8128 & 0.4616 & 8.21 & \multirow{3}{*}{8.38} & \multirow{3}{*}{0.05} \\
\hline & 18.5791 & 0.5027 & 19.0392 & 0.4601 & 8.47 & & \\
\hline & 17.4578 & 0.5067 & 17.9216 & 0.4638 & 8.47 & & \\
\hline \multirow{3}{*}{ Nov. 5 - MAT } & 17.8994 & 0.5019 & 18.3692 & 0.4698 & 6.40 & \multirow{3}{*}{6.52} & \multirow{3}{*}{0.06} \\
\hline & 18.1777 & 0.5019 & 18.6458 & 0.4681 & 6.73 & & \\
\hline & 17.5953 & 0.5055 & 18.0683 & 0.473 & 6.43 & & \\
\hline
\end{tabular}




\section{Appendix J: Percent Organic Matter in Sediment Collected from Sediment Traps}

\begin{tabular}{|c|c|c|c|c|c|c|c|}
\hline Sample Date \& Location & $\begin{array}{c}\text { Crucible } \\
\text { Weight (g) }\end{array}$ & $\begin{array}{l}\text { Pre-ignition } \\
\text { Weight }(g)\end{array}$ & $\begin{array}{l}\text { Post-ignition } \\
\text { Weight }(\mathrm{g})\end{array}$ & $\begin{array}{c}\text { Post-ignition minus Crucible } \\
\text { Weight }(\mathrm{g})\end{array}$ & $\% \mathrm{OM}$ & $\begin{array}{l}\text { Mean } \\
\% \mathrm{OM}\end{array}$ & $\begin{array}{l}\text { Std. } \\
\text { Err. }\end{array}$ \\
\hline \multirow{3}{*}{ July 27 - MAT Trap A } & 17.4981 & 0.5022 & 17.9395 & 0.4414 & 12.11 & \multirow{3}{*}{12.34} & \multirow{3}{*}{0.11} \\
\hline & 18.9887 & 0.5097 & 19.4335 & 0.4448 & 12.73 & & \\
\hline & 19.3512 & 0.5001 & 19.7904 & 0.4392 & 12.18 & & \\
\hline \multirow{3}{*}{ July 27 - MAT Trap B } & 17.5951 & 0.4925 & 17.9785 & 0.3834 & 22.15 & \multirow{3}{*}{22.31} & \multirow{3}{*}{0.09} \\
\hline & 17.8993 & 0.4958 & 18.2852 & 0.3859 & 22.17 & & \\
\hline & 17.1871 & 0.5073 & 17.5797 & 0.3926 & 22.61 & & \\
\hline \multirow{2}{*}{ July 27 - MAT Trap C } & 18.5609 & 0.4959 & 18.9504 & 0.3895 & 21.46 & \multirow{2}{*}{21.77} & \multirow{2}{*}{0.23} \\
\hline & 17.8405 & 0.516 & 18.2425 & 0.402 & 22.09 & & \\
\hline \multirow{3}{*}{ July 27 - HPE Trap A } & 18.579 & 0.5014 & 19.0216 & 0.4426 & 11.73 & \multirow{3}{*}{11.92} & \multirow{3}{*}{0.06} \\
\hline & 18.1776 & 0.496 & 18.6137 & 0.4361 & 12.08 & & \\
\hline & 15.7613 & 0.4984 & 16.2001 & 0.4388 & 11.96 & & \\
\hline \multirow{3}{*}{ July 27 - HPE Trap B } & 18.9618 & 0.5162 & 19.4089 & 0.4471 & 13.39 & \multirow{3}{*}{13.53} & \multirow{3}{*}{0.05} \\
\hline & 17.9032 & 0.5081 & 18.3426 & 0.4394 & 13.52 & & \\
\hline & 18.2416 & 0.5091 & 18.6811 & 0.4395 & 13.67 & & \\
\hline \multirow{3}{*}{ July 27 - HPE Trap C } & 16.259 & 0.504 & 16.6894 & 0.4304 & 14.60 & \multirow{3}{*}{14.81} & \multirow{3}{*}{0.09} \\
\hline & 19.2811 & 0.4969 & 19.7048 & 0.4237 & 14.73 & & \\
\hline & 15.9437 & 0.4968 & 16.3655 & 0.4218 & 15.10 & & \\
\hline \multirow{3}{*}{ Aug 19 - MAT Trap A } & 17.8933 & 0.5043 & 18.3113 & 0.418 & 17.11 & \multirow{3}{*}{17.31} & \multirow{3}{*}{0.06} \\
\hline & 16.6368 & 0.5014 & 17.0509 & 0.4141 & 17.41 & & \\
\hline & 17.4579 & 0.5082 & 17.8776 & 0.4197 & 17.41 & & \\
\hline \multirow{3}{*}{ Aug 19 - MAT Trap B } & 18.171 & 0.509 & 18.549 & 0.378 & 25.74 & \multirow{3}{*}{25.54} & \multirow{3}{*}{0.06} \\
\hline & 18.243 & 0.5023 & 18.6176 & 0.3746 & 25.42 & & \\
\hline & 16.1628 & 0.5018 & 16.5369 & 0.3741 & 25.45 & & \\
\hline
\end{tabular}




\begin{tabular}{|c|c|c|c|c|c|c|c|}
\hline Sample Date \& Location & $\begin{array}{c}\text { Crucible } \\
\text { Weight }(\mathrm{g}) \\
\end{array}$ & $\begin{array}{l}\text { Pre-ignition } \\
\text { Weight }(\mathrm{g})\end{array}$ & $\begin{array}{l}\text { Post-ignition } \\
\text { Weight }(\mathrm{g})\end{array}$ & $\begin{array}{c}\text { Post-ignition minus Crucible } \\
\text { Weight }(\mathrm{g})\end{array}$ & $\% \mathrm{OM}$ & $\begin{array}{c}\text { Mean } \\
\% \text { OM }\end{array}$ & $\begin{array}{l}\text { Std. } \\
\text { Err. }\end{array}$ \\
\hline \multirow{3}{*}{ Aug 19 - MAT Trap C } & 18.6416 & 0.5059 & 19.0149 & 0.3733 & 26.21 & \multirow{3}{*}{26.30} & \multirow{3}{*}{0.11} \\
\hline & 18.9142 & 0.501 & 19.2848 & 0.3706 & 26.03 & & \\
\hline & 18.0889 & 0.5005 & 18.4559 & 0.367 & 26.67 & & \\
\hline \multirow{3}{*}{ Aug 19 - HPE Trap A } & 18.3263 & 0.5018 & 18.7543 & 0.428 & 14.71 & \multirow{3}{*}{14.62} & \multirow{3}{*}{0.03} \\
\hline & 16.8597 & 0.4949 & 17.2825 & 0.4228 & 14.57 & & \\
\hline & 18.8593 & 0.5051 & 19.2908 & 0.4315 & 14.57 & & \\
\hline \multirow{3}{*}{ Aug 19 - HPE Trap B } & 19.444 & 0.5191 & 19.8816 & 0.4376 & 15.70 & \multirow{3}{*}{15.43} & \multirow{3}{*}{0.10} \\
\hline & 20.6796 & 0.5023 & 21.1042 & 0.4246 & 15.47 & & \\
\hline & 24.0587 & 0.5037 & 24.4862 & 0.4275 & 15.13 & & \\
\hline \multirow{3}{*}{ Aug 19 - HPE Trap C } & 27.6154 & 0.4998 & 28.0605 & 0.4451 & 10.94 & \multirow{3}{*}{10.80} & \multirow{3}{*}{0.05} \\
\hline & 20.7001 & 0.499 & 21.146 & 0.4459 & 10.64 & & \\
\hline & 18.0845 & 0.51 & 18.5393 & 0.4548 & 10.82 & & \\
\hline \multirow{3}{*}{ Sept. 16 - MAT Trap A } & 17.4981 & 0.5025 & 17.8953 & 0.3972 & 20.96 & \multirow{3}{*}{21.20} & \multirow{3}{*}{0.08} \\
\hline & 18.9887 & 0.5054 & 19.3868 & 0.3981 & 21.23 & & \\
\hline & 19.3512 & 0.4915 & 19.7374 & 0.3862 & 21.42 & & \\
\hline \multirow{3}{*}{ Sept. 16 - MAT Trap B } & 17.5951 & 0.5044 & 17.9922 & 0.3971 & 21.27 & \multirow{3}{*}{21.48} & \multirow{3}{*}{0.08} \\
\hline & 17.8993 & 0.5003 & 18.2908 & 0.3915 & 21.75 & & \\
\hline & 17.1871 & 0.5026 & 17.582 & 0.3949 & 21.43 & & \\
\hline \multirow{3}{*}{ Sept. 16 - MAT Trap C } & 18.5609 & 0.5054 & 18.9532 & 0.3923 & 22.38 & \multirow{3}{*}{22.57} & \multirow{3}{*}{0.08} \\
\hline & 17.8405 & 0.5 & 18.228 & 0.3875 & 22.50 & & \\
\hline & 17.8933 & 0.503 & 18.2815 & 0.3882 & 22.82 & & \\
\hline \multirow{3}{*}{ Sept. 16 - HPE Trap A } & 18.579 & 0.5032 & 19.0141 & 0.4351 & 13.53 & \multirow{3}{*}{13.57} & \multirow{3}{*}{0.02} \\
\hline & 18.1776 & 0.5088 & 18.6171 & 0.4395 & 13.62 & & \\
\hline & 15.7613 & 0.5106 & 16.2027 & 0.4414 & 13.55 & & \\
\hline
\end{tabular}




\begin{tabular}{|c|c|c|c|c|c|c|c|}
\hline Sample Date \& Location & $\begin{array}{c}\text { Crucible } \\
\text { Weight }(\mathrm{g})\end{array}$ & $\begin{array}{c}\text { Pre-ignition } \\
\text { Weight }(\mathrm{g})\end{array}$ & $\begin{array}{c}\text { Post-ignition } \\
\text { Weight (g) }\end{array}$ & $\begin{array}{c}\text { Post-ignition minus Crucible } \\
\text { Weight }(\mathrm{g})\end{array}$ & $\% \mathrm{OM}$ & $\begin{array}{l}\text { Mean } \\
\% \text { OM }\end{array}$ & $\begin{array}{l}\text { Std. } \\
\text { Err. }\end{array}$ \\
\hline \multirow{3}{*}{ Sept. 16 - HPE Trap B } & 18.9618 & 0.5115 & 19.4027 & 0.4409 & 13.80 & \multirow{3}{*}{13.92} & \multirow{3}{*}{0.04} \\
\hline & 17.9032 & 0.5061 & 18.339 & 0.4358 & 13.89 & & \\
\hline & 18.2416 & 0.5015 & 18.6726 & 0.431 & 14.06 & & \\
\hline \multirow{3}{*}{ Sept. 16 - HPE Trap C } & 16.259 & 0.5041 & 16.6922 & 0.4332 & 14.06 & \multirow{3}{*}{14.03} & \multirow{3}{*}{0.02} \\
\hline & 19.2811 & 0.5105 & 19.7197 & 0.4386 & 14.08 & & \\
\hline & 15.9437 & 0.5048 & 16.3781 & 0.4344 & 13.95 & & \\
\hline \multirow{3}{*}{ Nov. 5 - MAT Trap A } & 8.6175 & 0.4999 & 9.0129 & 0.3954 & 20.90 & \multirow{3}{*}{20.80} & \multirow{3}{*}{0.04} \\
\hline & 16.6369 & 0.5049 & 17.0366 & 0.3997 & 20.84 & & \\
\hline & 17.4584 & 0.5074 & 17.861 & 0.4026 & 20.65 & & \\
\hline \multirow{3}{*}{ Nov. 5 - MAT Trap B } & 18.1706 & 0.5038 & 18.5632 & 0.3926 & 22.07 & \multirow{3}{*}{21.91} & \multirow{3}{*}{0.22} \\
\hline & 18.2432 & 0.5056 & 18.6417 & 0.3985 & 21.18 & & \\
\hline & 16.1632 & 0.4986 & 16.5498 & 0.3866 & 22.46 & & \\
\hline \multirow{2}{*}{ Nov. 5 - MAT Trap C } & 18.6421 & 0.5028 & 19.0223 & 0.3802 & 24.38 & \multirow{2}{*}{24.43} & \multirow{2}{*}{0.04} \\
\hline & 18.9146 & 0.4946 & 19.2881 & 0.3735 & 24.48 & & \\
\hline \multirow{2}{*}{ Nov. 5 - HPE Trap A } & 18.089 & 0.5057 & 18.5288 & 0.4398 & 13.03 & \multirow{2}{*}{13.03} & \multirow{2}{*}{0.00} \\
\hline & 18.3275 & 0.5002 & 18.7625 & 0.435 & 13.03 & & \\
\hline \multirow{2}{*}{ Nov. 5 - HPE Trap B } & 16.8598 & 0.5018 & 17.2913 & 0.4315 & 14.01 & \multirow{2}{*}{14.17} & \multirow{2}{*}{0.11} \\
\hline & 18.86 & 0.5039 & 19.2917 & 0.4317 & 14.33 & & \\
\hline \multirow{2}{*}{ Nov. 5 - HPE Trap C } & 19.4448 & 0.5059 & 19.8747 & 0.4299 & 15.02 & \multirow{2}{*}{15.00} & \multirow{2}{*}{0.01} \\
\hline & 18.0864 & 0.5005 & 18.5119 & 0.4255 & 14.99 & & \\
\hline
\end{tabular}




\section{Appendix K: Concentrations of TSS in Water Samples}

All values expressed in $\mathrm{mg} \mathrm{L}^{-1}$.

Hydro East Pond

\begin{tabular}{|c|c|c|c|c|c|c|c|c|c|c|c|c|}
\hline & 08-Apr & 20-Apr & 05-May & 12-May & 31-May & 07-Jun & 08-Jul & 27-Jul & 19-Aug & 16-Sep & 05-Nov & 12-Dec \\
\hline Inlet & 20 & 100 & 100 & 50 & 50 & 100 & 150 & 150 & 167 & 50 & 50 & 50 \\
\hline Outlet & 50 & 50 & 50 & 25 & 50 & 50 & 100 & 100 & 233 & 50 & 50 & 50 \\
\hline
\end{tabular}

Mattamy Rouge Pond

\begin{tabular}{|c|c|c|c|c|c|c|c|c|c|c|c|c|}
\hline & 08-Apr & 20-Apr & 05-May & 12-May & 31-May & 07-Jun & 08-Jul & 27-Jul & 19-Aug & 16-Sep & 05-Nov & 12-Dec \\
\hline Inlet & 33.3 & 80 & 66.7 & 50 & 150 & 100 & 150 & 150 & 167 & 50 & 75 & 50 \\
\hline Outlet & 80 & 66.7 & 66.7 & 33 & 100 & 66.7 & 150 & 100 & 233 & 50 & 50 & 50 \\
\hline
\end{tabular}




\section{Appendix L: Mean Concentrations of TP in Water Samples}

All values expressed in $\mu \mathrm{mol} \mathrm{L} \mathrm{L}^{-1}$.

Hydro East Pond

\begin{tabular}{|c|c|c|c|c|c|c|c|c|c|c|c|c|c|}
\hline & 08-Apr & 20-Apr & 05-May & 12-May & 31-May & 01-Jun & 07-Jun & 08-Jul & 27-Jul & 19-Aug & 16-Sep & $05-\mathrm{Nov}$ & 12-Dec \\
\hline Inlet & 4.68 & 0.16 & 1.63 & 0.40 & 1.64 & 1.62 & 3.31 & 2.46 & 6.16 & 1.84 & 1.33 & 0.31 & 0.60 \\
\hline Std. Err. & 0.33 & 0.05 & 0.43 & 0.17 & 0.01 & 0.21 & 0.10 & 0.06 & 0.66 & 0.14 & 0.23 & 0.01 & 0.06 \\
\hline Outlet & 2.36 & 1.04 & 0.45 & 1.60 & 1.22 & 1.39 & 4.44 & 4.93 & 4.82 & 2.17 & 1.26 & 0.53 & 1.17 \\
\hline Std. Err. & 0.27 & 0.17 & 0.08 & 0.41 & 0.32 & 0.02 & 0.04 & 0.32 & 0.54 & 0.33 & 0.11 & 0.00 & 0.08 \\
\hline Composite & 3.44 & 4.30 & 2.81 & 7.17 & 1.95 & 2.87 & 5.61 & 7.49 & 3.72 & 4.54 & 1.55 & 0.58 & 0.51 \\
\hline Std. Err. & 0.63 & 0.50 & 0.30 & 0.66 & 0.24 & 0.02 & 0.00 & 0.29 & 0.07 & 0.33 & 0.11 & 0.01 & 0.03 \\
\hline
\end{tabular}

Mattamy Rouge Pond

\begin{tabular}{|c|c|c|c|c|c|c|c|c|c|c|c|c|c|}
\hline & 08-Apr & 20-Apr & 05-May & 12-May & 31-May & 01-Jun & 07-Jun & 08-Jul & 27-Jul & 19-Aug & 16-Sep & 05-Nov & 12-Dec \\
\hline Inlet & 3.66 & 0.56 & 3.70 & 1.02 & 3.36 & 3.75 & 5.79 & 7.83 & 6.87 & 5.23 & 0.60 & 0.63 & 1.30 \\
\hline Std. Err. & 0.39 & 0.09 & 0.63 & 0.10 & 0.12 & 0.02 & 0.38 & 0.15 & 0.66 & 0.14 & 0.23 & 0.01 & 0.06 \\
\hline Outlet & 4.50 & 0.36 & 1.56 & 3.23 & 2.96 & 3.92 & 8.78 & 8.39 & 6.80 & 4.29 & 1.28 & 0.74 & 1.39 \\
\hline Std. Err. & 0.25 & 0.17 & 0.19 & 0.42 & 0.14 & 0.27 & 0.39 & 0.12 & 0.54 & 0.33 & 0.11 & 0.00 & 0.08 \\
\hline Composite & 2.80 & 1.37 & 3.43 & 4.52 & 3.00 & 3.94 & 9.88 & 7.96 & 9.15 & 3.08 & 1.62 & 1.07 & 1.48 \\
\hline Std. Err. & 0.23 & 0.26 & 0.38 & 0.52 & 0.14 & 0.06 & 0.06 & 0.04 & 0.07 & 0.33 & 0.11 & 0.01 & 0.03 \\
\hline
\end{tabular}




\section{Appendix M: Mean Concentrations of DRP in Water Samples}

All values expressed in $\mu \mathrm{mol} \mathrm{L} \mathrm{L}^{-1}$.

Hydro East Pond

\begin{tabular}{|c|c|c|c|c|c|c|c|c|c|c|c|c|c|}
\hline & 08-Apr & 20-Apr & 05-May & 12-May & 31-May & 01-Jun & 07-Jun & 08-Jul & 27-Jul & 19-Aug & 16-Sep & 05-Nov & 12-Dec \\
\hline Inlet & 0.88 & 0.55 & 0.74 & 0.76 & 0.86 & 1.01 & 0.87 & 3.01 & 2.79 & 2.13 & 0.76 & 0.21 & 0.18 \\
\hline Std. Err. & - & - & - & - & - & - & - & 0.07 & 0.05 & 0.05 & 0.02 & 0.01 & 0.05 \\
\hline Outlet & 0.57 & 0.56 & 0.69 & 0.57 & 0.65 & 0.49 & 0.68 & 1.01 & 1.15 & 2.42 & 0.63 & 0.42 & 0.44 \\
\hline Std. Err. & - & - & - & - & - & - & - & 0.07 & 0.13 & 0.05 & 0.07 & 0.04 & 0.16 \\
\hline Composite & 0.55 & 1.42 & 0.76 & 0.76 & 1.34 & 1.38 & 0.65 & 1.68 & 2.43 & 2.01 & 0.70 & 1.23 & 0.38 \\
\hline Std. Err. & 0.10 & 0.52 & 0.16 & 0.04 & 0.23 & 0.27 & 0.02 & 0.14 & 0.34 & 0.15 & 0.04 & 0.00 & 0.13 \\
\hline
\end{tabular}

Mattamy Rouge Pond

\begin{tabular}{|c|c|c|c|c|c|c|c|c|c|c|c|c|c|}
\hline & 08-Apr & 20-Apr & 05-May & 12-May & 31-May & 01-Jun & 07-Jun & 08-Jul & 27-Jul & 19-Aug & 16-Sep & 05-Nov & 12-Dec \\
\hline Inlet & 0.43 & 0.68 & 0.46 & 0.39 & 0.69 & 0.54 & 0.91 & 4.17 & 1.44 & 1.59 & 0.46 & 1.26 & 0.84 \\
\hline Std. Err. & - & - & - & - & - & - & - & 0.12 & 0.32 & 0.10 & 0.07 & 0.00 & 0.04 \\
\hline Outlet & 0.41 & 0.72 & 0.43 & 0.53 & 0.54 & 0.86 & 0.66 & 0.69 & 0.41 & 0.66 & 0.76 & 1.27 & 0.30 \\
\hline Std. Err. & - & - & - & - & - & - & - & 0.13 & 0.09 & 0.10 & 0.01 & 0.12 & 0.07 \\
\hline Composite & 2.59 & 0.95 & 1.32 & 0.22 & 1.82 & 1.16 & 0.71 & 0.94 & 4.08 & 3.40 & 0.45 & 0.88 & 0.25 \\
\hline Std. Err. & 0.08 & 0.13 & 0.33 & 0.03 & 0.23 & 0.19 & 0.06 & 0.02 & 0.35 & 0.18 & 0.10 & 0.10 & 0.00 \\
\hline
\end{tabular}




\section{Appendix N: Mean Concentrations of Ammonium in Water Samples}

All values expressed in $\mu \mathrm{mol} \mathrm{L} \mathrm{L}^{-1}$.

Hydro East Pond

\begin{tabular}{|c|c|c|c|c|c|c|c|c|c|c|c|c|c|}
\hline & 08-Apr & 20-Apr & 05-May & 12-May & 31-May & 01-Jun & 07-Jun & 08-Jul & 27-Jul & 19-Aug & 16-Sep & $05-\mathrm{Nov}$ & 12-Dec \\
\hline Inlet & 6.32 & 2.38 & 3.20 & 11.94 & 6.50 & 14.79 & 13.38 & 4.23 & 2.35 & 3.28 & 5.01 & 4.10 & 9.23 \\
\hline Std. Err. & - & - & - & - & 1.43 & - & - & 0.05 & 0.04 & 0.01 & 0.37 & 0.30 & 1.32 \\
\hline Outlet & 4.27 & 2.95 & 8.25 & 17.24 & 4.87 & 9.27 & 12.80 & 3.20 & 2.48 & 2.98 & 2.58 & 11.71 & 3.07 \\
\hline Std. Err. & - & - & - & - & 0.37 & - & - & 1.09 & 0.03 & 0.09 & 0.11 & 3.25 & 0.19 \\
\hline Composite & 2.77 & 0.80 & 4.68 & 11.51 & 6.84 & 8.40 & 16.72 & 1.66 & 2.26 & 4.66 & 10.41 & 9.78 & 5.93 \\
\hline Std. Err. & 1.09 & 0.13 & 1.47 & 0.20 & 0.41 & 0.14 & 1.56 & 0.11 & 0.14 & 0.01 & 0.08 & 2.50 & 0.31 \\
\hline
\end{tabular}

Mattamy Rouge Pond

\begin{tabular}{|c|c|c|c|c|c|c|c|c|c|c|c|c|c|}
\hline & 08-Apr & 20-Apr & 05-May & 12-May & 31-May & 01-Jun & 07-Jun & 08-Jul & 27-Jul & 19-Aug & 16-Sep & $05-\mathrm{Nov}$ & 12-Dec \\
\hline Inlet & 2.64 & 4.51 & 9.93 & 6.64 & 5.62 & 4.60 & 4.92 & 6.96 & 2.65 & 1.72 & 9.83 & 7.87 & 5.14 \\
\hline Std. Err. & - & - & - & - & 0.56 & - & - & 0.32 & 0.07 & 0.12 & 0.35 & 0.16 & 0.24 \\
\hline Outlet & 3.95 & 3.70 & 6.74 & 15.38 & 3.73 & 7.75 & 5.70 & 1.13 & 2.64 & 4.50 & 8.95 & 5.15 & 3.49 \\
\hline Std. Err. & - & - & - & - & 0.21 & - & - & 0.04 & 0.12 & 0.02 & 0.06 & 0.27 & 1.25 \\
\hline Composite & 1.19 & 1.36 & 2.20 & 9.33 & 3.35 & 2.54 & 1.47 & 1.60 & 1.75 & 3.46 & 11.87 & 5.80 & 2.17 \\
\hline Std. Err. & 0.01 & 0.04 & 0.21 & 0.44 & 0.42 & 0.06 & 0.04 & 0.08 & 0.10 & 0.02 & 0.13 & 0.39 & 0.12 \\
\hline
\end{tabular}




\section{Appendix O: Mean Concentrations of Nitrate in Water Samples}

All values expressed in $\mu \mathrm{mol} \mathrm{L} \mathrm{L}^{-1}$.

Hydro East Pond

\begin{tabular}{|c|c|c|c|c|c|c|c|c|c|c|c|c|c|}
\hline & 08-Apr & 20-Apr & 05-May & 12-May & 31-May & 01-Jun & 07-Jun & 08-Jul & 27-Jul & 19-Aug & 16-Sep & 05-Nov & 12-Dec \\
\hline Inlet & 206.76 & 98.31 & 111.64 & 38.68 & 39.55 & 81.19 & 82.46 & 95.15 & 69.02 & 97.35 & 79.19 & 147.73 & 196.03 \\
\hline Std. Err. & 2.39 & 8.36 & 2.60 & 2.73 & 3.10 & 1.19 & 5.42 & 0.96 & 2.14 & 0.52 & 4.84 & 3.66 & 10.41 \\
\hline Outlet & 171.96 & 58.11 & 110.70 & 52.56 & 37.81 & 64.06 & 78.25 & 81.48 & 43.56 & 25.50 & 28.76 & 106.03 & 124.38 \\
\hline Std. Err. & 3.11 & 3.82 & 6.46 & 0.10 & 3.76 & 1.40 & 1.30 & 6.73 & 1.81 & 0.44 & 1.77 & 3.26 & 5.80 \\
\hline Composite & 209.46 & 140.88 & 251.09 & 66.94 & 36.58 & 79.35 & 54.14 & 71.96 & 51.19 & 35.10 & 33.31 & 131.92 & 136.64 \\
\hline Std. Err. & 5.26 & 2.63 & 7.29 & 13.33 & 1.29 & 2.67 & 1.62 & 1.15 & 5.17 & 3.43 & 1.72 & 2.75 & 0.90 \\
\hline
\end{tabular}

Mattamy Rouge Pond

\begin{tabular}{|c|c|c|c|c|c|c|c|c|c|c|c|c|c|}
\hline & 08-Apr & 20-Apr & 05-May & 12-May & 31-May & 01-Jun & 07-Jun & 08-Jul & 27-Jul & 19-Aug & 16-Sep & $05-\mathrm{Nov}$ & 12-Dec \\
\hline Inlet & 77.11 & 26.62 & 178.44 & 17.98 & 12.44 & 18.06 & 15.98 & 58.65 & 17.27 & 17.67 & 20.41 & 54.26 & 45.20 \\
\hline Std. Err. & 0.34 & 0.48 & 6.08 & 1.53 & 0.02 & 1.81 & 2.22 & 0.87 & 2.22 & 0.29 & 4.51 & 1.47 & 0.72 \\
\hline Outlet & 52.09 & 19.53 & 257.34 & 33.29 & 13.19 & 19.04 & 13.46 & 31.00 & 12.98 & 14.98 & 17.12 & 56.82 & 39.05 \\
\hline Std. Err. & 2.49 & 0.24 & 6.30 & 0.80 & 0.29 & 0.62 & 0.71 & 0.12 & 0.60 & 0.37 & 1.12 & 1.93 & 1.21 \\
\hline Composite & 67.64 & 20.07 & 197.50 & 25.92 & 18.72 & 10.27 & 26.93 & 14.65 & 17.79 & 19.04 & 18.85 & 50.36 & 40.18 \\
\hline Std. Err. & 5.97 & 3.30 & 1.77 & 2.56 & 3.47 & 0.31 & 0.95 & 0.13 & 3.36 & 1.62 & 1.16 & 0.04 & 1.52 \\
\hline
\end{tabular}




\section{Appendix P: Mean Concentrations of TIN in Water Samples}

$\mathrm{TIN}=\mathrm{NH}_{4}^{+}+\mathrm{NO}_{3}$

All values expressed in $\mu \mathrm{mol} \mathrm{L} \mathrm{L}^{-1}$.

Hydro East Pond

\begin{tabular}{|c|c|c|c|c|c|c|c|c|c|c|c|c|c|}
\hline & 08-Apr & 20-Apr & 05-May & 12-May & 31-May & 01-Jun & 07-Jun & 08-Jul & 27-Jul & 19-Aug & 16-Sep & $05-\mathrm{Nov}$ & 12-Dec \\
\hline Inlet & 213.07 & 100.70 & 114.84 & 50.62 & 46.05 & 95.97 & 95.84 & 99.38 & 71.37 & 100.63 & 84.21 & 151.83 & 205.26 \\
\hline Outlet & 176.23 & 61.06 & 118.95 & 69.80 & 42.68 & 73.33 & 91.05 & 84.68 & 46.04 & 28.48 & 31.34 & 117.74 & 127.45 \\
\hline Composite & 212.22 & 141.68 & 255.77 & 78.45 & 43.41 & 87.76 & 70.86 & 73.62 & 53.44 & 39.76 & 43.72 & 141.71 & 142.56 \\
\hline
\end{tabular}

Mattamy Rouge Pond

\begin{tabular}{|c|c|c|c|c|c|c|c|c|c|c|c|c|c|}
\hline \multirow{2}{*}{ 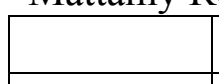 } & \multirow{2}{*}{\multicolumn{2}{|c|}{$08 \Delta \mathrm{nr}$}} & \multirow[b]{2}{*}{ 05-May } & \multirow[b]{2}{*}{ 12-May } & \multirow[b]{2}{*}{ 31-May } & \multirow{2}{*}{ 01-Jun } & \multirow{2}{*}{ 07-Jun } & \multirow[b]{2}{*}{ 08-Jul } & \multirow[b]{2}{*}{ 27-Jul } & \multirow[b]{2}{*}{ 19-Aug } & \multirow[b]{2}{*}{ 16-Sen } & \multirow[b]{2}{*}{$05-\mathrm{Nov}$} & \multirow[b]{2}{*}{ 12-Dec } \\
\hline & & & & & & & & & & & & & \\
\hline Inlet & 79.75 & 31.13 & 188.37 & 24.62 & 18.06 & 22.67 & 20.90 & 65.61 & 19.93 & 19.39 & 30.24 & 62.12 & 50.34 \\
\hline Outlet & 56.04 & 23.23 & 264.08 & 48.67 & 16.92 & 26.80 & 19.16 & 32.13 & 15.62 & 19.48 & 26.07 & 61.97 & 42.54 \\
\hline Composite & 68.83 & 21.43 & 199.70 & 35.25 & 22.07 & 12.81 & 28.40 & 16.25 & 19.54 & 22.50 & 30.72 & 56.16 & 42.35 \\
\hline
\end{tabular}




\section{Appendix Q: Retention of TSS and Nutrient Constituents in HEP and MAT}

\section{Percent Retention Approach}

All values expressed as percentages.

Hydro East Pond

\begin{tabular}{|c|c|c|c|c|c|c|c|c|c|c|c|c|c|}
\hline & 08-Apr & 20-Apr & 05-May & 12-May & 31-May & 01-Jun & 07-Jun & 08-Jul & 27-Jul & 19-Aug & 16-Sep & 05-Nov & 12-Dec \\
\hline TSS & -150 & 50 & 50 & 50 & 0 & - & 50 & 33.33 & 33.33 & -39.52 & 0 & 0 & 0 \\
\hline TP & 49.61 & -551.61 & 72.32 & -295.52 & 25.51 & 14.24 & -34.19 & -100.46 & 21.66 & -17.63 & 5.61 & -74.47 & -94.05 \\
\hline $\mathrm{NH}_{4}^{+}$ & 32.39 & -23.88 & -157.50 & -44.47 & 25.13 & 37.33 & 4.32 & 24.39 & -5.35 & 9.16 & 48.61 & -185.53 & 66.73 \\
\hline $\mathrm{NO}_{3}$ & 16.83 & 40.89 & 0.84 & -35.88 & 4.39 & 21.09 & 5.10 & 14.36 & 36.88 & 73.81 & 63.68 & 28.23 & 36.55 \\
\hline TIN & 17.29 & 39.36 & -3.58 & -37.90 & 7.31 & 23.60 & 4.99 & 14.79 & 35.49 & 71.70 & 62.78 & 22.45 & 37.91 \\
\hline
\end{tabular}

Mattamy Rouge Pond

\begin{tabular}{|c|c|c|c|c|c|c|c|c|c|c|c|c|c|}
\hline & 08-Apr & 20-Apr & 05-May & 12-May & 31-May & 01-Jun & 07-Jun & 08-Jul & 27-Jul & 19-Aug & 16-Sep & 05-Nov & 12-Dec \\
\hline TSS & -140.24 & 16.63 & 0 & 34 & 33.33 & - & 33.30 & 0 & 33.33 & -39.52 & 0 & 33.33 & 0 \\
\hline TP & -23.02 & 35.19 & 57.82 & -217.16 & 12.00 & -4.48 & -51.71 & -7.23 & 0.97 & 18.00 & -115.30 & -18.04 & -7.00 \\
\hline DRP & 4.65 & -5.88 & 6.52 & -35.90 & 21.74 & -57.41 & 26.67 & 83.51 & 71.31 & 58.61 & -66.07 & -0.76 & 63.88 \\
\hline $\mathrm{NH}_{4}^{+}$ & -49.33 & 17.87 & 32.12 & -131.77 & 33.70 & -68.41 & -15.91 & 83.71 & 0.66 & -161.89 & 8.91 & 34.49 & 32.04 \\
\hline $\mathrm{NO}_{3}$ & 32.44 & 26.65 & -44.22 & -85.09 & -6.03 & -5.42 & 15.78 & 47.14 & 24.85 & 15.21 & 16.14 & -4.72 & 13.61 \\
\hline TIN & 29.73 & 25.38 & -40.20 & -97.67 & 6.34 & -18.21 & 8.32 & 51.02 & 21.63 & -0.49 & 13.79 & 0.25 & 15.49 \\
\hline
\end{tabular}




\section{In - Out Approach}

All values expressed in $\mu \mathrm{mol} \mathrm{L} \mathrm{L}^{-1}$, except for TSS which are expressed as $\mathrm{mg} \mathrm{L}^{-1}$.

Hydro East Pond

\begin{tabular}{|c|c|c|c|c|c|c|c|c|c|c|c|c|c|}
\hline & 08-Apr & 20-Apr & 05-May & 12-May & 31-May & 01-Jun & 07-Jun & 08-Jul & 27-Jul & 19-Aug & 16-Sep & $05-\mathrm{Nov}$ & $12-\mathrm{Dec}$ \\
\hline TSS & -30 & 50 & 50 & 25 & 0 & - & 50 & 50 & 50 & -66 & 0 & 0 & 0 \\
\hline $\mathrm{TP}$ & 2.32 & -0.88 & 1.18 & -1.19 & 0.42 & 0.23 & -1.13 & -2.47 & 1.33 & -0.33 & 0.07 & -0.23 & -0.57 \\
\hline DRP & 0.30 & -0.01 & 0.05 & 0.19 & 0.20 & 0.51 & 0.18 & 2.01 & 1.64 & -0.29 & 0.13 & -0.21 & -0.26 \\
\hline $\mathrm{NH}_{4}^{+}$ & 2.05 & -0.57 & -5.04 & -5.31 & 1.63 & 5.52 & 0.58 & 1.03 & -0.13 & 0.30 & 2.44 & -7.61 & 6.16 \\
\hline $\mathrm{NO}_{3}$ & 34.80 & 40.20 & 0.94 & -13.88 & 1.73 & 17.13 & 4.21 & 13.67 & 25.46 & 71.85 & 50.43 & 41.70 & 71.65 \\
\hline TIN & 36.84 & 39.63 & -4.11 & -19.19 & 3.37 & 22.65 & 4.79 & 14.70 & 25.33 & 72.15 & 52.86 & 34.09 & 77.81 \\
\hline
\end{tabular}

Mattamy Rouge Pond

\begin{tabular}{|c|c|c|c|c|c|c|c|c|c|c|c|c|c|}
\hline & 08-Apr & 20-Apr & 05-May & 12-May & 31-May & 01-Jun & 07-Jun & 08-Jul & 27-Jul & 19-Aug & 16-Sep & $05-\mathrm{Nov}$ & 12-Dec \\
\hline TSS & -46.7 & 13.3 & 0 & 17 & 50 & - & 33.3 & 0 & 50 & -66 & 0 & 25 & 0 \\
\hline $\mathrm{TP}$ & -0.84 & 0.20 & 2.14 & -2.21 & 0.40 & -0.17 & -2.99 & -0.57 & 0.07 & 0.94 & -0.69 & -0.11 & -0.09 \\
\hline DRP & 0.02 & -0.04 & 0.03 & -0.14 & 0.15 & -0.31 & 0.24 & 3.48 & 1.03 & 0.93 & -0.30 & -0.01 & 0.53 \\
\hline $\mathrm{NH}_{4}^{+}$ & -1.30 & 0.81 & 3.19 & -8.75 & 1.90 & -3.15 & -0.78 & 5.83 & 0.02 & -2.78 & 0.88 & 2.71 & 1.65 \\
\hline $\mathrm{NO}_{3}$ & 25.01 & 7.09 & -78.91 & -15.30 & -0.75 & -0.98 & 2.52 & 27.65 & 4.29 & 2.69 & 3.29 & -2.56 & 6.15 \\
\hline TIN & 23.71 & 7.90 & -75.72 & -24.05 & 1.15 & -4.13 & 1.74 & 33.47 & 4.31 & -0.10 & 4.17 & 0.15 & 7.80 \\
\hline
\end{tabular}




\section{Appendix R: Mean Concentrations of TP from Bottom Sediment and Sediment Collected from Sediment Traps}

\section{Bottom Sediment}

Hydro East Pond

\begin{tabular}{|l|c|c|c|c|c|}
\hline & 08-Apr & 31-May & 14-Jul & 16-Sep & $05-$ Nov \\
\hline Concentration $\left(\mathrm{mg} \mathrm{P} \mathrm{kg}^{-1}\right)$ & 884.36 & 780.44 & 1100.56 & 1026.93 & 974.70 \\
\hline Std. Err. & 36.20 & 4.42 & 4.23 & 9.81 & 5.57 \\
\hline Concentration $\left(\mathrm{mol} \mathrm{L}^{-1}\right)$ & 0.037 & 0.033 & 0.046 & 0.043 & 0.041 \\
\hline Std. Err. & 0.0015 & 0.0002 & 0.0002 & 0.0004 & 0.0002 \\
\hline
\end{tabular}

Mattamy Rouge Pond

\begin{tabular}{|l|c|c|c|c|c|}
\hline & 08-Apr & 31-May & 14-Jul & 16-Sep & $05-$ Nov \\
\hline Concentration $\left(\mathrm{mg} \mathrm{P} \mathrm{kg}^{-1}\right)$ & 1154.89 & 669.44 & 817.34 & 659.32 & 794.48 \\
\hline Std. Err. & 24.63 & 7.10 & 12.00 & 6.69 & 3.89 \\
\hline Concentration $\left(\mathrm{mol} \mathrm{L}^{-1}\right)$ & 0.048 & 0.028 & 0.034 & 0.028 & 0.033 \\
\hline Std. Err. & 0.0010 & 0.0003 & 0.0005 & 0.0003 & 0.0002 \\
\hline
\end{tabular}

\section{Sediment Collected from Sediment Traps}

All values expressed in $\mathrm{mg} \mathrm{P} \mathrm{kg}^{-1}$ sediment.

Hydro East Pond

\begin{tabular}{|c|l|c|c|c|c|}
\hline Trap Location & & 27-Jul & 19-Aug & 16-Sep & 05-Nov \\
\hline \multirow{2}{*}{ A } & Concentration & 1343.66 & 1489.51 & 4112.62 & 3253.72 \\
\cline { 2 - 6 } & Std. Err. & 59.97 & 7.36 & 81.15 & 242.71 \\
\hline \multirow{2}{*}{ B } & Concentration & 2301.44 & 2671.88 & 2562.03 & 2397.98 \\
\cline { 2 - 6 } & Std. Err. & 17.21 & 83.57 & 64.86 & 53.69 \\
\hline \multirow{2}{*}{ C } & Concentration & 3935.36 & 5804.56 & 4118.39 & 3838.18 \\
\cline { 2 - 6 } & Std. Err. & 101.56 & 104.79 & 40.72 & 92.28 \\
\hline
\end{tabular}

Mattamy Rouge Pond

\begin{tabular}{|c|l|c|c|c|c|}
\hline Trap Location & & 27-Jul & $19-A u g$ & $16-\mathrm{Sep}$ & 05-Nov \\
\hline \multirow{2}{*}{ A } & Concentration & 973.86 & 1305.91 & 3155.12 & 3017.51 \\
\cline { 2 - 6 } & Std. Err. & 9.36 & 76.15 & 33.56 & 40.41 \\
\hline \multirow{2}{*}{ B } & Concentration & 1536.30 & 1663.60 & 3696.61 & 3604.87 \\
\cline { 2 - 6 } & Std. Err. & 10.66 & 22.57 & 81.81 & 50.24 \\
\hline \multirow{2}{*}{ C } & Concentration & 1774.20 & 1810.58 & 3599.07 & 4590.32 \\
\cline { 2 - 6 } & Std. Err. & 19.28 & 65.00 & 146.01 & 195.74 \\
\hline
\end{tabular}




\section{Appendix S: Percentage of IP and OP in Bottom Sediment}

\section{Mean Concentrations of IP and OP Fractions}

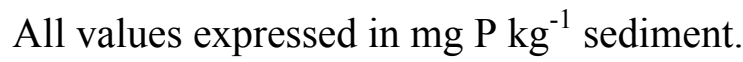

Concentrations of OP fraction were determined by difference between IP and TP (Appendix J).

Hydro East Pond

\begin{tabular}{|l|c|c|c|c|c|}
\hline & 08-Apr & 31-May & 14-Jul & 16-Sep & 05-Nov \\
\hline Concentration of IP & 462.23 & 480.48 & 561.42 & 595.14 & 541.18 \\
\hline Std. Err. & 4.77 & 24.41 & 38.44 & 24.69 & 5.61 \\
\hline Concentration of OP & 422.13 & 299.96 & 539.14 & 431.79 & 433.51 \\
\hline
\end{tabular}

Mattamy Rouge Pond

\begin{tabular}{|l|c|c|c|c|c|}
\hline & 08-Apr & 31-May & $14-\mathrm{Jul}$ & $16-\mathrm{Sep}$ & 05-Nov \\
\hline Concentration of IP & 793.13 & 411.84 & 565.39 & 413.03 & 495.16 \\
\hline Std. Err. & 5.89 & 1.68 & 8.14 & 5.33 & 7.29 \\
\hline Concentration of OP & 361.76 & 257.60 & 251.95 & 246.29 & 299.32 \\
\hline
\end{tabular}

\section{Percent IP and OP}

All values expressed as percentages.

Hydro East Pond

\begin{tabular}{|l|c|c|c|c|c|}
\hline & 08-Apr & 31-May & 14-Jul & 16-Sep & 05-Nov \\
\hline \% IP & 52.27 & 61.56 & 51.01 & 57.95 & 55.52 \\
\hline$\%$ OP & 47.73 & 38.44 & 48.99 & 42.05 & 44.48 \\
\hline
\end{tabular}

Mattamy Rouge Pond

\begin{tabular}{|l|c|c|c|c|c|}
\hline & 08-Apr & 31-May & 14-Jul & 16-Sep & 05-Nov \\
\hline \% IP & 68.68 & 61.52 & 69.17 & 62.64 & 62.32 \\
\hline \% OP & 31.32 & 38.48 & 30.83 & 37.36 & 37.68 \\
\hline
\end{tabular}




\section{Appendix T: Percentage of IP and OP in Sediment Collected from Sediment Traps}

\section{Mean Concentrations of IP and OP Fractions}

All values expressed in $\mathrm{mg} \mathrm{P} \mathrm{kg}^{-1}$ sediment.

Concentrations of OP fraction were determined by difference between IP and TP (Appendix J).

Hydro East Pond

\begin{tabular}{|c|l|c|c|c|c|}
\hline Trap Location & & $27-\mathrm{Jul}$ & $19-\mathrm{Aug}$ & $16-\mathrm{Sep}$ & $05-\mathrm{Nov}$ \\
\hline \multirow{3}{*}{$\mathrm{A}$} & Concentration of IP & 643.55 & 796.70 & 1174.81 & 966.12 \\
\cline { 2 - 5 } & Std. Err. & 14.59 & 56.11 & 16.55 & 43.49 \\
\cline { 2 - 5 } & Concentration of OP & 700.11 & 692.81 & 2937.81 & 2287.60 \\
\hline \multirow{3}{*}{$\mathrm{B}$} & Concentration & 1085.94 & 1701.32 & 2453.98 & 336.45 \\
\cline { 2 - 6 } & Std. Err. & 15.99 & 67.33 & 63.12 & 25.25 \\
\cline { 2 - 6 } & Concentration of OP & 1215.50 & 970.56 & 108.05 & 2061.52 \\
\hline \multirow{3}{*}{$\mathrm{C}$} & Concentration & 2132.60 & 4046.58 & 3668.47 & 1281.94 \\
\cline { 2 - 6 } & Std. Err. & 165.81 & 76.59 & 49.94 & 54.15 \\
\cline { 2 - 6 } & Concentration of OP & 1802.76 & 1757.98 & 449.93 & 2556.24 \\
\hline
\end{tabular}

Mattamy Rouge Pond

\begin{tabular}{|c|l|c|c|c|c|}
\hline Trap Location & & $27-J u l$ & $19-A u g$ & $16-S e p$ & $05-$ Nov \\
\hline \multirow{3}{*}{$A$} & Concentration of IP & 582.84 & 734.41 & 877.24 & 891.13 \\
\cline { 2 - 6 } & Std. Err. & 27.77 & 39.56 & 49.66 & 6.17 \\
\cline { 2 - 6 } & Concentration of OP & 391.02 & 571.50 & 2277.88 & 2126.38 \\
\hline \multirow{3}{*}{$\mathrm{B}$} & Concentration & 575.70 & 805.03 & 799.08 & 1081.57 \\
\cline { 2 - 6 } & Std. Err. & 8.70 & 26.65 & 72.94 & 11.22 \\
\cline { 2 - 6 } & Concentration of OP & 960.60 & 858.57 & 2897.54 & 2523.30 \\
\hline \multirow{3}{*}{$\mathrm{C}$} & Concentration & 637.20 & 819.31 & 753.06 & 1079.99 \\
\cline { 2 - 6 } & Std. Err. & 11.78 & 33.39 & 44.33 & 33.67 \\
\cline { 2 - 6 } & Concentration of OP & 1137.00 & 991.27 & 2846.02 & 3510.33 \\
\hline
\end{tabular}

\section{Percent IP and $\mathrm{OP}$}

All values expressed as percentages.

Hydro East Pond

\begin{tabular}{|l|c|c|c|c|}
\hline & 27-Jul & $19-$ Aug & $16-$ Sep & 05-Nov \\
\hline \% IP & 50.95 & 65.67 & 67.61 & 27.23 \\
\hline \% OP & 49.05 & 34.33 & 32.39 & 72.77 \\
\hline
\end{tabular}

Mattamy Rouge Pond

\begin{tabular}{|l|c|c|c|c|}
\hline & 27-Jul & $19-$ Aug & $16-S e p$ & $05-$ Nov \\
\hline \% IP & 41.91 & 49.35 & 23.25 & 27.23 \\
\hline \% OP & 58.09 & 50.65 & 76.75 & 72.77 \\
\hline
\end{tabular}




\section{Appendix U: Mean Concentrations and Percentage of BAP in Bottom Sediment and in Sediment Collected from Sediment Traps}

\section{Bottom Sediment}

Hydro East Pond

\begin{tabular}{|l|c|c|c|c|c|}
\hline & 08-Apr & 31-May & 14-Jul & 16-Sep & 05-Nov \\
\hline Concentration $\left(\mathrm{mg} \mathrm{P} \mathrm{kg}^{-1}\right)$ & 96.90 & 31.77 & 2.68 & 0.28 & 0.00 \\
\hline Std. Err. & 0.62 & 0.28 & 0.52 & 0.16 & 0.00 \\
\hline Concentration $\left(\mathrm{mol} \mathrm{L}^{-1}\right)$ & 4.07 & 1.33 & 0.11 & 0.01 & 0.00 \\
\hline Std. Err. & 0.03 & 0.01 & 0.02 & 0.01 & 0.00 \\
\hline$\%$ BAP & 10.96 & 4.07 & 0.24 & 0.03 & 0.00 \\
\hline
\end{tabular}

Mattamy Rouge Pond

\begin{tabular}{|l|c|c|c|c|c|}
\hline & 08-Apr & 31-May & 14-Jul & 16-Sep & 05-Nov \\
\hline Concentration $\left(\mathrm{mg} \mathrm{P} \mathrm{kg}^{-1}\right)$ & 127.23 & 32.05 & 0.00 & 0.00 & 0.00 \\
\hline Std. Err. & 3.21 & 1.33 & 0.00 & 0.00 & 0.00 \\
\hline Concentration $\left(\mathrm{mol} \mathrm{L}^{-1}\right)$ & 5.34 & 1.35 & 0.00 & 0.00 & 0.00 \\
\hline Std. Err. & 0.13 & 0.06 & 0.00 & 0.00 & 0.00 \\
\hline$\%$ BAP & 11.02 & 4.79 & 0.00 & 0.00 & 0.00 \\
\hline
\end{tabular}

\section{Sediment Collected from Sediment Traps}

All concentrations expressed as $\mathrm{mg} \mathrm{P} \mathrm{kg}^{-1}$ sediment.

Hydro East Pond

\begin{tabular}{|c|l|c|c|c|c|}
\hline Trap Location & & 27-Jul & $19-A u g$ & 16-Sep & 05-Nov \\
\hline \multirow{2}{*}{$\mathrm{A}$} & Concentration & 0 & 53.09 & 0 & 0 \\
\cline { 2 - 5 } & Std. Err. & 0 & 3.05 & 0 & 0 \\
\hline \multirow{2}{*}{$\mathrm{B}$} & Concentration & 4.06 & 69.46 & 14.02 & 0.00 \\
\cline { 2 - 6 } & Std. Err. & 0.68 & 4.45 & 1.89 & 0.00 \\
\hline \multirow{2}{*}{$\mathrm{C}$} & Concentration & 20.22 & 0.00 & 0.00 & 0.00 \\
\cline { 2 - 6 } & Std. Err. & 0.73 & 0.00 & 0.00 & 0.00 \\
\hline \multirow{2}{*}{ Mean } & \% BAP & 0.32 & 1.23 & 0.13 & 0.00 \\
\hline
\end{tabular}

Mattamy Rouge Pond

\begin{tabular}{|c|l|c|c|c|c|}
\hline Trap Location & & 27-Jul & $19-A u g$ & $16-$ Sep & 05-Nov \\
\hline \multirow{2}{*}{$\mathrm{A}$} & Concentration & 17.61 & 7.01 & 85.17 & 88.87 \\
\cline { 2 - 6 } & Std. Err. & 9.93 & 2.08 & 7.55 & 2.32 \\
\hline \multirow{2}{*}{$\mathrm{B}$} & Concentration & 38.99 & 150.37 & 63.35 & 101.97 \\
\cline { 2 - 6 } & Std. Err. & 1.81 & 5.84 & 2.28 & 4.30 \\
\hline \multirow{2}{*}{$\mathrm{C}$} & Concentration & 84.45 & 80.68 & 54.89 & 121.81 \\
\cline { 2 - 6 } & Std. Err. & 2.23 & 9.63 & 3.61 & 4.21 \\
\hline \multirow{2}{*}{ Mean } & \% BAP & 3.29 & 4.98 & 1.95 & 2.79 \\
\hline
\end{tabular}




\section{Appendix V: Mean Concentrations of TN in Bottom Sediment and in Sediment Collected from Sediment Traps}

\section{Bottom Sediment}

Hydro East Pond

\begin{tabular}{|l|c|c|c|c|c|}
\hline & 08-Apr & 31-May & 14-Jul & 16-Sep & 05-Nov \\
\hline Concentration $\left(\mathrm{mg} \mathrm{N} \mathrm{kg}^{-1}\right)$ & 344.00 & 352.50 & 215.00 & 107.50 & 167.25 \\
\hline Std. Err. & 0.55 & 0.40 & 9.91 & 0.12 & 0.59 \\
\hline Concentration $\left(\mathrm{mol} \mathrm{L}^{-1}\right)$ & 31.93 & 32.72 & 19.95 & 9.98 & 15.52 \\
\hline Std. Err. & 0.051 & 0.038 & 0.920 & 0.011 & 0.055 \\
\hline
\end{tabular}

Mattamy Rouge Pond

\begin{tabular}{|l|c|c|c|c|c|}
\hline & 08-Apr & 31-May & 14-Jul & 16-Sep & 05-Nov \\
\hline Concentration $\left(\mathrm{mg} \mathrm{N} \mathrm{kg}^{-1}\right)$ & 86.00 & 78.00 & 144.00 & 140.00 & 266.00 \\
\hline Std. Err. & 0.55 & 0.10 & 0.44 & 1.19 & 0.10 \\
\hline Concentration $\left(\mathrm{mol} \mathrm{L}^{-1}\right)$ & 7.98 & 7.24 & 13.37 & 12.99 & 24.69 \\
\hline Std. Err. & 0.051 & 0.010 & 0.041 & 0.110 & 0.009 \\
\hline
\end{tabular}

\section{Sediment Collected from Sediment Traps}

All values expressed in $\mathrm{mg} \mathrm{N} \mathrm{kg}^{-1}$ sediment.

Hydro East Pond

\begin{tabular}{|c|l|c|c|c|c|}
\hline Trap Location & & 27-Jul & $19-A u g$ & $16-$ Sep & 05-Nov \\
\hline \multirow{2}{*}{ A } & Concentration & 203 & 103.75 & 1881 & 28 \\
\cline { 2 - 6 } & Std. Err. & 2.74 & 0.10 & 4.19 & 0.65 \\
\hline \multirow{2}{*}{ B } & Concentration & 50.75 & 1807.25 & 130.25 & 48.5 \\
\cline { 2 - 6 } & Std. Err. & 0.25 & 4.65 & 1.75 & 1.12 \\
\hline \multirow{2}{*}{ C } & Concentration & 67.75 & 183.25 & 1045.5 & 132.25 \\
\cline { 2 - 6 } & Std. Err. & 0.27 & 2.66 & 1.71 & 3.05 \\
\hline
\end{tabular}

Mattamy Rouge Pond

\begin{tabular}{|c|l|c|c|c|c|}
\hline Trap Location & & 27-Jul & 19-Aug & 16-Sep & 05-Nov \\
\hline \multirow{2}{*}{ A } & Concentration & 270.5 & 565 & 604 & 57.75 \\
\cline { 2 - 6 } & Std. Err. & 0.25 & 0.70 & 1.49 & 1.33 \\
\hline \multirow{3}{*}{ B } & Concentration & 399 & 1470 & 323 & 26.25 \\
\cline { 2 - 6 } & Std. Err. & 0.92 & 2.45 & 0.28 & 0.61 \\
\hline \multirow{2}{*}{ C } & Concentration & 111.5 & 182.75 & 446.5 & 12.5 \\
\cline { 2 - 6 } & Std. Err. & 0.14 & 1.29 & 0.76 & 0.29 \\
\hline
\end{tabular}




\section{Appendix W: Nutrient Loading and Retention Calculations in HEP and MAT}

$Q=2.78 \times 0.65 \times I \times S A$

\section{Loading and Retention of TP}

Hydro East Pond

\begin{tabular}{|c|c|c|c|c|c|c|c|c|c|c|c|c|c|c|}
\hline & $\begin{array}{c}\text { Inlet } \\
(\mathrm{mmol} \\
\mathrm{m}-3)\end{array}$ & $\begin{array}{c}\text { Outlet } \\
(\mathrm{mmol} \\
\mathrm{m}-3)\end{array}$ & $\begin{array}{c}\text { mm rain } \\
\text { (previous } \\
15 \mathrm{~d} \text { ) }\end{array}$ & $\begin{array}{c}\mathrm{I} \\
(\mathrm{mm} / \mathrm{h})\end{array}$ & $\begin{array}{c}\mathrm{Q} \\
(\mathrm{L} / \mathrm{s})\end{array}$ & $\begin{array}{c}\text { Inflow } \\
\text { (m3 } \\
\text { d-1) }\end{array}$ & $\begin{array}{c}\text { Loading } \\
\text { (mmol } \\
\mathrm{d}-1)\end{array}$ & $\begin{array}{c}\text { Export } \\
\text { (mmol } \\
\text { d-1) }\end{array}$ & $\begin{array}{c}\text { Pond } \\
\text { Volume } \\
(\mathrm{m} 3)\end{array}$ & $\begin{array}{c}\text { Retention } \\
\text { Time (d) }\end{array}$ & $\begin{array}{c}\text { Net } \\
\text { Retention } \\
(\mathrm{mmol})\end{array}$ & $\begin{array}{c}\text { Net } \\
\text { Retention } \\
(\mathrm{d}-1)\end{array}$ & $\begin{array}{l}\text { Net Flux to } \\
\text { Sediment } \\
\text { (mmol P d- } \\
1)\end{array}$ & $\begin{array}{c}\text { Burial } \\
\text { (mmol P } \\
\mathrm{d}-1)\end{array}$ \\
\hline 08-Apr & 4.68 & 2.36 & 84.55 & 0.23 & 27.03 & 2335 & 10919 & 5502 & 8845 & 3.79 & 20521 & 5417 & - & - \\
\hline 20-Apr & 0.16 & 1.04 & 17.75 & 0.05 & 5.67 & 490 & 79 & 512 & 8121 & 16.57 & -7176 & -433 & - & - \\
\hline 05-May & 1.63 & 0.45 & 18.00 & 0.05 & 5.75 & 497 & 812 & 225 & 8316 & 16.73 & 9829 & 588 & - & - \\
\hline 12-May & 0.40 & 1.60 & 22.50 & 0.06 & 7.19 & 621 & 251 & 993 & 8152 & 13.12 & -9733 & -742 & - & - \\
\hline 31-May & 1.64 & 1.22 & 12.25 & 0.03 & 3.92 & 338 & 554 & 413 & 6917 & 20.45 & 2889 & 141 & - & - \\
\hline 01-Jun & 1.62 & 1.39 & 12.25 & 0.03 & 3.92 & 338 & 547 & 469 & 6917 & 20.45 & 1594 & 78 & - & - \\
\hline 07-Jun & 3.31 & 4.44 & 23.75 & 0.07 & 7.59 & 656 & 2170 & 2913 & 7383 & 11.26 & -8362 & -743 & - & - \\
\hline 08-Jul & 2.46 & 4.93 & 6.50 & 0.02 & 2.08 & 180 & 442 & 886 & 7552 & 42.07 & -18675 & -444 & - & - \\
\hline 27-Jul & 6.16 & 4.82 & 32.75 & 0.09 & 10.47 & 904 & 5569 & 4363 & 7720 & 8.54 & 10295 & 1206 & 306.85 & 899 \\
\hline 19-Aug & 1.84 & 2.17 & 64.25 & 0.18 & 20.54 & 1774 & 3272 & 3850 & 7230 & 4.07 & -2354 & -578 & 601.39 & -1179 \\
\hline 16-Sep & 1.33 & 1.26 & 24.25 & 0.07 & 7.75 & 670 & 893 & 843 & 6954 & 10.38 & 520 & 50 & 638.42 & -588 \\
\hline 05-Nov & 0.31 & 0.53 & 34.25 & 0.10 & 10.95 & 946 & 289 & 505 & 7181 & 7.59 & -1635 & -215 & 554.03 & -769 \\
\hline 12-Dec & 0.60 & 1.17 & 22.00 & 0.06 & 7.03 & 608 & 366 & 709 & 7181 & 11.82 & -4064 & -344 & - & - \\
\hline
\end{tabular}

Total retention (season) (mmol)

Total retention (season) per ha of catchment (mmol ha-1)

Daily avg retention (mmol ha-1 d-1)
$-6351.60$

$-99.74$

7471.67
Total retention (season) $(\mathrm{kg}) \quad-0.20$

Total retention (season) per ha of catchment ( $\mathrm{g}$ ha-1) $\quad-3.09$

Daily avg retention (g ha-1 d-1) 231.62 
Mattamy Rouge Pond

\begin{tabular}{|c|c|c|c|c|c|c|c|c|c|c|c|c|c|c|}
\hline & $\begin{array}{c}\text { Inlet } \\
(\mathrm{mmol} \\
\mathrm{m}-3)\end{array}$ & $\begin{array}{c}\text { Outlet } \\
(\mathrm{mmol} \\
\mathrm{m}-3)\end{array}$ & $\begin{array}{c}\text { mm rain } \\
\text { (previous } \\
15 \mathrm{~d} \text { ) }\end{array}$ & $\begin{array}{c}\mathrm{I} \\
(\mathrm{mm} / \mathrm{h})\end{array}$ & $\begin{array}{c}\mathrm{Q} \\
(1 / \mathrm{s}) \\
\end{array}$ & $\begin{array}{c}\text { Inflow } \\
(\mathrm{m} 3 \\
\mathrm{d}-1)\end{array}$ & $\begin{array}{c}\text { Loading } \\
\text { (mmol } \\
\mathrm{d}-1)\end{array}$ & $\begin{array}{c}\text { Export } \\
\text { (mmol } \\
\text { d-1) }\end{array}$ & $\begin{array}{c}\text { Pond } \\
\text { Volume } \\
(\mathrm{m} 3)\end{array}$ & $\begin{array}{c}\text { Retention } \\
\text { Time }(\mathrm{d})\end{array}$ & $\begin{array}{c}\text { Net } \\
\text { Retention } \\
(\mathrm{mmol})\end{array}$ & $\begin{array}{c}\text { Net } \\
\text { Retention } \\
(\mathrm{d}-1)\end{array}$ & $\begin{array}{l}\text { Net Flux to } \\
\text { Sediment } \\
(\mathrm{mmol} P \mathrm{~d}- \\
1)\end{array}$ & $\begin{array}{c}\text { Burial } \\
\text { (mmol P } \\
\mathrm{d}-1)\end{array}$ \\
\hline 08-Apr & 3.66 & 4.50 & 84.55 & 0.23 & 20.54 & 1775 & 6493 & 7987 & 11622.19 & 6.55 & -9789 & -1495 & - & - \\
\hline 20-Apr & 0.56 & 0.36 & 17.75 & 0.05 & 4.31 & 373 & 208 & 135 & 12728.43 & 34.16 & 2499 & 73 & - & - \\
\hline 05-May & 3.70 & 1.56 & 18.00 & 0.05 & 4.37 & 378 & 1399 & 590 & 12624.07 & 33.41 & 27024 & 809 & - & - \\
\hline 12-May & 1.02 & 3.23 & 22.50 & 0.06 & 5.47 & 472 & 481 & 1526 & 13096.55 & 27.73 & -28983 & -1045 & - & - \\
\hline 31-May & 3.36 & 2.96 & 12.25 & 0.03 & 2.98 & 257 & 864 & 761 & 12722.74 & 49.48 & 5131 & 104 & - & - \\
\hline 01-Jun & 3.75 & 3.92 & 12.25 & 0.03 & 2.98 & 257 & 964 & 1007 & 12722.74 & 49.48 & -2138 & -43 & - & - \\
\hline 07-Jun & 5.79 & 8.78 & 23.75 & 0.07 & 5.77 & 499 & 2886 & 4378 & 13690.46 & 27.46 & -40977 & -1492 & - & - \\
\hline 08-Jul & 7.83 & 8.39 & 6.50 & 0.02 & 1.58 & 136 & 1068 & 1145 & 12944.75 & 94.88 & -7324 & -77 & - & - \\
\hline 27-Jul & 6.87 & 6.80 & 32.75 & 0.09 & 7.96 & 687 & 4721 & 4675 & 13350.81 & 19.42 & 886 & 46 & 505.53 & -460 \\
\hline 19-Aug & 5.23 & 4.29 & 64.25 & 0.18 & 15.61 & 1349 & 7060 & 5789 & 12075.69 & 8.95 & 11377 & 1271 & 1085.53 & 185 \\
\hline 16-Sep & 0.60 & 1.28 & 24.25 & 0.07 & 5.89 & 509 & 303 & 652 & 13214.19 & 25.96 & -9069 & -349 & 980.16 & -1329 \\
\hline 05-Nov & 0.63 & 0.74 & 34.25 & 0.10 & 8.32 & 719 & 454 & 535 & 12614.58 & 17.55 & -1436 & -82 & 745.33 & -827 \\
\hline 12-Dec & 1.30 & 1.39 & 22.00 & 0.06 & 5.34 & 462 & 601 & 643 & 12614.58 & 27.32 & -1149 & -42 & - & - \\
\hline
\end{tabular}

Total retention (season) ( $\mathrm{mmol})$

$-53948.00$

Total retention (season) $(\mathrm{kg})$

$-1.67$

Total retention (season) per ha of catchment (mmol ha-1)

$-1114.63$

Daily avg retention (mmol ha- $1 \mathrm{~d}-1)$

$-3061.72$

Total retention (season) per ha of catchment ( $\mathrm{g}$ ha-1) $\quad-34.55$

Daily avg retention (g ha-1 d-1) -94.91 


\section{Loading and Retention of TN}

\section{Hydro East Pond}

\begin{tabular}{|c|c|c|c|c|c|c|c|c|c|c|c|c|c|c|}
\hline & $\begin{array}{c}\text { Inlet } \\
(\mathrm{mmol} \\
\mathrm{m}-3)\end{array}$ & $\begin{array}{c}\text { Outlet } \\
(\mathrm{mmol} \\
\mathrm{m}-3)\end{array}$ & $\begin{array}{c}\text { mm rain } \\
\text { (previous } \\
15 \mathrm{~d} \text { ) }\end{array}$ & $\begin{array}{c}\mathrm{I} \\
(\mathrm{mm} / \mathrm{h})\end{array}$ & $\begin{array}{c}\mathrm{Q} \\
(1 / \mathrm{s}) \\
\end{array}$ & $\begin{array}{c}\text { Inflow } \\
(\mathrm{m} 3 \\
\mathrm{d}-1)\end{array}$ & $\begin{array}{c}\text { Loading } \\
\text { (mmol } \\
\mathrm{d}-1)\end{array}$ & $\begin{array}{c}\text { Export } \\
\text { (mmol } \\
\text { d-1) }\end{array}$ & $\begin{array}{c}\text { Pond } \\
\text { Volume } \\
(\mathrm{m} 3)\end{array}$ & $\begin{array}{c}\text { Retention } \\
\text { Time (d) }\end{array}$ & $\begin{array}{c}\text { Net } \\
\text { Retention } \\
(\mathrm{mmol})\end{array}$ & $\begin{array}{c}\text { Net } \\
\text { Retention } \\
(\mathrm{d}-1)\end{array}$ & $\begin{array}{l}\text { Net Flux to } \\
\text { Sediment } \\
\text { (mmol P d- } \\
1)\end{array}$ & $\begin{array}{c}\text { Burial } \\
\text { (mmol P } \\
\mathrm{d}-1)\end{array}$ \\
\hline 08-Apr & 213 & 176 & 84.55 & 0.23 & 27.03 & 2335 & 497526 & 411496 & 8845 & 3.79 & 325875 & 86030 & - & - \\
\hline 20-Apr & 101 & 61 & 17.75 & 0.05 & 5.67 & 490 & 49361 & 29932 & 8121 & 16.57 & 321878 & 19428 & - & - \\
\hline 05-May & 115 & 119 & 18.00 & 0.05 & 5.75 & 497 & 57089 & 59131 & 8316 & 16.73 & -34154 & -2042 & - & - \\
\hline 12-May & 51 & 70 & 22.50 & 0.06 & 7.19 & 621 & 31452 & 43374 & 8152 & 13.12 & -156404 & -11922 & - & - \\
\hline 31-May & 46 & 43 & 12.25 & 0.03 & 3.92 & 338 & 15578 & 14439 & 6917 & 20.45 & 23296 & 1139 & - & - \\
\hline 01-Jun & 96 & 73 & 12.25 & 0.03 & 3.92 & 338 & 32469 & 24807 & 6917 & 20.45 & 156640 & 7661 & - & - \\
\hline 07-Jun & 96 & 91 & 23.75 & 0.07 & 7.59 & 656 & 62861 & 59721 & 7383 & 11.26 & 35341 & 3140 & - & - \\
\hline 08-Jul & 99 & 85 & 6.50 & 0.02 & 2.08 & 180 & 17840 & 15201 & 7552 & 42.07 & 111010 & 2639 & - & - \\
\hline 27-Jul & 71 & 46 & 32.75 & 0.09 & 10.47 & 904 & 64553 & 41642 & 7720 & 8.54 & 195576 & 22912 & 6284.32 & 16628 \\
\hline 19-Aug & 101 & 28 & 64.25 & 0.18 & 20.54 & 1774 & 178560 & 50531 & 7230 & 4.07 & 521686 & 128029 & 61017.73 & 67011 \\
\hline 16-Sep & 84 & 31 & 24.25 & 0.07 & 7.75 & 670 & 56393 & 20990 & 6954 & 10.38 & 367635 & 35403 & 65804.40 & -30401 \\
\hline 05-Nov & 152 & 118 & 34.25 & 0.10 & 10.95 & 946 & 143611 & 111368 & 7181 & 7.59 & 244776 & 32242 & 4730.34 & 27512 \\
\hline 12-Dec & 205 & 127 & 22.00 & 0.06 & 7.03 & 608 & 124708 & 77434 & 7181 & 11.82 & 558735 & 47274 & - & - \\
\hline
\end{tabular}

Total retention (season) $(\mathrm{mmol})$

Total retention (season) per ha of catchment (mmol ha-1)

Daily avg retention (mmol ha-1 d-1)
2671889.10

41958.06

697944.13
Total retention (season) $(\mathrm{kg})$

Total retention (season) per ha of catchment ( $\mathrm{g}$ ha-1)

Daily avg retention (g ha-1 d-1)
37.41

587.41

9771.22 
Mattamy Rouge Pond

\begin{tabular}{|c|c|c|c|c|c|c|c|c|c|c|c|c|c|c|}
\hline & $\begin{array}{c}\text { Inlet } \\
(\mathrm{mmol} \\
\mathrm{m}-3)\end{array}$ & $\begin{array}{c}\text { Outlet } \\
(\mathrm{mmol} \\
\mathrm{m}-3)\end{array}$ & $\begin{array}{c}\text { mm rain } \\
\text { (previous } \\
15 \mathrm{~d} \text { ) }\end{array}$ & $\begin{array}{c}\mathrm{I} \\
(\mathrm{mm} / \mathrm{h})\end{array}$ & $\begin{array}{c}\mathrm{Q} \\
(1 / \mathrm{s}) \\
\end{array}$ & $\begin{array}{c}\text { Inflow } \\
\text { (m3 } \\
\text { d-1) }\end{array}$ & $\begin{array}{c}\text { Loading } \\
\text { (mmol } \\
\mathrm{d}-1)\end{array}$ & $\begin{array}{c}\text { Export } \\
\text { (mmol } \\
\text { d-1) }\end{array}$ & $\begin{array}{l}\text { Pond } \\
\text { Volume } \\
(\mathrm{m} 3)\end{array}$ & $\begin{array}{c}\text { Retention } \\
\text { Time (d) }\end{array}$ & $\begin{array}{c}\text { Net } \\
\text { Retention } \\
(\mathrm{mmol}) \\
\end{array}$ & $\begin{array}{c}\text { Net } \\
\text { Retention } \\
(\mathrm{d}-1)\end{array}$ & $\begin{array}{l}\text { Net Flux to } \\
\text { Sediment } \\
\text { (mmol P d- } \\
1)\end{array}$ & $\begin{array}{c}\text { Burial } \\
\text { (mmol P } \\
\mathrm{d}-1)\end{array}$ \\
\hline 08-Apr & 213 & 176 & 84.55 & 0.23 & 27.03 & 2335 & 497526 & 411496 & 8845 & 3.79 & 325875 & 86030 & - & - \\
\hline 20-Apr & 101 & 61 & 17.75 & 0.05 & 5.67 & 490 & 49361 & 29932 & 8121 & 16.57 & 321878 & 19428 & - & - \\
\hline 05-May & 115 & 119 & 18.00 & 0.05 & 5.75 & 497 & 57089 & 59131 & 8316 & 16.73 & -34154 & -2042 & - & - \\
\hline 12-May & 51 & 70 & 22.50 & 0.06 & 7.19 & 621 & 31452 & 43374 & 8152 & 13.12 & -156404 & -11922 & - & - \\
\hline 31-May & 46 & 43 & 12.25 & 0.03 & 3.92 & 338 & 15578 & 14439 & 6917 & 20.45 & 23296 & 1139 & - & - \\
\hline 01-Jun & 96 & 73 & 12.25 & 0.03 & 3.92 & 338 & 32469 & 24807 & 6917 & 20.45 & 156640 & 7661 & - & - \\
\hline 07-Jun & 96 & 91 & 23.75 & 0.07 & 7.59 & 656 & 62861 & 59721 & 7383 & 11.26 & 35341 & 3140 & - & - \\
\hline 08-Jul & 99 & 85 & 6.50 & 0.02 & 2.08 & 180 & 17840 & 15201 & 7552 & 42.07 & 111010 & 2639 & - & - \\
\hline 27-Jul & 71 & 46 & 32.75 & 0.09 & 10.47 & 904 & 64553 & 41642 & 7720 & 8.54 & 195576 & 22912 & 6284.32 & 16628 \\
\hline 19-Aug & 101 & 28 & 64.25 & 0.18 & 20.54 & 1774 & 178560 & 50531 & 7230 & 4.07 & 521686 & 128029 & 61017.73 & 67011 \\
\hline 16-Sep & 84 & 31 & 24.25 & 0.07 & 7.75 & 670 & 56393 & 20990 & 6954 & 10.38 & 367635 & 35403 & 65804.40 & -30401 \\
\hline 05-Nov & 152 & 118 & 34.25 & 0.10 & 10.95 & 946 & 143611 & 111368 & 7181 & 7.59 & 244776 & 32242 & 4730.34 & 27512 \\
\hline 12-Dec & 205 & 127 & 22.00 & 0.06 & 7.03 & 608 & 124708 & 77434 & 7181 & 11.82 & 558735 & 47274 & - & - \\
\hline
\end{tabular}

Total retention (season) ( $\mathrm{mmol})$

Total retention (season) per ha of catchment (mmol ha-1)

Daily avg retention (mmol ha- $1 \mathrm{~d}-1)$
$-263787.11$

$-5450.15$

24229.50
Total retention (season) $(\mathrm{kg}) \quad-3.69$

Total retention (season) per ha of catchment ( $\mathrm{g}$ ha-1) $\quad-76.30$

Daily avg retention (g ha-1 d-1) 993.41 


\section{Appendix X: Sediment Deposition Rates}

Hydro East Pond
\begin{tabular}{|l|c|c|c|c|}
\hline Trap Location & July 14 - July 27 & July 27 - Aug. 19 & Aug. 19 - Sept. 16 & Sept. 16 - Nov. 5 \\
\hline A $\left(\mathrm{cm} \mathrm{d}^{-1}\right)$ & 0.013 & 0.015 & 0.011 & 0.016 \\
\hline B $\left(\mathrm{cm} \mathrm{d}^{-1}\right)$ & 0.01 & 0.017 & 0.019 & 0.017 \\
\hline C $\left(\mathrm{cm} \mathrm{d}^{-1}\right)$ & 0.009 & 0.013 & 0.015 & 0.012 \\
\hline \multicolumn{5}{|l|}{} \\
\hline Mean $\left(\mathrm{cm} \mathrm{d}^{-1}\right)$ & 0.011 & 0.015 & 0.015 & 0.015 \\
\hline Std. Err. & 0.0012 & 0.0012 & 0.0024 & 0.0017 \\
\hline Mean $\left(\mathrm{cm} \mathrm{yr}^{-1}\right)$ & 3.94 & 5.56 & 5.46 & 5.43 \\
\hline Std. Err. & 0.44 & 0.45 & 0.87 & 0.64 \\
\hline
\end{tabular}

\section{Mattamy Rouge Pond}

\begin{tabular}{|l|c|c|c|c|}
\hline Trap Location & July 14 - July 27 & July 27 - Aug. 19 & Aug. 19 - Sept. 16 & Sept. 16 - Nov. 5 \\
\hline $\mathrm{A}\left(\mathrm{cm} \mathrm{d}^{-1}\right)$ & 0.038 & 0.023 & 0.021 & 0.014 \\
\hline $\mathrm{B}\left(\mathrm{cm} \mathrm{d}^{-1}\right)$ & 0.02 & 0.014 & 0.019 & 0.013 \\
\hline $\mathrm{C}\left(\mathrm{cm} \mathrm{d}^{-1}\right)$ & 0.009 & 0.013 & 0.017 & 0.012 \\
\hline \multicolumn{5}{|l|}{} \\
\hline Mean $\left(\mathrm{cm} \mathrm{d}^{-1}\right)$ & 0.023 & 0.017 & 0.019 & 0.013 \\
\hline Std. Err. & 0.0085 & 0.0031 & 0.0014 & 0.0006 \\
\hline Mean $\left(\mathrm{cm} \mathrm{yr}^{-1}\right)$ & 8.24 & 6.11 & 6.90 & 4.81 \\
\hline Std. Err. & 3.08 & 1.12 & 0.50 & 0.20 \\
\hline
\end{tabular}




\section{Appendix Y: Weather Data (Daily Total Precipitation and Average Temperature)}

\begin{tabular}{|c|c|c|c|c|c|}
\hline Date & $\begin{array}{l}\text { Total Precip. } \\
(\mathrm{mm})\end{array}$ & $\begin{array}{c}\text { Avg. Temp. } \\
\left({ }^{\circ} \mathrm{C}\right)\end{array}$ & Date & $\begin{array}{l}\text { Total Precip. } \\
(\mathrm{mm})\end{array}$ & $\begin{array}{c}\text { Avg. Temp. } \\
\left({ }^{\circ} \mathrm{C}\right)\end{array}$ \\
\hline 25-Mar & 3 & -0.86 & 06-May & 0 & 15.32 \\
\hline 26-Mar & 7.75 & 0.463 & 07-May & 0 & 12.7 \\
\hline 27-Mar & 0 & 5.73 & 08-May & 4.5 & 8.52 \\
\hline 28-Mar & 17 & 5.963 & 09-May & 0 & 9.07 \\
\hline 29-Mar & 0 & 2.47 & 10-May & 0 & 11.06 \\
\hline 30-Mar & 0 & 4.638 & 11-May & 0 & 13.28 \\
\hline 31-Mar & 25.75 & 10.67 & 12-May & 0 & 15.24 \\
\hline 01-Apr & 0 & 9.15 & 13-May & 8 & 17.19 \\
\hline 02-Apr & 0 & 2.432 & 14-May & 8 & 10.27 \\
\hline 03-Apr & 12.5 & -4.347 & 15-May & 1.75 & 4.202 \\
\hline 04-Apr & 0 & -4.279 & 16-May & 10.25 & 8.68 \\
\hline 05-Apr & 2 & -3.094 & 17-May & 0.25 & 11.07 \\
\hline 06-Apr & 4 & 0.7 & 18-May & 0 & 11.59 \\
\hline 07-Apr & 2.75 & 4.668 & 19-May & 0 & 15.43 \\
\hline 08-Apr & 0 & -0.952 & 20-May & 0 & 17.27 \\
\hline 09-Apr & 0 & -3.38 & 21-May & 0 & 17.22 \\
\hline 10-Apr & 0 & -2.713 & 22-May & 0 & 17.81 \\
\hline 11-Apr & 9 & 5.872 & 23-May & 0 & 19.68 \\
\hline 12-Apr & 0 & 2.985 & 24-May & 0 & 22.19 \\
\hline 13-Apr & 0 & 2.532 & 25-May & 0 & 22.99 \\
\hline 14-Apr & 0 & 5.019 & 26-May & 1.75 & 17.92 \\
\hline 15-Apr & 0 & 7.932 & 27-May & 0 & 22.26 \\
\hline 16-Apr & 0 & 10.52 & 28-May & 0 & 22.86 \\
\hline 17-Apr & 0 & 14.92 & 29-May & 0 & 25.08 \\
\hline 18-Apr & 0 & 17.86 & 30-May & 0 & 23.31 \\
\hline 19-Apr & 0 & 10.99 & 31-May & 0 & 20.96 \\
\hline 20-Apr & 0 & 9.49 & 01-Jun & 0 & 15.95 \\
\hline 21-Apr & 1.5 & 9.98 & 02-Jun & 0 & 20.65 \\
\hline 22-Apr & 0.5 & 12.7 & 03-Jun & 0 & 20.73 \\
\hline 23-Apr & 0 & 7.628 & 04-Jun & 0 & 20.64 \\
\hline 24-Apr & 0 & 6.412 & 05-Jun & 20.5 & 18.87 \\
\hline 25-Apr & 4 & 5.917 & 06-Jun & 1.5 & 18.94 \\
\hline 26-Apr & 12 & 4.057 & 07-Jun & 1.25 & 15.99 \\
\hline 27-Apr & 0 & 6.044 & 08-Jun & 0.25 & 11.41 \\
\hline 05-May & 0 & 12.71 & 09-Jun & 0 & 13.8 \\
\hline
\end{tabular}




\begin{tabular}{|c|c|c|c|c|c|}
\hline Date & $\begin{array}{c}\text { Total Precip. } \\
(\mathrm{mm})\end{array}$ & $\begin{array}{c}\text { Avg. Temp. } \\
\left({ }^{\circ} \mathrm{C}\right)\end{array}$ & Date & $\begin{array}{c}\text { Total Precip. } \\
(\mathrm{mm})\end{array}$ & $\begin{array}{c}\text { Avg. Temp. } \\
\left({ }^{\circ} \mathrm{C}\right)\end{array}$ \\
\hline 10-Jun & 0 & 16.31 & 18-Jul & 0.75 & 25.41 \\
\hline 11-Jun & 28 & 20.77 & 19-Jul & 0 & 20.86 \\
\hline 12-Jun & 7 & 16.86 & 20-Jul & 0 & 21.02 \\
\hline 13-Jun & 0 & 14.63 & 21-Jul & 0 & 25.29 \\
\hline 14-Jun & 0 & 15.89 & 22-Jul & 0 & 28.56 \\
\hline 15-Jun & 0 & 18.27 & 23-Jul & 0 & 27.35 \\
\hline 16-Jun & 0.5 & 20.35 & 24-Jul & 0 & 22.23 \\
\hline 17-Jun & 0 & 23.81 & 25-Jul & 30.25 & 24.75 \\
\hline 18-Jun & 0 & 24.03 & 26-Jul & 0 & 23.6 \\
\hline 19-Jun & 0 & 25.08 & 27-Jul & 12.25 & 24.12 \\
\hline 20-Jun & 1.25 & 25.82 & 28-Jul & 0.5 & 24.69 \\
\hline 21-Jun & 2.75 & 20.85 & 29-Jul & 0.25 & 22.98 \\
\hline 22-Jun & 0 & 19.6 & 30-Jul & 0 & 21.77 \\
\hline 23-Jun & 0 & 19.16 & 31-Jul & 1 & 21.5 \\
\hline 24-Jun & 0 & 20.71 & 01-Aug & 0 & 23.21 \\
\hline 25-Jun & 0 & 21.78 & 02-Aug & 0 & 23.56 \\
\hline 26-Jun & 1.25 & 23.94 & 03-Aug & 0 & 23.73 \\
\hline 27-Jun & 0 & 25.86 & 04-Aug & 0 & 25.19 \\
\hline 28-Jun & 0 & 19.53 & 05-Aug & 5.25 & 26.27 \\
\hline 29-Jun & 0 & 20.3 & 06-Aug & 0 & 23.7 \\
\hline 30-Jun & 0 & 21.12 & 07-Aug & 0 & 22.39 \\
\hline 01-Jul & 5.25 & 17.63 & 08-Aug & 0 & 22.86 \\
\hline 02-Jul & 0 & 19.38 & 09-Aug & 0 & 23.36 \\
\hline 03-Jul & 0 & 22.15 & 10-Aug & 0 & 27.37 \\
\hline 04-Jul & 0 & 22.03 & 11-Aug & 0 & 27.15 \\
\hline 05-Jul & 0 & 25.01 & 12-Aug & 0 & 28.41 \\
\hline 06-Jul & 0 & 25.5 & 13-Aug & 39.75 & 23.76 \\
\hline 07-Jul & 0 & 26.53 & 14-Aug & 0 & 23.52 \\
\hline 08-Jul & 0.75 & 22.61 & 15-Aug & 0 & 21.63 \\
\hline 09-Jul & 0.5 & 22.01 & 16-Aug & 19.25 & 22.11 \\
\hline 10-Jul & 0 & 22.09 & 17-Aug & 0 & 20.56 \\
\hline 11-Jul & 0 & 21.09 & 18-Aug & 0 & 22.87 \\
\hline 12-Jul & 0 & 22.78 & 19-Aug & 0 & 23.16 \\
\hline 13-Jul & 0 & 26.47 & 20-Aug & 0.25 & 24.73 \\
\hline 14-Jul & 1.75 & 23.74 & 21-Aug & 4.25 & 22.98 \\
\hline 15-Jul & 0 & 22.33 & 22-Aug & 0 & 18.92 \\
\hline 16-Jul & 0 & 17.95 & 23-Aug & 0 & 21.67 \\
\hline 17-Jul & 0 & 20.18 & 24-Aug & 0 & 23.38 \\
\hline
\end{tabular}




\begin{tabular}{|c|c|c|c|c|c|}
\hline Date & $\begin{array}{c}\text { Total Precip. } \\
(\mathrm{mm})\end{array}$ & $\begin{array}{c}\text { Avg. Temp. } \\
\left({ }^{\circ} \mathrm{C}\right)\end{array}$ & Date & $\begin{array}{c}\text { Total Precip. } \\
(\mathrm{mm})\end{array}$ & $\begin{array}{c}\text { Avg. Temp. } \\
\left({ }^{\circ} \mathrm{C}\right)\end{array}$ \\
\hline 25-Aug & 19.75 & 24.4 & 02-Oct & 5.75 & 16.4 \\
\hline 26-Aug & 0 & 24.01 & 03-Oct & 0 & 15.91 \\
\hline 27-Aug & 0 & 21.99 & 04-Oct & 0.5 & 16.89 \\
\hline 28-Aug & 0 & 24.77 & 05-Oct & 0 & 17.06 \\
\hline 29-Aug & 0 & 22.08 & 06-Oct & 0 & 18.31 \\
\hline 30-Aug & 0 & 23.12 & 07-Oct & 0 & 17.78 \\
\hline 31-Aug & 3.75 & 23 & 08-Oct & 5.25 & 15.01 \\
\hline 01-Sep & 0 & 18.18 & 09-Oct & 0 & 9.48 \\
\hline 02-Sep & 0 & 17.92 & $10-$ Oct & 0 & 7.501 \\
\hline 03-Sep & 0 & 18.2 & 13-Oct & 0 & 12.37 \\
\hline 04-Sep & 0 & 18.95 & 14-Oct & 0 & 10.1 \\
\hline 05-Sep & 0 & 21.02 & 15-Oct & 0 & 14.5 \\
\hline 06-Sep & 0 & 23.6 & 16-Oct & 4 & 18.63 \\
\hline 07-Sep & 11.25 & 25.43 & 17-Oct & 2.25 & 15.96 \\
\hline 08-Sep & 9 & 24.94 & 18-Oct & 3 & 19.9 \\
\hline 09-Sep & 0 & 23.54 & 19-Oct & 0 & 15.51 \\
\hline 10-Sep & 4 & 22.41 & 20-Oct & 6.5 & 12.75 \\
\hline 11-Sep & 0 & 18.57 & 21-Oct & 5 & 8.7 \\
\hline 12-Sep & 0 & 18.24 & 22-Oct & 0.25 & 5.83 \\
\hline 13-Sep & 0 & 21.46 & 23-Oct & 0 & 9.07 \\
\hline 14-Sep & 0 & 18.94 & 24-Oct & 0 & 7.043 \\
\hline 15-Sep & 0 & 14.83 & 25-Oct & 0 & 5.017 \\
\hline 16-Sep & 0 & 16.94 & 26-Oct & 0 & 3.597 \\
\hline 17-Sep & 9 & 19.93 & 27-Oct & 9.5 & 2.849 \\
\hline 18-Sep & 0 & 21.06 & 28-Oct & 0 & 5.328 \\
\hline 19-Sep & 0 & 21.23 & 29-Oct & 0 & 14.26 \\
\hline 20-Sep & 0 & 22.64 & $30-$ Oct & 0.5 & 7.956 \\
\hline 21-Sep & 0.5 & 21.14 & 31-Oct & 0 & 4.578 \\
\hline 22-Sep & 0.5 & 21.57 & 01-Nov & 0 & 10.58 \\
\hline 23-Sep & 1.75 & 17.12 & 02-Nov & 1.75 & 15 \\
\hline 24-Sep & 0 & 13.68 & 03-Nov & 17.25 & 10.79 \\
\hline 25-Sep & 0 & 13 & 04-Nov & 0 & 7.458 \\
\hline 26-Sep & 8.5 & 15.33 & 05-Nov & 0 & 11.45 \\
\hline 27-Sep & 0.25 & 16.54 & 06-Nov & 0 & 9.22 \\
\hline 28-Sep & 0 & 17.81 & 07-Nov & 0 & 9.21 \\
\hline 29-Sep & 2 & 15.36 & 08-Nov & 1 & 10.21 \\
\hline 30-Sep & 0.25 & 16.17 & 09-Nov & 0 & 6.854 \\
\hline 01-Oct & 2.5 & 14.51 & 10-Nov & 0 & 9.04 \\
\hline
\end{tabular}




\begin{tabular}{|c|c|c|c|c|c|}
\hline Date & $\begin{array}{l}\text { Total Precip. } \\
\text { (mm) }\end{array}$ & $\begin{array}{l}\text { Avg. Temp. } \\
\left({ }^{\circ} \mathrm{C}\right)\end{array}$ & Date & $\begin{array}{l}\text { Total Precip. } \\
\text { ((mm) }\end{array}$ & $\begin{array}{l}\text { Avg. Temp. } \\
\left({ }^{\circ} \mathrm{C}\right)\end{array}$ \\
\hline $11-\mathrm{Nov}$ & 2.25 & 6.355 & 19-Dec & 0 & -8.18 \\
\hline $12-\mathrm{Nov}$ & 0 & 4.616 & 20-Dec & 1 & -2.717 \\
\hline 13-Nov & 0 & 8.14 & 21-Dec & 0 & -1.25 \\
\hline 14-Nov & 0 & 9.46 & & & \\
\hline 15-Nov & 0 & 7.58 & & & \\
\hline 16-Nov & 0 & 8.41 & & & \\
\hline 17-Nov & 0 & 7.967 & & & \\
\hline 18-Nov & 0 & 9.68 & & & \\
\hline 19-Nov & 3.25 & 7.963 & & & \\
\hline 20-Nov & 68.75 & 0.123 & & & \\
\hline 21-Nov & 6.5 & -1.816 & & & \\
\hline $22-\mathrm{Nov}$ & 0 & -0.776 & & & \\
\hline 23-Nov & 0 & -1.469 & & & \\
\hline 24-Nov & 3.75 & 2.33 & & & \\
\hline $25-\mathrm{Nov}$ & 0.5 & 4.656 & & & \\
\hline 26-Nov & 0 & 4.702 & & & \\
\hline 27-Nov & 0 & 4.822 & & & \\
\hline $28-\mathrm{Nov}$ & 0 & 5.243 & & & \\
\hline 29-Nov & 4.5 & 9.66 & & & \\
\hline 30-Nov & 4.75 & 8.81 & & & \\
\hline 01-Dec & 0.75 & 6.031 & & & \\
\hline 02-Dec & 0.5 & 4.224 & & & \\
\hline 03-Dec & 0 & 2.606 & & & \\
\hline 04-Dec & 0 & 0.969 & & & \\
\hline 05-Dec & 6.5 & 3.449 & & & \\
\hline 06-Dec & 4.75 & 3.456 & & & \\
\hline 07-Dec & 0.25 & 2.728 & & & \\
\hline 08-Dec & 0 & -0.224 & & & \\
\hline 09-Dec & 0 & -4.119 & & & \\
\hline 10-Dec & 0 & -5.149 & & & \\
\hline 11-Dec & 0 & -3.109 & & & \\
\hline 12-Dec & 3.25 & 0.585 & & & \\
\hline 13-Dec & 0 & -1.206 & & & \\
\hline 14-Dec & 0.25 & -6.336 & & & \\
\hline 15-Dec & 0.75 & -9.42 & & & \\
\hline 16-Dec & 0 & -8.04 & & & \\
\hline 17-Dec & 0 & -2.377 & & & \\
\hline 18-Dec & 3.5 & -5.347 & & & \\
\hline
\end{tabular}




\section{References}

American Public Health Association (2012) Standard Methods for the Examination of Water and Wastewater 22nd edn. American Public Health Association, Washington DC

Amweg EL, Weston DP, You J, Lydy MJ (2006) Pyrethroid insecticides and sediment toxicity in urban creeks from California and Tennessee. Environ Sci Technol 40(5):1700-1706.

doi:10.1021/es051407c

Arnold C, Gibbons CJ (1996) Impervious Surface Coverage - The Emergence of a Key Environmental Indicator. J Am Plann Assoc 62(2):243-258. doi:10.1080/01944369608975688

Aspila KI, Agemian H, Chau, AS (1976) A semi-automated method for the determination of inorganic, organic and total phosphate in sediments. Analyst 101(1200):187-197. doi:10.1039/an9760100187

Austin B (1988) Marine Microbiology. Cambridge University Press, Cambridge

Benson BB, Krause D (1980) The concentration and isotopic fractionation of gases dissolved in freshwater in equilibrium with the atmosphere. 1. oxygen: Oxygen in freshwater. Limnol Oceanogr 25(4):662-671. doi:10.4319/lo.1980.25.4.0662

Beutel MW (2006) Inhibition of ammonia release from anoxic profundal sediments in lakes using hypolimnetic oxygenation. Ecol Eng 28(3):271-279. doi:10.1016/j.ecoleng.2006.05.009

Bilotta GS, Brazier RE (2008) Understanding the influence of suspended solids on water quality and aquatic biota. Water Res 42(12):2849-2861. doi:10.1016/j.watres.2008.03.018

Bloesch J, Burns NM (1980) A critical review of sedimentation trap technique. Schweiz Z Hydrol 42(1):15-55. doi:10.1007/BF02502505

Borchardt D, Sperling F (1997) Urban stormwater discharges: Ecological effects on receiving waters and consequences for technical measures. Wat Sci Tech 36(8-9):173-178. doi:10.1016/S0273-1223(97)00602-1

Borden RC, Dorn JL, Liehr SK, Stillman JB (1998) Effect of in-lake water quality on pollutant removal in two ponds. J Environ Eng 124(8):737-743. doi:10.1061/(ASCE)07339372(1998)124:8(737)

Boström B, Andersen JM, Fleischer S, Jansson M (1988) Exchange of phosphorus across the sediment-water interface. Hydrobiologia 170(1):229-244. doi:10.1007/BF00024907

Boyce FM, Charlton MN, Rathke D, Mortimer CH, Bennett J (1987) Lake Erie research: Recent results, remaining gaps. J Great Lakes Res 13(4):826-840. doi:10.1016/S0380-1330(87)71693-1 
Brown JN, Peake BM (2006) Sources of heavy metals and polycyclic aromatic hydrocarbons in urban stormwater runoff. Sci Total Environ 359(1):145-155. doi:10.1016/j.scitotenv.2005.05.016

Burns MJ, Fletcher TD, Walsh CJ, Ladson AR, Hatt BE (2012) Hydrologic shortcomings of conventional urban stormwater management and opportunities for reform. Landsc Urban Plan 105(3):230-240. doi:10.1016/j.landurbplan.2011.12.012

Carpenter SR, Caraco NF, Correll DL, Howarth RW, Sharpley AN, Smith VH (1998) Nonpoint pollution of surface waters with phosphorus and nitrogen. Ecol Appl 8(3): 559-568. doi:10.1890/1051-0761(1998)008[0559:NPOSWW]2.0.CO;2

Characklis GW, Wiesner MR (1997) Particles, metals, and water quality in runoff from large urban watershed. J Environ Eng 123(8):753-759. doi:10.1061/(ASCE)07339372(1997)123:8(753)

Christensen PB, Sørensen J (1986) Temporal variation of denitrification activity in plantcovered, littoral sediment from Lake Hampen, Denmark. Appl Environ Microbiol 51(6): 11741179

Comings KJ, Booth DB, Horner RR (2000) Storm water pollutant removal by two wet ponds in Bellevue, Washington. J Environ Eng 126(4): 321-330. doi:10.1061/(ASCE)07339372(2000)126:4(321)

Crossman J, Catherine Eimers M, Casson NJ, Burns DA, Campbell JL, Likens GE et al (2016) Regional meteorological drivers and long term trends of winter-spring nitrate dynamics across watersheds in northeastern North America. Biogeochemistry, 130(3), 247-265.

doi:10.1007/s10533-016-0255-z

Daniels WM, House WA, Rae JE, Parker A (2000) The distribution of micro-organic contaminants in river bed-sediment cores. Sci Total Environ 253(1):81-92. doi:10.1016/S00489697(00)00379-X

Davis AP, McCuen RH (2005) Stormwater management for smart growth. Springer Science

Davis AP, Shokouhian M, Ni S (2001) Loading estimates of lead, copper, cadmium, and zinc in urban runoff from specific sources. Chemosphere 44(5):997-1009. doi:10.1016/S00456535(00)00561-0

Dawson EJ, Macklin MG (1998) Speciation of heavy metals in floodplain and flood sediments: A reconnaissance survey of the Aire Valley, West Yorkshire, Great Britain. Environ Geochem Health 20(2):67-76. doi:10.1023/A:1006541724394

Debo TN, Reese AJ (1995) Municipal storm water management. Lewis Publishers.

Drake J, Guo Y (2008) Maintenance of wet stormwater ponds in Ontario. Can Water Resour J 33(4):351-368. doi:10.4296/cwrj3304351 
Durand C, Ruban V, Amblès A, Oudot J (2004) Characterization of the organic matter of sludge: Determination of lipids, hydrocarbons and PAHs from road retention/infiltration ponds in France. Environ Pollut 132(3):375-384. doi:10.1016/j.envpol.2004.05.038

Edmondson WT (1970) Phosphorus, nitrogen, and algae in Lake Washington after diversion of sewage. Science, 169(3946):690-691. doi:10.1126/science.169.3946.690

Egemose S, Sønderup MJ, Grudinina A, Hansen AS, Flindt MR (2015) Heavy metal composition in stormwater and retention in ponds dependent on pond age, design and catchment type. Environ Technol 36(8):959-969. doi:10.1080/09593330.2014.970584

Einsele W (1936) Ueber die Beziehungen des Eisenkreislaufs zum Phosphatekreislauf im eutrophen See. Arch Hydriobiol 29: 664-686.

Einsele W (1938) Ueber chemische und kolloidchemische Vorgänge in Eisen-Phosphate Systemen unter limnochemischen und limnogeologischen Gesichtspunkten. Arch Hydrobiol 33: 361-387.

Ekholm P, Malve O, Kirkkala T (1997) Internal and external loading as regulators of nutrient concentrations in the agriculturally loaded Lake Pyhäjärvi (southwest Finland). Hydrobiologia 345(1):3-14. doi:10.1023/A:1002958727707

El-Mufleh A, Béchet B, Basile-Doelsch I, Geffroy-Rodier C, Gaudin A, Ruban V (2014) Distribution of PAHs and trace metals in urban stormwater sediments: Combination of density fractionation, mineralogy and microanalysis. Environ Sci Pollut Res 21(16):9764-9776. doi:10.1007/s11356-014-2850-7

Elser JJ, Kimmel BL (1985) Nutrient Availability for Phytoplankton Production in a MultipleImpoundment Series. Can J Fish Aquat Sci 42(8): 1359-1370. doi:10.1139/f85-171

Elser JJ, Bracken MES, Cleland EE, Gruner DS, Harpole WS, Hillebrand H, Smith JE et al (2007) Global analysis of nitrogen and phosphorus limitation of primary producers in freshwater, marine and terrestrial ecosystems. Ecol Lett 10(12):1135-1142. doi:10.1111/j.14610248.2007.01113.x

Ferguson BK (1991) Taking advantage of stormwater control basins in urban landscapes. J Soil Water Conserv 46(2):100-103.

Foley JA, DeFries R, Asner GP, Barford C, Bonan G, Carpenter SR, Snyder PK et al (2005) Global consequences of land use. Science 309(5734):570-574. doi:10.1126/science.1111772

Gächter R, Müller B (2003) Why the phosphorus retention of lakes does not necessarily depend on the oxygen supply to their sediment surface. Limnol Oceanogr 48(2): 929-933.

doi:10.4319/1o.2003.48.2.0929 
Goldman CR (1981) Lake Tahoe: two decades of change in a nitrogen deficient oligotrophic lake. Verh Int Verein Limnol 21:45-70

Golterman HL (2001) Phosphate release from anoxic sediments or 'What did mortimer really write? Hydrobiologia 450(1):99-106. doi:10.1023/A:1017559903404

Golterman HL (2004) The chemistry of phosphate and nitrogen compounds in sediments. Dordrecht: Kluwer Academic.

Graham EI, Lei JH (2000) Stormwater management ponds and wetlands sediment maintenance. Water Qual Res J Canada 35(3):525-539.

Hamilton RS, Revitt DM, Warren RS (1984) Levels and physico-chemical associations of cd, cu, $\mathrm{pb}$ and $\mathrm{zn}$ in road sediments. Sci Total Environ 33(1): 59-74. doi:10.1016/0048-9697(84)90381-4

Haritash AK, Kaushik CP (2009) Biodegradation aspects of polycyclic aromatic hydrocarbons (PAHs): A review. J Hazard Mater 169(1):1-15. doi:10.1016/j.jhazmat.2009.03.137

He C, Marsalek J (2014) Enhancing sedimentation and trapping sediment with a bottom grid structure. J Environ Eng 140(1):21-29. doi:10.1061/(ASCE)EE.1943-7870.0000774

Hobbie SE, Finlay JC, Janke BD, Nidzgorski DA, Millet DB, Baker LA (2017) Contrasting nitrogen and phosphorus budgets in urban watersheds and implications for managing urban water pollution. Proc Natl Acad Sci USA 14(16):4177-4182. doi:10.1073/pnas.1618536114

Howard PJA, Howard DM (1990) Use of organic carbon and loss-on-ignition to estimate soil organic matter in different soil types and horizons. Biol Fertil Soils 9(4):306-310. doi:10.1007/BF00634106

Howarth RW, Cole JJ (1985) Molybdenum availability, nitrogen limitation, and phytoplankton growth in natural waters. Science 229(4714):653-655. doi:10.1126/science.229.4714.653

Jeppesen E, Jensen JP, Søndergaard M, Lauridsen T, Pedersen LJ, Jensen L (1997) Top-down control in freshwater lakes: The role of nutrient state, submerged macrophytes and water depth. Hydrobiologia 342:151-164. doi:10.1023/A:1017046130329

Juday C, Birge EA, Kemmerer GI, Robinson RJ (1927) Phosphorus content of lake waters in northeastern Wisconsin. Wis Acad Sci Arts Lett 23:233-248.

Kappler A, Straub KL (2005) Geomicrobiological cycling of iron. Reviews in Mineralogy and Geochemistry 59(1):85-108. doi:10.2138/rmg.2005.59.5

Karlsson K, German J, Viklander M (2010) Stormwater pond sediments: Temporal trends in heavy metal concentrations and sediment removal. Soil Sediment Contam 19(2):217-230. doi: $10.1080 / 15320380903548490$ 
Kojima K, Murakami M, Yoshimizu C, Tayasu I, Nagata T, Furumai H (2011) Evaluation of surface runoff and road dust as sources of nitrogen using nitrate isotopic composition. Chemosphere 84(11):1716-1722. doi:10.1016/j.chemosphere.2011.04.071

Kramer DL (1987) Dissolved oxygen and fish behavior. Env Biol Fish 18(2):81-92.

Kronvang B, Laubel A, Larsen SE, Friberg N (2003) Pesticides and heavy metals in Danish streambed sediment. Hydrobiologia 494(1):93-101. doi:10.1023/A:1025441610434

Lazaro TR (1990) Urban hydrology: a multidisciplinary perspective. Technomic, Lancaster

Ledford SH, Lautz LK, Vidon PG, Stella JC (2017) Impact of seasonal changes in stream metabolism on nitrate concentrations in an urban stream. Biogeochemistry 133(3):317. doi:10.1007/s10533-017-0336-7

Lee P, Touray J, Baillif P, Ildefonse J (1997) Heavy metal contamination of settling particles in a retention pond along the A-71 motorway in Sologne, France. Sci Total Environ 201(1):1-15. doi:10.1016/S0048-9697(97)84048-X

Leopold LB (1968) Hydrology for Urban Land Planning - A guide on the Hydrologic Effects of Urban Land Use. US Geological Survey

LeVeen EP, Willey WRZ (1983) A political economic analysis of urban pest management. In: Urban Entomology: Interdisciplinary Perspectives (1983), Frankie GW, Koehler CS, pp 19-40

Liikanen A, Murtoniemi T, Tanskanen H, Väisänen T, Martikainen, P (2002) Effects of temperature and oxygen availability on greenhouse gas and nutrient dynamics in sediment of a eutrophic mid-boreal lake. Biogeochemistry 59(3):269-286. doi:10.1023/A:1016015526712

Makepeace DK, Smith DW, Stephen JS (1995) Urban stormwater quality: Summary of contaminant data. Crit Rev Environ Sci Technol 25(2):93-139. doi:10.1080/10643389509388476

Mallin MA, Ensign SH, Wheeler TL, Mayes, D. B. (2002) Pollutant removal efficacy of three wet detention ponds. Journal of Environmental Quality 31(2):654. doi:10.2134/jeq2002.0654

Maloney TE, Miller WE, Shiroyama T (1972) Algal response to nutrient addition in natural waters. I. Laboratory assays. In: Nutrients and Eutrophication: The Limiting Nutrient Controversy (Proceedings of Symposia) (edited by G. E. Likens). Am. Soc. Limnol. Oceanogr. Spec. Symp. 1:134-140.

Marsalek J, Marsalek P (1997) Characteristics of sediments from a stormwater management pond. Wat Sci Tech 36(8-9):117-122. doi:10.1016/S0273-1223(97)00610-0

Marsalek J, Watt WE, Henry D (1992) Retrofitting stormwater ponds for water quality control. Water Poll Res J Canada 27(2):403-422 
Matthews KR, Berg NH (1997) Rainbow trout responses to water temperature and dissolved oxygen stress in two southern california stream pools. J Fish Biol 50(1), 50-67.

doi:10.1111/j.1095-8649.1997.tb01339.x

Mattraw HC, Hardee J, Miller RA (1978) Urban Stormwater Runoff Data for a Residential Area, Pompano Beach, Florida. US Geological Survey

Mayer T, Marsalek J, \& Reyes ED (1996) Nutrients and metal contaminants status of urban stormwater ponds. Lake Reserv Manag 12(3):348-363. doi:10.1080/07438149609354276

McCuen RH, Walesh SG, Rawls WJ (1983) Control of urban stormwater runoff by detention and retention. United States Department of Agriculture

McEnroe NA, Buttle JM, Marsalek J, Pick FR, Xenopoulos MA, Frost PC (2013) Thermal and chemical stratification of urban ponds: Are they 'completely mixed reactors'? Urban Ecosyst 16(2):327-339. doi:10.1007/s11252-012-0258-z

Miguntanna NP, Liu A, Egodawatta P, Goonetilleke A (2013) Characterising nutrients wash-off for effective urban stormwater treatment design. J Environ Manage 120:61-67. doi:10.1016/j.jenvman.2013.02.027

Moore PA, Reddy KR, Graetz DA (1992) Nutrient transformations in sediments as influenced by oxygen supply. J Environ Qual 21:387-393.

Mortimer CH (1942) The exchange of dissolved substances between mud and water in lakes. J Ecol 30(1):147-201. doi:10.2307/2256691

Mortimer CH (1981) The oxygen content of air-saturated fresh waters over ranges of temperature and atmospheric pressure of limnological interest. Mitteilungen der IVL 22.

Murphy J, Riley JP (1962) A modified single solution method for the determination of phosphate in natural waters. Anal Chim Acta 27:31-36. doi:10.1016/S0003-2670(00)88444-5

Ngabe B, Bidleman TF, Scott GI (2000) Polycyclic aromatic hydrocarbons in storm runoff from urban and coastal south carolina. Sci Total Environ 255(1):1-9. doi:10.1016/S00489697(00)00422-8

Novotny V, Sung H, Bannerman R, Baum K (1985) Estimating nonpoint pollution from small urban watersheds. J Water Pollut Control Fed 57(4):339-348.

Ontario Ministry of Environment and Energy (1994). Water Management Policies, Guidelines, Provincial Water Quality Objectives.

Ontario Ministry of the Environment (2003) Stormwater management planning and design manual Ontario Ministry of the Environment. 
Paul MJ, Meyer JL (2001) Streams in the Urban Landscape. Annual Review of Ecology and Systematics, 32(2001), 333-365.

Persson J (2000) The hydraulic performance of ponds of various layouts. Urban Water, 2(3):243250. doi:10.1016/S1462-0758(00)00059-5

Preisendorfe RW(1986) Secchi disk science: Visual optics of natural waters. Limnol Oceanogr 31(5):909-926

Reynolds WW, Thomson DA (1974) Responses of young gulf grunion, leuresthes sardina, to gradients of temperature, light, turbulence and oxygen. Copeia, 1974(3), 747-758.

Russell MA, Walling DE, Webb BW, Bearne R (1998) The composition of nutrient fluxes from contrasting UK river basins. Hydrol Process 12(9), 1461-1482. doi:10.1002/(SICI)10991085(199807)12:9<1461::AID-HYP650>3.0.CO;2-6

Rysgaard S, Risgaard-Petersen N, Sloth, NP, Jensen K, Nielsen LP (1994) Oxygen regulation of nitrification and denitrification in sediments. Limnol Oceanogr 39(7):1643-1652.

doi:10.4319/lo.1994.39.7.1643

Schindler DW (1974) Eutrophication and recovery in experimental lakes: Implications for lake management. Science 184(4139):897-899. doi:10.1126/science.184.4139.897

Schwartz D, Sample DJ, Grizzard TJ (2017) Evaluating the performance of a retrofitted stormwater wet pond for treatment of urban runoff. Environ Monit Assess 189(6):1. doi:10.1007/s10661-017-5930-6

Sharma B, Ahlert RC (1977) Nitrification and nitrogen removal. Water Res 11(10): 897-925. doi:10.1016/0043-1354(77)90078-1

Søberg LC, Vollertsen J, Blecken G, Nielsen AH, Viklander M (2016) Bioaccumulation of heavy metals in two wet retention ponds. Urban Water Journal 13(7):697-709.

doi:10.1080/1573062X.2015.1024689

Solórzano L (1969) Determination of ammonia in natural waters by the phenolhypochlorite method. Limnol Oceanogr 14(5):799-801

Sønderup MJ, Egemose S, Hansen AS, Grudinina A, Madsen MH, Flindt MR (2016) Factors affecting retention of nutrients and organic matter in stormwater ponds. Ecohydrology 9(5):796806. doi:10.1002/eco.1683

Song K, Xenopoulos MA, Buttle JM, Marsalek J, Wagner ND, Pick FR, Frost, P. C (2013) Thermal stratification patterns in urban ponds and their relationships with vertical nutrient gradients. Journal of Environmental Management 127:317. doi:10.1016/j.jenvman.2013.05.052 
Song K, Winters C, Xenopoulos MA, Marsalek J, Frost PC (2017) Phosphorus cycling in urban aquatic ecosystems: Connecting biological processes and water chemistry to sediment $\mathrm{P}$ fractions in urban stormwater management ponds. Biogeochemistry 132(1): 203-212. doi:10.1007/s10533017-0293-1

Stanley DW (1996) Pollutant removal by a stormwater dry detention pond. Water Environ Res 68(6):1076-1083. doi:10.2175/106143096X128072

Stumm W \& Morgan J J (1996) Aquatic chemistry: Chemical equilibria and rates in natural waters (3rd ed.) Wiley

Szmytkiewicz A, Zalewska T (2014) Sediment deposition and accumulation rates determined by sediment trap and ${ }^{210} \mathrm{~Pb}$ isotope methods in the Outer Puck Bay (Baltic Sea). Oceanologia 56(1): 85-106. doi:10.5697/oc.56-1.085

Tai YL (1991) Physical and Chemical Characterisation of street dust and dirt from urban area. (Vol. 93). Department of Civil Engineering, Pennsylvania State University.

Toronto Water (2009) Design criteria for sewers and watermains.

Trenberth KE (2011) Changes in precipitation with climate change. Clim Res 47:123-138. doi:10.3354/cr00953

United Nations (2014) World Urbanization Prospects: The 2014 Revision, Highlights. New York, United States.

United States Environmental Protection Agency (1983) Results of Nationwide Urban Runoff Program (Vol. 1).

US Geological Survey (1999) The Quality of Our Nation's Waters- Nutrients and Pesticides. US Geological Survey Circular 1225.

Vollenweider RA (1968) Scientific Fundamentals of the Eutrophication of Lakes and Flowing Waters, with Particular Reference to Nitrogen and Phosphorus as Factors in Eutrophication. Organisation for Economic Co-Operation and Development.

Vollenweider RA (1975) Input-output models: With special reference to the phosphorus loading concept in limnology. Schweizerische Zeitschrift Für Hydrologie, 37(1):53-84. doi:10.1007/BF02505178

Wanielista M, Yousef YA, Taylor J (1982) Stormwater management to improve lake water quality. Environ Protection Agency Report, 600/82-82-048, Washington, D.C.

Waschbusch RJ, Selbig WR, Bannerman RT (1999) Sources of phosphorus in stormwater and street dirt from two urban residential basins in Madison, Wisconsin, 1994-95. U.S. Geological Survey Water Resources Investigation Report 99-4021. 
Weiss PT, Gulliver JS, Erickson AJ (2007) Cost and pollutant removal of storm-water treatment practices. Journal of Water Resources Planning and Management 133(3):218-229. doi:10.1061/(ASCE)0733-9496(2007)133:3(218)

Welch EB, Cooke GD (2005) Internal phosphorus loading in shallow lakes: Importance and control. Lake Reserv Manage 21(2):209-217. doi:10.1080/07438140509354430

Weston DP, Holmes RW, Lydy MJ (2009) Residential runoff as a source of pyrethroid pesticides to urban creeks. Environ Pollut 157(1):287-294. doi:10.1016/j.envpol.2008.06.037

Wetzel RD (2001) Limnology: Lake and river ecosystems. San Diego: Academic Press.

Wetzel RG, \& Likens GE (2000) Limnological analyses (3rd ed.) Springer.

Whipple W, Kropp R, Burke S (1987) Implementing dual-purpose stormwater detention programs. J Water Resour Plann Manage 113(6):779-792

Winston RJ, Hunt WF, Kennedy SG, Merriman LS, Chandler J, Brown D (2013) Evaluation of floating treatment wetlands as retrofits to existing stormwater retention ponds. Ecological Engineering 54:254-265. doi:10.1016/j.ecoleng.2013.01.023

Wood ED, Armstrong FAJ, Richards FA (1976) Determination of nitrate in sea water by cadmium-copper reduction to nitrite. J Mar Biol Assoc U.K. 47(1):23-31

Wu JS, Holman RE, Dorney JR (1996) Systematic evaluation of pollutant removal by urban wet detention ponds. J Environ Eng 122(11):983-988. doi:10.1061/(ASCE)0733-

9372(1996)122:11(983)

Wurtsbaugh WA (1988) Iron, molybdenum and phosphorus limitation of N2 fixation maintains nitrogen deficiency of plankton in the Great Salt Lake drainage (Utah, USA). Verh Int Ver Limnol 23:121-130.

Yoshimura, T, Nishioka, J, Saito, H, Takeda, S, Tsuda, A, Wells, ML (2007) Distributions of particulate and dissolved organic and inorganic phosphorus in north pacific surface waters. Marine Chemistry 103(1):112-121. doi:10.1016/j.marchem.2006.06.011

Yousef YA, Hvitved-Jacobsen T, Sloat, J, Lindeman W (1994) Sediment accumulation in detention or retention ponds. Sci.Total Environ 146:451-456. doi:10.1016/0048-9697(94)902682

Zoppou C (2001) Review of urban storm water models Elsevier Ltd. doi:10.1016/S13648152(00)00084-0 